\title{
KEMO-HIDRODINAMIKAI INSTABILITÁSOK VIZSGÁLATA MIKROGRAVITÁCIÓBAN
}

Doktori (Ph.D.) értekezés

\author{
BÁBA PÉTER
}

Témavezetô: Dr. Horváth Dezső

egyetemi tanár

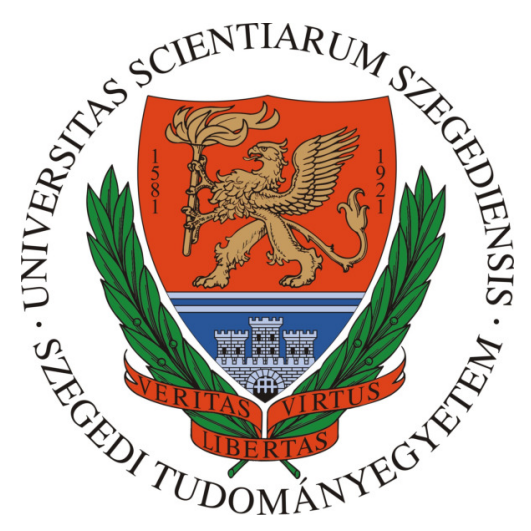

Környezettudományi Doktori Iskola

Fizikai Kémiai és Anyagtudományi Tanszék

Természettudományi és Informatikai Kar

Szegedi Tudományegyetem

Szeged, 2019 


\section{Tartalomjegyzék}

$\begin{array}{ll}\text { 1. Bevezetés } & 3\end{array}$

2. Irodalmi áttekintés 6

2.1. Hidrodinamikai instabilitás . . . . . . . . . . . . . . 6

2.1.1. Rayleigh-Taylor-instabilitás . . . . . . . . . . . . . 7

2.1.2. Marangoni-instabilitás . . . . . . . . . . . . . . 9 9

2.1.3. Kemo-hidrodinamikai instabilitás . . . . . . . . . . . 10

2.2. Jodátion-arzénessav reakció f . . . . . . . . . . . . . . . 12

2.3. Mikrogravitáció . . . . . . . . . . . . . . . 16

3. Célkitüzés 21

4. Kísérleti módszerek és eszközök 22

4.1. Parabolarepülés . . . . . . . . . . . . . . . . . . 22

4.2. Szuborbitális rakéta . . . . . . . . . . . . . . . . . 24

5. Kiértékelési módszerek 28

5.1. Frontalak, frontsebesség meghatározása . . . . . . . . . . . 28

5.2. Sebességmeghatározás a folyadékban . . . . . . . . . . . . 30

6. Numerikus modellezés 36

7. Eredmények 45

7.1. Modulált gravitációs erôtér hatása . . . . . . . . . . . . 45

7.2. Földi referenciamérések eredményei . . . . . . . . . . . . . . 48

7.3. Mikrogravitációban elvégzett mérések eredményei . . . . . . . . . 51

7.4. Numerikus szimulációk eredményei . . . . . . . . . . . . . . 62

8. Összefoglalás $\quad 70$

$\begin{array}{ll}\text { 9. Summary } & 73\end{array}$

$\begin{array}{ll}\text { Irodalomjegyzék } & \mathbf{7 6}\end{array}$

$\begin{array}{lll}\text { Mellékletek } & 82\end{array}$

Köszönetnyilvánítás $\quad 90$ 


\section{Bevezetés}

A transzportfolyamatok életünk számos területére vannak jelentős hatással. Ezen folyamatok segítségével jön létre ugyanis az anyag, energia, impulzus, illetve töltések térbeli áramlása intenzív mennyiségekben kialakult gradiens hatására. Az élet keletkezésének folyamata sok kutató vizsgálódásainak középpontjában áll. A klasszikus Miller-Urey-kísérletben például a Föld életének korai szakaszában jellemző körülményeket modellezve, néhány szervetlen vegyület reakciójából sikerült aminosavakat előállítani [1]. Az aminosavak később fehérjék alapkövei, mely fehérjék az élő szervezetek számára alapvető fontosságúak. Belátható, hogy az élet kialakulásához megfelelő körülmények között lejátszódó kémiai reakciókra volt szükség. Azonban ezen reakciók lejátszódásához a megfelelő körülmények mellett elengedhetetlen, hogy a reaktánsok térben és idôben is ugyanazon helyen rendelkezésre álljanak, ezt pedig a transzportfolyamatok biztosítják. Az emberi szervezet alapvetô életfolyamatai az anyagcsere-folyamatok, melyek szintén transzportjelenségek. A szív- és érrendszerben a szív nyomáskülönbséget alakít ki, melynek hatására véráramlás indukálódik. A vérben

mint szállító közegben az oldott tápanyagok és nyomelemek mellett szén-dioxid és oxigén advektív transzportja történik a sejtekhez. A szén-dioxid oxigénre történő cseréje például a tüdő alveolusaiban megy végbe. Az alveolusokban egy membrán két oldalán oxigén és szén-dioxid koncentrációgradiens (parciális nyomásgradiens) alakul ki. A gradiens hatására a molekulák tisztán diffúzió révén jutnak be a vérbe. A gradiens a két molekula esetén ellentétes irányú, így az oxigén a tüdőből a vérbe, a szén-dioxid a vérből a tüdőbe áramlik. Ez természetesen nagyfokú leegyszerúsítése egy igen komplex folyamatnak. Az emberi szervezetben megtalálható transzportfolyamatok száma olyan nagy, hogy leírásuk több doktori disszertáció terjedelmét is meghaladná.

Környezetünkben mindennapi életünket meghatározó folyamatokban is kulcsszerepet játszanak ezek a folyamatok. Gondoljunk az időjárási jelenségekre. A Föld felszíne a beérkező sugárzást infravörös sugárzássá alakítja felmelegítve ezáltal a felszín közeli légrétegeket. A hőmérsékletgradiens miatt kialakuló nyomásgradiens konvektív áramlást indukálva vízpárát szállít a magasabb légrétegekbe, ahol telítődés esetén a vízpára kondenzálódik. Ez a felhôképződés alapja. A felhőket a vízszintes nyomásgradiens hatására kialakuló légmozgás szállítja más területek fölé, ahol a vízcseppek egyesülése esetén csapadék formájában visszajutnak a felszínre, egyik fontos lépcsőjét alkotva ezzel a víz körforgásának. A globális hômérsékleteloszlást - és ezáltal a lokális időjárási jelenségeket is - befolyásoló jóval nagyobb léptékú jelenség az úgynevezett termohalin cirkuláció, mely a felszíni légmozgás mellett sưrűségkülönbség hatására indukált áramlása a világtengerek vizének. A sûrúségkülönbséget a víz hőmérséklete és annak sókoncentrációja együttesen határozza meg. Ilyen eredetú áramlás például a Golf-áramlat, mely nagy mennyiségú hőt szállít döntôen meghatá- 


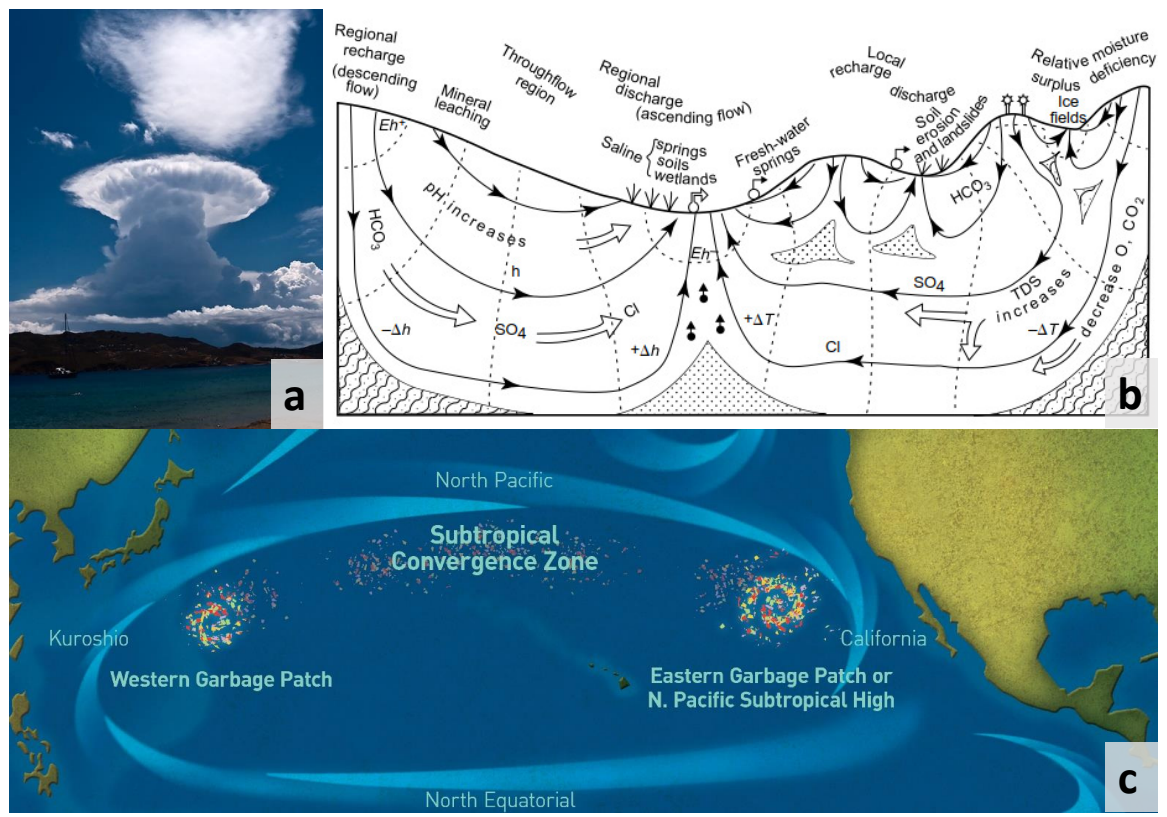

1.1. ábra. Különböző transzportjelenségek a természetben: felhőképződés (a) [6], felszín alatti vízáramlás és a hozzákapcsolódó jelenségek (b) [4], az óceán felszínén kialakult „,szemétszigetek" pozíciója (c) [6].

rozva ezzel Európa nagy részének klímáját [2].

Sajnos az emberi jelenléttel a környezetet terhelő hatások is megjelentek a Földön. Az említett óceáni áramlatok a nagy mennyiségú hô mellett egyre nagyobb mennyiségú múanyag hulladékot is szállítanak, melynek csupán mennyiségi felmérése is napjaink egyik legnagyobb kihívását jelenti [3]. Azonban az ilyen, szemmel jól látható szennyezések mellett vannak olyan környezeti terhelések, melyek rejtve maradnak az emberi szem elól. Például a földfelszín alatt terjedő szennyezések, melyek hordozó közege a talajvíz, révén hogy a víz az egyik legkiválóbb oldószer környezetünkben. Az ilyen módon szállított szennyezések azonban ivóvízkészleteinket veszélyeztetik. Ahhoz, hogy megóvjuk ezeket a készleteket először a víz áramlását kell tudnunk leírnunk és modelleznünk. A magyar származású de Kanadában kutató Tóth József egy olyan egyszerú elméletet alkotott mellyel a felszín alatti víz mozgása jól leírható és számos geológiai folyamat is kiválóan magyarázható [4]. Hasonlóan nagy kockázatot rejtenek a kizárólag a mérőmúszerek számára látható radioaktív szennyezések, melyek a légkörbe jutva néhány hét alatt a forrástól a Föld legtávolabbi részére is eljuthatnak. Az ilyen, komplex módon terjedő, nehezen észlelhető szennyezések esetén hatékony védekezés csak akkor lehetséges, ha ismerjük a terjedésüket befolyásoló áramlásokat, ezért ezek leírására is nagy erőfeszítéseket tesznek [5].

Szennyezőanyagok terjedését összetett mechanizmusok határozzák meg, melyekhez gyakran a transzport közben lejátszódó reakciókat is figyelembe kell venni. Ezek nélkül nem jósolható pontosan azok koncentrációja. Hasonlóan bonyolult mechanizmussal rendelkeznek 
a reakció-diffúzió-advekció rendszerek is. Ezekben az egyensúlytól távoli rendszerekben, az advektív transzport mellett a reakciók és a diffúzió egymásra hatása is befolyásolja a specieszek koncentrációját. A mechanizmusra jellemző a reakció és a transzportfolyamatok kölcsönhatásából kialakuló térbeli mintázatok megjelenése. Ezek közül a legegyszerúbbek autokatalitikus reakció estén kialakuló kémiai frontok, melyek éles határvonalként választják el a reaktánsokat a terméktől. A reakciófront tehát egy reaktív határfelület, mely mentén anyagátalakulás megy végbe és amely emiatt két eltérô fizikai tulajdonságokkal rendelkező folyadékrészt választ el egymástól. Az eltérő fizikai tulajdonságokból keletkező gradiensek miatt bizonyos orientációban haladó front stabilitását veszti és folyadékáramlás indukálódik, mely hatással van a reakciófront tulajdonságaira. Munkám során a súrúségkülönbségből adódó Rayleigh-Taylor és a felületi feszültségkülönbségből adódó Marangoni-instabilitás által indukált folyadékáramlásokat vizsgáltam egy ilyen autokatalitikus frontreakcióban. A két jelenség hatásaként beinduló áramlások Földi körülmények között nehezen vizsgálhatók, ugyanis együttesen jelentkeznek és az előbbi jóval nagyobb áramlásokat indukálva elfedi a Marangoni-instabilitásból keletkező folyadékmozgást. Azonban az Európai Ürügynökség támogatásával olyan körülmények között végezhettem kísérleteket, mely lehetőséget biztosít a Rayleigh-Taylor-instabilitás hatásának kiküszöbölésére. Mikrogravitációban elvégzett mérések során a nehézségi erô nagyságrendekkel csökkenthetô, így a hidrosztatikai nyomáskülönbség megszúnik a reakciófront két oldalán elhelyezkedő folyadékrész között. Az ily módon kapott eredményeket reprodukáltam egy univerzálisan alkalmazható reakciódiffúzió-advekció modell felállításával. Segítségével mind a Rayleigh-Taylor- mind pedig a Marangoni-instabilitás által keltett folyadékáramlás vizsgálható olyan kémiai rendszerekben, ahol rendelkezésre állnak a reakciómechanizmust leíró egyenletek és azok empirikus sebességi együtthatói. 


\section{Irodalmi áttekintés}

\subsection{Hidrodinamikai instabilitás}

Transzportfolyamatok során extenzív mennyiség áramlása történik a tér két pontja között. Az áramlás kialakulásának alapvető feltétele egy intenzív mennyiség inhomogén térbeli eloszlása. Fluidumokban az ilyen mennyiségekben kialakuló gradiensek mentén mozdulnak el a részecskék homogén eloszlás kialakítására törekedve. Az áramlatok stabilitását a bennük kialakult áramkép állandósága tükrözi. A természetben számos esetben figyeltek meg kezdetben állandó áramképpel rendelkező stabil áramlásokban vagy nyugvó folyadékokban megjelenő örvénylő komplex áramképek kialakulását. Ezek a jelenségek különösen gyakoriak folyadék-gáz vagy eltérô fizikai tulajdonságokkal rendelkező folyadékokat elválasztó folyadék-folyadék határfelületeken. A hidrodinamikailag stabil rétegződés vagy áramlás jellemzője, hogy amennyiben a határfelületeken kis perturbációt hozunk létre, akkor olyan mozgások indukálódnak, amelyek ezt a zavart kioltják. Instabil elrendezés esetén a perturbáció tovább növekszik és komplex, esetenként örvénylő mozgás alakul ki. Egyszerú esetekben kialakuló instabilitás a turbulencia. Ilyenkor a rendszer stabilitását az áramlási geometria, az áramlási sebesség és a fluidum tulajdonságai együttesen határozzák meg. Ezek a mennyiségek jelennek meg a jól ismert Reynolds-számban is. Reynolds kimutatta, hogy a kaotikus örvénylő áramlás adott rendszerben az áramlási sebességtől függôen alakul ki [7]. Rávilágított arra is, hogy ugyanabban a rendszerben a hômérséklet növelésével az instabilitás megjelenése nagyobb sebességértéknél jelentkezik. Az áramló folyadékban mindig jelen vannak kis perturbációk, melyek származhatnak a folyadék inhomogenitásából vagy csőben történő áramlás esetén a cső rezgéséből, illetve a csőfal egyenetlenségéből. Küszöbérték alatti áramlási sebesség esetén ezeket a kis inhomogenitásokat a folyadék viszkozitása kiegyenlíti. Adott áramlási sebesség felett azonban a kiegyenlítődés helyett éppen felerősödés tapasztalható, mely kaotikus áramlást hoz létre. Ez igen nagy leegyszerúsítése a jelenségnek, teljes részletességgel való leírása a jelenkor egyik legnagyobb tudományos kihívása.

A folyadék-gáz határfelülettel rendelkező nem áramló rétegzett rendszerekben a hőmérséklet-, a sûrúség- és a felületi feszültség-inhomogenitás kelthet folyadékáramlást. Előbbit Henri Bénard mutatta ki kísérleteiben [8]. Az alulról fütött vékony olajrétegben kialakuló cellás szerkezetet figyelt meg a folyadék-levegő határfelületen. A szerkezet az inhomogén hőmérsékleteloszlás hatására bekövetkező szabályos mintázatú folyadékáramlás miatt alakul ki. A hatszögletú cellák közepén feláramlás, a szélein pedig leáramlás a jellemzô. A felületnek szerepe ebben az esetben a hőleadásban van. A cellák közepén feláramló melegebb folyadék a felszínt elérve lehúl majd az élek mentén visszasüllyed. Bénard azt is észrevette, hogy a hatszögletû elemek közepén a folyadékréteg bemélyed, míg a cellák szé- 
lein kissé felfelé tér el a sík felülettől. Azt is azonosította, hogy a felület deformációjában a hőmérséklettel változó felületi feszültségnek van szerepe [9]. Az 1950-es években Block kísérleteiben kissé túlértékelve mutatta be a felületi feszültség jelentőségét, míg Pearson az elméletét részletezte ugyanennek a rendszernek [10,11]. A hatvanas évek közepén Nield tisztázta, hogy a felületi feszültség és a súrúségváltozás együttesen hozzák létre a kialakuló mintázatot [12]. A hőmérséklet-különbség miatt kialakuló instabil sưrû́ségrétegződést Rayleigh-Bénard-instabilitásnak nevezzük, mely fedett, folyadék-gáz határfelület nélküli folyadékrétegben is megfigyelhetô. A jelenségnek kulcsszerepe van a Nap fotoszférájában felfedezett mintázatok létrejöttében, illetve számos meteorológiai és geofizikai folyamatban, melyet maga Bénard is igen korán megállapított [13]. Az inhomogén hőmérsékleteloszlású szabad felszínen, a felületi feszültség gradiensében kialakuló különbségek hatására pedig, az úgynevezett Bénard-Marangoni-instabilitás jön létre.

Szintén határfelületen kialakuló instabilitás, a Saffman-Taylor-instabilitás. Ez olyan esetekben figyelhetô meg, amikor egy nagyobb viszkozitású folyadékba nyomunk egy kisebb viszkozitású folyadékot porózus közegben vagy az azt modellező Hele-Shaw edényben [14]. A két folyadék között kezdetben zavarmentes határfelület elveszti stabilitását és ujjszerú elôre sietố részek jelennek meg. Az instabilitás hatására a kisebb viszkozitású folyadék nem kiszorítja a nagyobb viszkozitásút abból a térből ahová benyomul, hanem adott csatornákon átnyomul rajta. A jelenségre az irodalomban leggyakrabban a már említett Saffman-Taylorinstabilitás névvel hivatkoznak. Azonban Saffman és Taylor előtt Hills egy cukorfinomító eljárás során megfigyelt probléma vizsgálatakor már leírta [15]. Az olajiparban bevett gyakorlat, hogy vízbesajtolásával fokozzák az olajkinyerés hatékonyságát, ez az úgynevezett fokozott olajkinyerési (EOR) technológia. A technológia bevezetése során megfigyelték, hogy nem szabad bizonyos nyomás értéket meghaladva adagolni a vizet mert a hatékonyság gyakorlatilag nullára csökken. Ha kisebb viszkozitású folyadék nyomása adott érték fölé nô akkor a határfelületen stabilitásvesztés alakul ki és a víz kitüntetett pályákon átnyomul az olajon ahelyett, hogy kiszorítaná a porózus közegből [16]. Ugyanez a jelenség jellemző a napjainkban intenzíven kutatott folyamat - a szén-dioxid felszín alá történő besajtolásakor [17]. Hasonlóan negatív hatás jelentkezik kromatográfiás elválasztás során, ha a minta és az eluens között nagy viszkozitáskülönbség áll fenn [18,19].

\subsubsection{Rayleigh-Taylor-instabilitás}

Lord Rayleigh 1880-ban írta le az instabil és stabil rétegzettségú folyadékokat elválasztó határfelületek viselkedését. Megállapította, hogy instabil rétegződés esetén a felületen a $k$ hullámszámmal jellemzett perturbáció növekedésének mértéke $g$ nagyságú gyorsulási érték mellett 


$$
n=-\sqrt{k g \frac{\rho_{2}-\rho_{1}}{\rho_{2}+\rho_{1}}}=-\sqrt{k g A_{t}},
$$

ahol $\rho_{1}$ és $\rho_{2}$ rendre a kisebb, illetve nagyobb oldatsûrúség értékek, $A_{t}$ pedig az úgynevezett Atwood szám [20]. Taylor az 1950-es években vizsgálta két, egymásra rétegzett eltérő sűrűségú folyadékoszlop közötti határfelület viselkedését amennyiben az különböző mértékú a határfelületre merôleges irányú gyorsulásnak van kitéve [21]. Taylor elméleti munkáját Lewis egészítette ki víz és vele nem elegyedő különböző folyadékokkal képzett határfelületeket vizsgálva, különböző gyorsulási értékek mellett [22]. A kísérletek során a sûrűségkülönbség nem az eltérô hőmérsékletből hanem az eltérő anyagi minőségből adódott. Roberts és Jacobs egy nagyon szemléletes módon mutatja be, hogy miért indul be az áramlás instabil rétegződés esetén [23]. A 2.1 ábrán a stabil és instabil rétegződést szemléltetem. A folyadékoszlopban nyomásgradiens irányát a $\vec{a}$ iránya határozza meg. Gravitációs körülmények között nyugvó folyadékoszlopban csupán hidrosztatikai nyomással kell számolni, a nyomásgradiens iránya pedig megegyezik $\vec{g}$ irányával. Stabil sűrúségrétegződés esetén a sûrűséggradiens lefelé mutat, instabil rétegződés esetén pedig felfelé. Az instabilitás feltétele ebben az esetben a $\nabla p \cdot \nabla \rho<0$. Azonban ez csak szükséges de nem elegendő feltétele az instabilitás kialakulásának. Szükség van még a határfelületen egy minimális perturbáció jelenlétére. Ugyanis amint kialakul egy minimális görbület, a sûrúség- és nyomásgradiens vektorok már nem egy vonalra esnek, így a görbület miatt $\omega$ forgatónyomaték keletkezik a határfelületen.

$$
\frac{D \omega}{D t} \approx \frac{1}{\rho^{2}} \nabla \rho \times \nabla p
$$

A forgatónyomaték a (2.2) egyenlet alapján a $\nabla \rho \times \nabla p$-vel arányos. Instabil rétegződés ese-
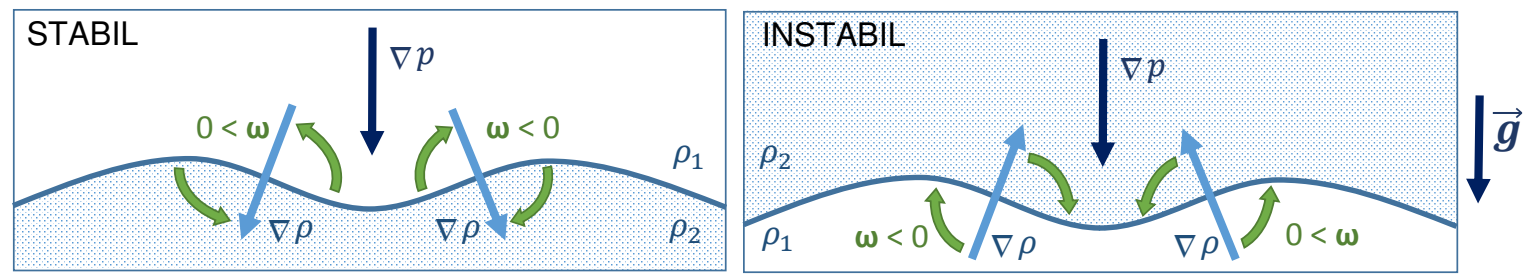

2.1. ábra. Rayleigh-Taylor instabilitás szemléletes ábrázolása. Mindkét esetben $\rho_{1}<\rho_{2}$.

tén ez a forgatónyomaték tovább növeli a $\nabla \rho$ és $\nabla p$ iránya közötti eltérést, mely további forgató nyomatékot generál. A meginduló folyadékáram hatására a kezdetben kis görbület nagysága folyamatosan növekszik. Stabil rétegződés esetén a keletkező forgatónyomaték olyan irányú, hogy a perturbációt kioltó folyadékmozgás indul meg. A jelenséget meteorológiában baroklin instabilitásnak nevezik és a felhőképződésben játszik nagy szerepet [24,25]. Az ilyen módon létrejövő fluidum áramlásnak számos területen van nagy jelentősége: az óceánokban a part menti sáv vizeit felfrissítő áramlások [26], és asztrofizikában a szupernóva- 
maradványok jellegzetes szerkezetének kialakulásában [27,28]. Kísérleti fúziós reaktorok egyik típusában viszont egy, a fúzió létrejöttét gátló folyamatért teszik felelőssé [23].

\subsubsection{Marangoni-instabilitás}

Fluidumok határfelületén (folyadék-folyadék vagy folyadék-gáz) a felületi feszültség-különbség okozta instabilitás hatására is folyadékáramlás indukálódik. Jó példa erre a „bor könnyei” névvel illetett jelenség, melynek folyamatát 1855-ben James Thomson írta le. Ennek alapja, hogy a borospohárban lényegében egy alkohol-víz elegy található, mely nedvesíti az üvegpohár falát. A falon felhúzódó vékony filmben az alkohol intenzívebb párolgása miatt az alkohol koncentrációja lecsökken. Ennek következtében megnő a felületi feszültség és még feljebb húzódik a film a pohár falán. A lokálisan megnövekedett felületi feszültség folyamatos folyadékáramlást tart fenn egyre több folyadékot juttatva a filmrétegbe. Egy idő után, amikor a folyadékréteg tömege elér egy kritikus értéket, a folyadék a gravitációs erő hatására visszafolyik a tömbfázisba. Ez az áramlás mindaddig fenn áll, amíg a folyadék teljes alkohol tartalma el nem párolog. 1865-ben Carlo Giuseppe Matteo Marangoni doktori értekezésében tanulmányozta a folyadék-gáz határfelületen a felületi feszültség különbség hatására indukálódó folyadékmozgásokat [29]. Megállapította, hogy a különbség a felületi feszültségben származhat inhomogén hômérsékleteloszlásból és inhomogén összetételeloszlásból is. A bor könnyei jelenség hajtóerejét sokáig kizárólag az inhomogén alkohol koncentrációeloszlással azonosították [30]. Nemrég azonban kimutatták, hogy a párolgás miatt fellépő lokális hőmérséklet gradiensnek is nagy szerepe lehet az áramlás kialakulásában [31]. De számos más érdekes folyamatban játszik még kulcsszerepet a Marangoniinstabilitás. Egy 1929-ben készült filmfelvételen a Nobel-díjas Irving Langmuir mutat be és magyaráz el részletesen több olyan kísérletet, amelyek folyadék-gáz, illetve folyadékfolyadék határfelületeken megfigyelhetô látványos jelenségeket szemléltetnek [32]. Többek között bemutatja, hogy egy „kámforhajó” elkészítéséhez egy kámfordarabkát kell helyezni a folyadékfelszínen lebegô papírhajó egyik végébe. A hajó ezután az oldódó kámfor felületi feszültséget csökkentő hatása miatt az ellentétes irányba megindul és végez rendezetlen mozgást. Különböző, a Marangoni-instabilitáshoz köthető oszcilláló folyadékmozgásokat is figyeltek már meg határfelületeken. Wodlei és társai diklórmetán-víz-tenzid rendszerben figyeltek meg pulzáló, forgó és rezgő mozgást végző cseppeket [33]. A szerves oldószer cseppek alacsony tenzidkoncentrációnál kisebb cseppek periodikus kilökődésévél oldódnak. A tenzid koncentrációjának növelésével a cseppek először vonal menti rezgő mozgást végeznek, úgy hogy a szélső helyzetben történik meg kisebb cseppek kilökődése. Később körtől eltérô alakot vesznek fel és az aszimmetria miatt forgó mozgásba kezdenek és a kisebb részletek egy spirál mentén válnak le a nagyobb oldatrészről.

Shutter és munkatársai szerves kétkomponensû túlhûlt oldatokból kiváló kristályok moz- 
gását írták le. A mozgás kiváltó okaként a nukleáció során, a megváltozott oldatösszetétel miatt kialakuló éles koncentrációgradienst jelölték meg, mely Marangoni-instabilitás kialakulásához vezet [34]. Szerves oldószerekben diszpergált részecskék esetén, a száradási folyamatokban, amikor az oldószer párolgása után csak a diszpergált részecskék maradnak hátra szilárd felületeken, a részecskék eloszlására gyakran jellemző inhomogenitás. Ezt az úgynevezett kávé-gyưrü - angolul „,coffee ring” - jelenségnek nevezik. Kezdetben nem tulajdonítottak nagy jelentôséget a felületi feszültség különbségnek a gyưrúk kialakításában [35]. Azonban késôbb mind numerikus számításokkal, mind kísérletileg kimutatták, hogy az oldószer párolgása során kialakuló felületi feszültség gradiens által keltett áramlásoknak jelentôs hatása van a részecskék eloszlására [36,37]. Azt is leírták, hogy vércseppek száradása során, a keletkező mintázatok kialakulásáért is a Marangoni-instabilitás a felelôs [38]. A mechanizmus megértésével búnügyi szakértôi feladatokban pontosabban tudják meghatározni, hogy egy-egy vérfolt kialakulását mekkora térfogatú vér okozta.

Marangoni-instabilitás nem csak az összetétel-változás hatására alakulhat ki, hanem hőmérsékletgradiens hatására is. S ôt a tudományos vizsgálatok jelentős része az ilyen körülmények között kialakuló áramlások vizsgálatára irányult. Félvezető kristályok előállítására irányuló technikák során jelentôs hőmérsékletgradiensek alakulnak ki. A fémolvadék felületi feszültségében a hőmérsékleteloszlás hatására szintén gradiens alakul ki, mely az olvadék áramlását idézi elő. Az ilyen áramlások a kristály tömbfázisába szennyeződéseket juttatnak, illetve inhomogenitásokat hoznak létre az anyagban, mely a félvezetô minőségét nagyban rontják [39].

\subsubsection{Kemo-hidrodinamikai instabilitás}

A kemo-hidrodinamikai instabilitás kialakulásáról olyan esetekben beszélünk, amikor az instabil rétegződést kémiai reakció hozza létre. Mivel a reakciók lejátszódása során anyagátalakulás megy végbe, a kiindulási anyag és a termék fizikai tulajdonságaikban eltérnek egymástól. Ennek eredményeképpen megfelelő körülmények között intenzív mennyiségekben térbeli gradiens kialakulására van lehetôség. Hidrodinamikai instabilitások által keltett folyadékáramlást számos esetben figyeltek meg reakció-diffúzió-advekció rendszerekben. Ezek jellemzője egy autokatalitikus lépés a reakciómechanizmusban, illetve hogy a reakció lejátszódását térben és időben az autokatalitikus komponensek diffúziója szabályozza. Autokatalitikus reakciókban a reakció előrehaladtával annak sebessége folyamatosan növekszik, hiszen a termékben megjelenő komponensek között található olyan, amely reaktánsa is a reakciónak. Az autokatalitikus folyamatok több sajátos jellemzôvel is bírnak. Egyrészt érdekes tulajdonságuk, hogy a reakció addig nem indul el, amíg minimális mennyiségú terméket nem adunk a rendszerhez. Katalizátor hozzáadását követően a reakció beindul, és egy kezdeti lassabb szakasz után a reakciósebesség folyamatosan nô az egyre növekvő katalizá- 
tormennyiség hatására. A folyamat tehát a pozitív visszacsatolás hatására öngerjesztő. Ez a sajátosság jólkevert rendszerben arra vezet, hogy a reaktánsok a rövid indukciós periódust követôen hirtelen termékké alakulnak. Kevertetésmentes körülmények között a termékként képződő katalitikus komponensek térbeli eloszlását azok diffúziója fogja szabályozni, így akármilyen gyors is a reakció a termékek térbeli eloszlását a különböző transzportfolyamatok fogják meghatározni. Ez olyan érdekes jelenségek kialakulásához vezet, mint például a kémiai frontok, hullámok és különböző térben és időben is változatos mintázatok. Az ilyen rendszereket nevezzük reakció-diffúzió rendszereknek. A legegyszerúbb, egy autokatalitikus lépést tartalmazó reakció-diffúzió rendszerek a frontreakciók. Az ilyen folyamatokban az anyag átalakulása egy éles határvonal mentén játszódik le - ezt a vonalat nevezzük reakciófrontnak - mely a reakció és a katalizátorként viselkedő komponensek diffúziójának és a reakció kölcsönhatásából alakul ki. A határvonal állandó sebességgel és alakkal halad mindaddig, amíg rendelkezésre állnak reaktánsok. A frontok terjedési sebességét a katalitikus komponensek közegbeli diffúziója, illetve a reaktánsok kezdeti koncentrációja határozza meg a (2.3) egyenlet alapján:

$$
v \propto \sqrt{k D}
$$

ahol $k$ látszólagos elsőrendú sebességi együttható, $D$ pedig az autokatalizátor diffúziós együtthatója [40].

A reakciófront tehát egy reaktív határfelület, amely a reaktánsokat alakítja termékké és ezáltal két fizikai tulajdonságaiban eltérő oldatrészt választ el térben egymástól. A két oldatrész között a reakció során végbemenő összetétel-változás hatására súrúségkülönbség, viszkozitáskülönbség, felületi feszülttség-különbség és jelentôs entalpiaváltozás esetén hômérséklet-különbség is kialakulhat. Ezen intenzív változókban kialakuló gradiensek a már korábban bemutatott módon hidrodinamikai instabilitások kialakulásához vezethetnek, melyek áramlást keltenek a folyadékban. Az indukált közegmozgások a reakció-diffúzió front alakját és terjedésének sebességét is megváltoztatják. A front alakjában és sebességében bekövetkező változások vizsgálatával pedig következtetni tudunk az indukált áramlások tulajdonságaira.

Az 1980-as években fektették le az elméleti alapjait a reakció-diffúzió-advekció rendszerekben megfigyelhető konvektív áramlásoknak. Ebben az időszakban ugyanis ugrásszerúen megnőtt azon kémiai rendszerek száma, melyekben frontreakciót figyeltek meg. Ezek vizsgálata során vették észre, hogy a frontok terjedési sebessége függ a terjedés irányától. Bazsa és Esptein a vas-salétromsav rendszerben [41], később Nagypál és társai a klorittioszulfát rendszerben mutatták ki ugyanezt a jelenséget [42]. A 90-es évek elején Pojman és munkatársai írták le általánosan a megfigyelt jelenségek mechanizmusát [43]. Az eltérô frontsebességek a reakció során bekövetkezô sưrűségváltozásból adódtak. A sưrúségválto- 
zás származhat a folyamat során felszabaduló reakcióhőből, illetve az összetétel-változásból. Amennyiben a reakció során a sưrúség nő, úgy a Rayleigh-Taylor-instabilitásnak megfelelően a fentrôl lefelé haladó front instabil rétegződést hoz létre. Csökkenő sûrúség esetén az ellenkező irányba terjedô front lesz instabil. Az instabilitás hatására folyadékáramlás indukálódik, mely a front sebességét megnöveli, a front alakját pedig eltorzítja.

Endoterm autokatalitikus reakciót napjainkig nem találtak. Exoterm reakciók esetén pedig az összetételváltozás és a reakció által termelt hő együttesen változtatja meg a termék oldatrész sûrúségét, és amennyiben a változás előjele megegyezik, egyszerú konvekció lép fel. Azonban több rendszerben is megfigyeltek ellentétes előjelú változást, mely bonyolult folyadékáramlást eredményez. Ilyen rendszer a már korábban említett vas(II)-salétromsav rendszer, illetve a klorit-tetrationát rendszer [44-47].

A tudományterület talán legalaposabban vizsgált reakciójában a Belouszov-Zsabotyinszkij (BZ) reakcióban is leírták a konvektív áramlások jelenlétét [48]. Kevertetés nélküli rendszerben a BZ-reakció során periodikus kémiai hullámok haladnak a térben. A periodikusan megváltozó összetétel oszcilláló áramlást kelt a folyadékban. Azonban a sưrúségváltozásból eredő áramlások mellett egy újabb, az összetétel-változás hatására bekövetkező felületi feszültség változás miatt kialakuló áramlást is azonosítottak [49]. Ugyanebben a rendszerben modellszámításokkal is igazolták a Marangoni-instabilitás jelenlétét [50]. Korábban már Showalter is kimutatta, hogy ferroin-bromát rendszerben a szabad folyadékfelszínnek jelentôs hatása van a kialakuló mintázatra [51]. Míg reakció-diffúzió rendszerekben a Marangoniinstabilitásnak csak a front alakjára van jelentős hatása, addig egymással elegyedô rendszerekben a keltett áramlások az anyag- és hőátadási folyamatok intenzitását növelhetik [52].

A Marangoni-instabilitás hatását oldalirányban terjedő frontok stabilitására Anne De Wit és Laurence Rongy vizsgálta számos elméleti munkában. Számításokkal leírták, hogy hogyan változna a reakciófront alakja olyan esetben ha a felületi feszültség növekedne a reakció során és fordítva, ha a termék oldatrész felületi feszültsége lenne alacsonyabb [53]. További számításokat végeztek annak vizsgálatára, hogy a folyadékréteg változtatásával hogyan változik a Marangoni-instabilitás reakciófront tulajdonságait befolyásoló hatása [54].

\subsection{Jodátion-arzénessav reakció}

Az arzénessav jodátionokkal történô autokatalitikus oxidációja (IAA reakció) számos egzotikus viselkedést mutat. Maga a reakciómechanizmus igen összetett, de már korán megmutatták, hogy két részlépés alkalmazásával jól leírható a folyamat [55]. Az egyik lépésben a jodátion a jodidiont oxidálja savas körülmények között. A reakció eredményeként molekuláris jód keletkezik: 


$$
\mathrm{IO}_{3}^{-}+5 \mathrm{I}^{-}+6 \mathrm{H}^{+} \longrightarrow 3 \mathrm{I}_{2}+3 \mathrm{H}_{2} \mathrm{O}
$$

Ezt a folyamatot annak leírójáról nevezték el Dushman-reakciónak [56]. A reakció empirikus sebességi egyenlete

$$
r_{1}=\left(k_{1}+k_{2}\left[\mathrm{I}^{-}\right]\right)\left[\mathrm{I}^{-}\right]\left[\mathrm{IO}_{3}^{-}\right]\left[\mathrm{H}^{+}\right]^{2},
$$

ahol $k_{1}=4,5 \cdot 10^{3} \mathrm{dm}^{9} /\left(\mathrm{mol}^{3} \mathrm{~s}\right)$ és $k_{2}=1,0 \cdot 10^{8} \mathrm{dm}^{12} /\left(\mathrm{mol}^{4} \mathrm{~s}\right)$. A (2.4) reakcióban keletkezett jód a következó lépésben arzénsavvá oxidálja az arzénessavat. Ez a reakció a Roebuckreakció [57]:

$$
\mathrm{H}_{3} \mathrm{AsO}_{3}+\mathrm{I}_{2}+\mathrm{H}_{2} \mathrm{O} \rightleftharpoons 2 \mathrm{I}^{-}+\mathrm{H}_{2} \mathrm{AsO}_{4}^{-}+3 \mathrm{H}^{+}
$$

mely az $r_{2}=k_{3}\left[\mathrm{I}_{2}\right]\left[\mathrm{H}_{3} \mathrm{AsO}_{3}\right] /\left(\left[\mathrm{I}^{-}\right]\left[\mathrm{H}^{+}\right]\right)$empirikus sebességi egyenlet szerint játszódik le, ahol $k_{3}=3,2 \cdot 10^{-2} \mathrm{~mol} /\left(\mathrm{dm}^{3} \mathrm{~s}\right)$ [58]. A (2.6) lépés jóval gyorsabb az első lépésnél, így a Dushman-reakció a sebességmeghatározó folyamat.

A reakció során keletkező termék összetétele a reaktánsok kiindulási koncentrációjának arányától $\left(R=\left[\mathrm{H}_{3} \mathrm{AsO}_{3}\right]_{0} /\left[\mathrm{IO}_{3}\right]_{0}\right)$ függ. Amennyiben az arzénessav van feleslegben, vagyis $R>3$ esetén a reaktánselegy teljes jodátion-tartalma jodidionná redukálódik:

$$
\mathrm{IO}_{3}^{-}+3 \mathrm{H}_{3} \mathrm{AsO}_{3} \longrightarrow \mathrm{I}^{-}+3 \mathrm{H}_{2} \mathrm{AsO}_{4}^{-}+3 \mathrm{H}^{+}
$$

Ha azonban a reaktánsoldatban a jodátionok vannak sztöchiometriai feleslegben $(R<2,5)$, az arzénessav teljes mennyisége arzénsavvá oxidálódik miközben a jodátionok jóddá redukálódnak.

$$
2 \mathrm{IO}_{3}^{-}+5 \mathrm{H}_{3} \mathrm{AsO}_{3} \longrightarrow \mathrm{I}_{2}+5 \mathrm{H}_{2} \mathrm{AsO}_{4}^{-}+\mathrm{H}_{2} \mathrm{O}+3 \mathrm{H}^{+}
$$

Ezen két összetétel között a bruttó reakció a (2.7) és a (2.8) egyenletek lineáris kombinációjaként áll elô. Például $R=8 / 3$ esetén a (2.9) egyenlet írja le a folyamatot. Ebben az esetben a termék trijodidiont tartalmaz, mely a $\mathrm{I}_{2}+\mathrm{I}^{-} \rightleftharpoons \mathrm{I}_{3}^{-}$egyensúlynak megfelelően disszociál jódra és jodidionra.

$$
3 \mathrm{IO}_{3}^{-}+8 \mathrm{H}_{3} \mathrm{AsO}_{3} \longrightarrow \mathrm{I}_{3}^{-}+8 \mathrm{H}_{2} \mathrm{AsO}_{4}^{-}+\mathrm{H}_{2} \mathrm{O}+6 \mathrm{H}^{+}
$$

Az IAA rendszerben a jodid - amely a Roebuck reakcióban termelődik - autokatalizá- 
torként viselkedik a folyamat során, mivel a Dushman-reakcióban a jodid reaktánsként vesz részt. Az arzénsav erősebb sav az arzénessavnál, ezért a Roebuck reakció termékeként megjelenô proton szintén autokatalizátora a folyamatnak. Ez miatt, mint minden savkatalizált frontreakcióban a folyamat elektrokémiai úton, fémpárra kapcsolt elektromos feszültséggel iniciálható. A reakció az IAA-rendszerben szabad szemmel is jól követhető, mert a termékelegyben megjelenő jód, illetve trijodidion élénk sárga színúre festik a kezdetben színtelen oldatot. A kezdeti koncentrációarányoktól függően a sárga szín megjelenése lehet átmeneti vagy állandó. Arzénessav feleslegben ugyanis a jód csak közti termékként jelenik meg a reakcióban, míg jodátion feleslegnél a jódot fogyasztó arzénessav elfogy és így a jód felhalmozódik. Amennyiben a reakciót kevertetés nélkül játszatjuk le egy újabb érdekes jelenséget figyelhetünk meg. Ez esetben az iniciálást követően megjelenő termékoldatrész az iniciálás helyétôl minden irányban egyenletes sebességgel terjed. A jól kevert rendszerhez hasonlóan ilyen körülmények között is eltérő viselkedést figyelhetünk meg a kezdeti reaktánskoncentrációk arányától függően. Arzénessav-felesleg esetén vékony sárga vonalként terjed a front, amely elôtt és mögött is színtelen az oldat, míg jodátfeleslegben a reakciófront helyét a termék oldatrész sárga színe és a színtelen reaktánselegy közötti éles határvonal jelenti [59].

Az IAA-rendszerben a reakció lejátszódása során függőleges csőben haladó frontok esetén, a front haladási irányától függően eltérő frontalakot és terjedési sebességet figyeltek meg [60]. A függőlegesen lefelé haladó front sebessége nem függött a cső átmérôjétől, ellenben a felfelé haladó frontok esetén a csőátmérôvel növekvő frontsebesség értékeket tapasztaltak. Ugyanebben a munkában kimutatták, hogy a reakció lejátszódása során súrûségcsökkenés mérhetô, tehát a termék sûrúsége kisebb mint a reaktánsoldaté. Ez felfelé haladó front esetén hidrodinamikailag instabil rétegződést jelent, az alul elhelyezkedô kisebb sưrűségú oldatra felhajtó erô hat és emiatt növekszik a front terjedési sebessége. Ilyen elrendezésben kis átmérôjư csốben egyenes alakú frontot tapasztaltak, majd növelve a csô átmérôjét a front a csố tengelyére aszimmetrikus görbült alakot vett fel [61]. Egy bizonyos csőátmérő felett a görbület tengely-szimmetrikussá vált. Lefelé haladó frontoknál a rétegződés a csőátmérôtől függetlenül stabil marad. A megfigyelt frontalakokról készült felvételeket mutatja be a 2.2. ábra.

Kis csőátmérô esetén a front stabil marad, ugyanis az áramlás létrejöttéhez szükséges egy minimális átmérô ami teret biztosít egy konvekciós gyưrü kialakulásának. Ilyen helyzetben aszimmetrikus frontalak a jellemző. Tovább növelve a csốtmérôjét két ellentétes irányú konvekciós gyưrú mentén történik az áramlás középen a front haladási irányának megfelelő, míg a csô falának közelében pedig ellentétes irányban. Ebben az esetben a front alakja tengely-szimmetrikus.

Vízszintesen haladó front esetén már nem beszélhetünk stabil rétegződés kialakulásának lehetőségéről. Az ilyen elrendezésben haladó front a haladás irányába megdől, ahogyan az 


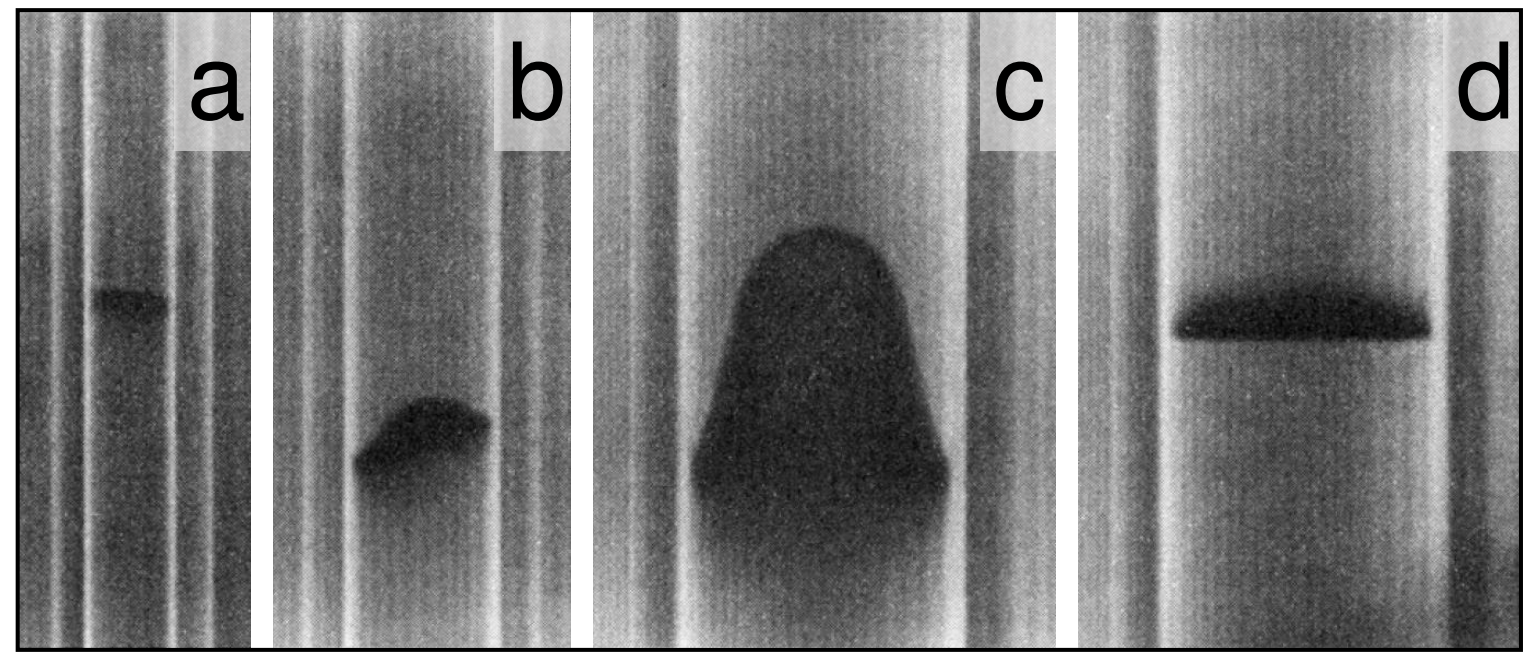

2.2. ábra. Különböző csőátmérőnél megfigyelhető frontalakok az IAA-rendszerben. Függőlegesen felfelé haladó frontok átmérôi $d=1,1 \mathrm{~mm}(\mathrm{a}), d=1,6 \mathrm{~mm}(\mathrm{~b}), d=3,2 \mathrm{~mm}$ (c) és a függőlegesen lefelé haladó front átmérője $d=3,2 \mathrm{~mm}$ (d) [61].

a 2.3 ábrán is látható. A front dőlése a kialakuló Rayleigh-Taylor-instabilitás miatt következik be, ugyanis az instabil rétegződésû eltérő sűrúségú oldatrészek áramlással igyekeznek stabil elrendeződést kialakítani.

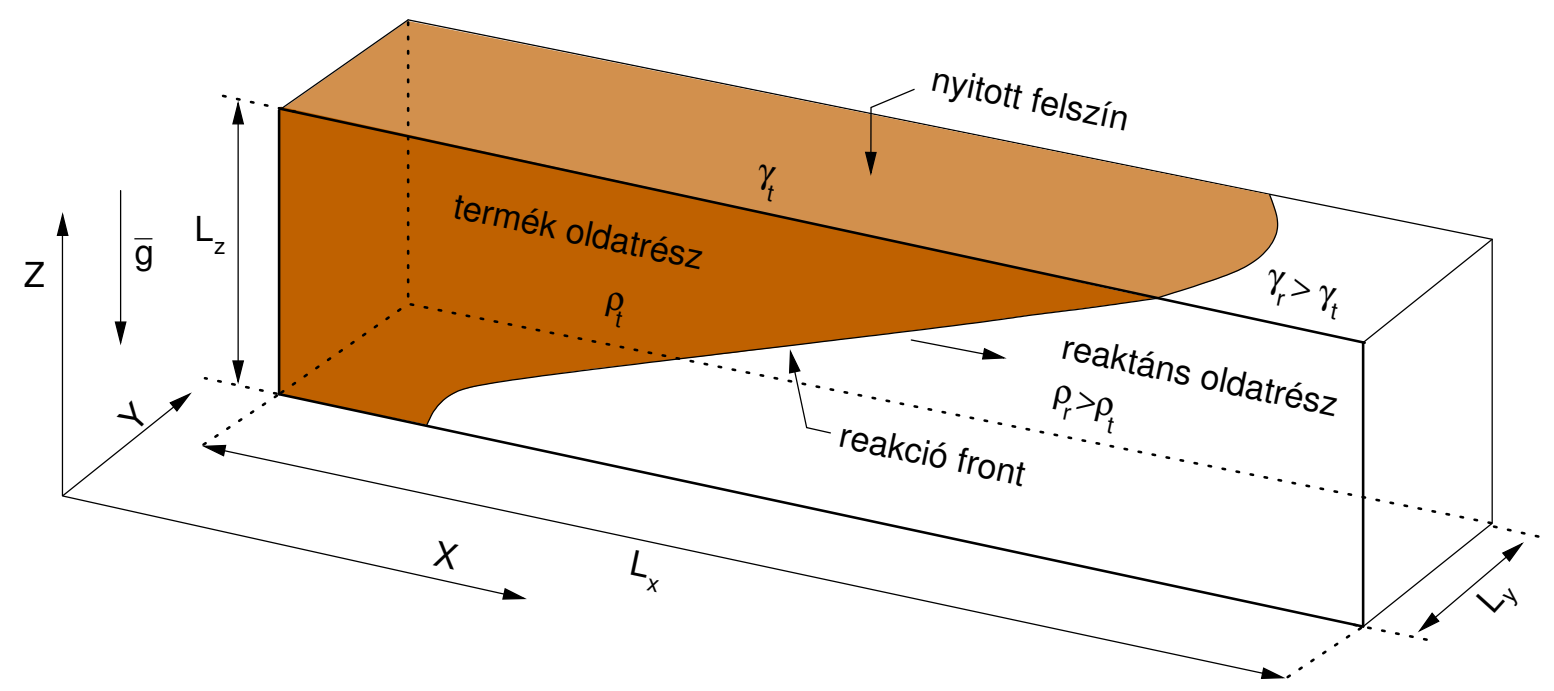

2.3. ábra. Horizontális elrendezésben terjedő reakciófront az IAA-rendszerben.

Az IAA-rendszerben a sürúségváltozás mellett a felületi feszültség is változik. A termékoldatrészben jelenlévő molekuláris jód ugyanis felületaktív anyag ami csökkenti a termék felületi feszültségét [62]. A felületi aktivitás a folyadék-gáz határfelületen történő dúsulásnak a következménye. A reakció során csökkenő felületi feszültség miatt a front haladási irányába mutató gradiens alakul ki. E gradiens jelenléte miatt olyan erő indukálódik a folyadék-gáz határfelületen, amely miatt front haladásával megegyező irányú folyadékáramlás indul meg. 
Ez természetesen csak olyan elrendezésben figyelhető meg, ahol a front oldalirányban halad és biztosított a nyitott felszín a reakcióedényben.

Az autokatalitikus jelleg miatt a reakciófront egyfajta önfenntartó módon halad a folyadékfázisban, így a felületi feszültségben és sûrüségben kialakult gradiensek nagysága állandó. Annak ellenére, hogy a front átjárható a különböző komponensek számára, a reakciódiffúzió-advekció rendszerekben nincs kiegyenlítődés sem a koncentráció- sem a sűrűségkülönbségben. A rendszer így folyamatosan egyensúlytól távoli állapotban van mindaddig, amíg a teljes reaktáns mennyiség konverziója meg nem történik. Emellett az IAA-rendszer azért is kiváló modellreakciója a méréseinknek, mert a reakció elhanyagolható exotermicitása miatt tisztán összetétel-különbség hatására kialakuló Marangoni-instabilitás vizsgálatát teszi lehetôvé. Továbbá a reakció során bekövetkezô színváltozás kiváló indikátora az eltérô fizikai tulajdonsággal rendelkező folyadékrészek térbeli elhelyezkedésének, mely a kísérleti munkát nagyban leegyszerúsíti.

\subsection{Mikrogravitáció}

A jodátion-arzénessav rendszerben tehát a felületi feszültség csökkenése mellett a sưrúség is csökken a reakció lejátszódása során. Földi körülmények között azonban a sûrúségkülönbségből származó áramlások a Marangoni-instabilitás hatását nagy mértékben torzítják. A Rayleigh-Taylor-instabilitás megszüntetéséhez a felhajtó erốt kiváltó tényezôt, a gravitációs erôteret kellene megszüntetni. Klasszikus értelemben vett mikrogravitációs környezet a Földtôl számított 3,5·10 $\mathrm{km}$-es távolságban lenne tapasztalható, ugyanis itt csökken le a Nap tömegéből származó gravitációs erôtér a $10^{-5} \mathrm{~m} / \mathrm{s}^{2}$ értékére. A Föld közelében tehát mikrogravitációs környezet nem állítható elô. Vannak azonban módszerek, amelyekkel a különböző méréseknek kitett eszközökre és anyagokra ható erôknek az eredôje úgy alakul, hogy az eszköz vagy anyag súlya több nagyságrenddel lecsökkenthetô. Ezen módszerek közös tulajdonsága, hogy mindegyik a szabadesés állapotába hozza a mérési eszközt. Albert Einstein által bevezetett ekvivalencia-elv kimondja, hogy nincs olyan kísérlet, amely lokálisan különbséget tudna tenni a tehetetlen és súlyos tömeg között egy gyorsuló vonatkoztatási rendszerben. Ennél fogva, ha egy test szabadon esik és semmilyen más erôk nem hatnak rá, akkor az elvégzett kísérletek eredményei függetlenek lesznek a gravitációs erôtér nagyságától. A testre ható erôk eredőjéből származó gyorsulás nagyságát szokás a $g$-vel jelölt értékkel kifejezni. Ez az érték $1 g$, ha a test gyorsulása éppen megegyezik a Földön tengerszinten mérhetố átlagos $9,81 \mathrm{~m} / \mathrm{s}^{2}$-os értékkel függetlenül attól, hogy ezt az eredô gyorsulást maga a gravitációs erôtér idézte elô vagy valamilyen más (tehetetlenségi) erô. Valódi súlytalanság állapotában ez az érték $\vec{a}=0 \mathrm{~g}$, mikrogravitációban pedig a $10^{-6} \mathrm{~g}$ nagyságrendú. Fontos tehát figyelembe venni, hogy amikor mikrogravitációs kísérletekrôl beszélünk, akkor 
a gyakran használt mikrogravitáció - esetenként a zéró-gravitáció - kifejezések a jól megválasztott gyorsulási értékek miatt kialakult eredő erő nagyságára vonatkoznak, nem pedig a gravitációs erôtér nagyságára. Bár ezen kifejezések megtévesztőek lehetnek első olvasatra, az ilyen kontextusban történő használatuk a tudományterületen általánosan elfogadott és a dolgozatom további részében is ennek figyelembe vételével használom.

Az egyik lehetôség ilyen körülmények előállítására, hogy egy úgynevezett ejtôtoronyban végzik el az adott kísérletet. A kísérletek során egy magas torony-szerú építményben néhány száz méteres magasságból ejtik le a kísérleti eszközt. A berendezést egy modulba építik be, amelyet a torony tetejébe emelnek. Ezt követôen a toronyból a levegôt kiszivattyúzzák, hogy csökkentsék a légellenállást a szabadesés során, majd megszüntetik a modul rögzítését. A szabadesés során a kísérlet online vezérelhetô, ha azt korábban nem automatizálták. A modul a szabadesést követôen polisztirol golyókkal teli fékezőtartályba esik, biztosítva így a kísérleti berendezések újrafelhasználhatóságát. Abban az esetben, ha a kísérleti modult a torony tetejéből ejtik le, akkor néhány (jellemzően 4-5) szekundum szabadesés áll rendelkezésre [63]. Elérhető azonban egy katapultszerú indítás, ahol a modult a torony aljáról indítják, katapult szerúen majd engedik visszaesni a torony aljába. Ezzel a módszerrel megkétszerezhetố a szabadesés idôtartama, de ebben az esetben sem haladja meg a 10 másodpercet [64]. Jelenleg az Európai Û́rügynökség által használt Bréma városában található ZARM ejtőtoronyban igen alacsony, $10^{-5}-10^{-6} g$ nagyságú mikrogravitáció állítható elő igaz csak maximum 9,3 másodperces időtartamban.

Ennél hosszabb idôtartamot biztosítanak a parabolarepülések. Az ilyen repülések során átalakított utasszállító repülőgépekkel végeznek precíziós repülést olyan módon, hogy a repülőgép szabadesését idézik elő. Ezt úgy érik el, hogy a repülőgépet ballisztikus pályára vezetik úgy, hogy eredő gyorsulása éppen kiküszöböli a gravitációból, illetve minden egyéb oldalirányú erôkből származó gyorsulásokat [65,66].

A parabolarepülések során az ejtőtoronyban elvégzett kísérletekhez képest a rendelkezésre álló mikrogravitáció időtartama egy parabola során legalább megkétszereződik. A mikrogravitáció minősége azonban jelentôsen rosszabb. A 2.4 ábrán látható parabola során a mikrogravitáció értéke $a_{z} \sim 10^{-3} \mathrm{~g}$, mely legalább két nagyságrenddel nagyobb, mint az ejtốtoronyban elérhetô érték. Azt azonban meg kell említeni, hogy míg az ejtôtoronyban napi 3 kísérlet végezhető el a vákuum előállításához és megszüntetéséhez szükséges idô miatt, addig a parabolarepülés során egy nap több tízszer ismételhető a mikrogravitációs szakaszok száma. Az Európai UUrügynökség évente jellemzően két parabolarepülést szervez és repülésenként 10-13 kísérlet van a repülőgép fedélzetén. A parabolarepülés egyik legnagyobb előnye, hogy a repülések során a kísérleti berendezéssel együtt a kísérletet végzô személyzet is jelen lehet. Ez biztosítja a lehetôséget arra, hogy a méréseket folyamatosan figyelemmel kísérje valaki, vagy ha nem automatizált a mérés, akkor azt a személyzet kontrollálja. A 


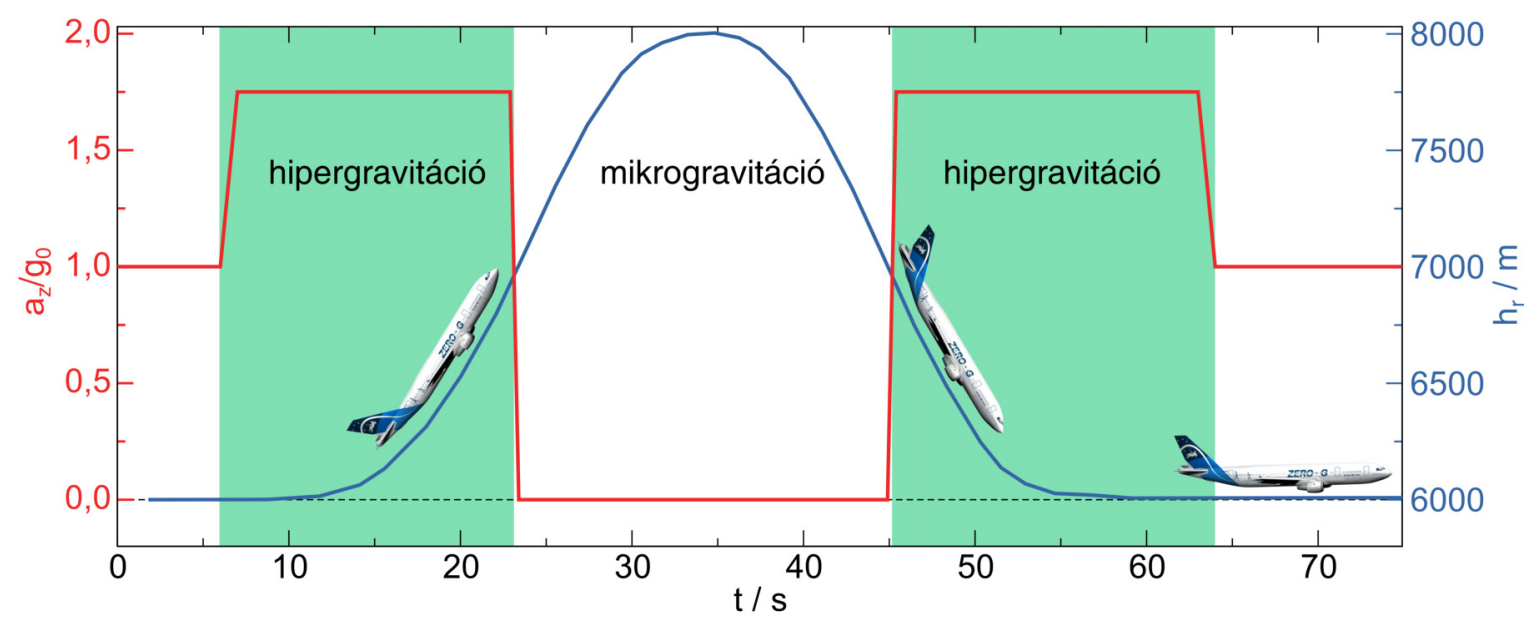

2.4. ábra. A repülés során mikrogravitáció előállítására használt parabolaprofil és a $z$ irányban mérhetô gyorsulás értéke egy profil során.

parabolarepülések során a fizikai, kémiai tárgyú kísérletek elvégzése mellett lehetőség van olyan biológiai kísérletek végrehajtására, melyek az emberi test válaszreakcióit vizsgálják a mikro- vagy hipergravitációs állapotokra.

A parabolarepülésnél egy nagyságrenddel hosszabb az egyhuzamban előállítható mikrogravitációs periódus a szuborbitális kísérleti rakéták fedélzetén. A rakétákat arra tervezik, hogy a kísérleti berendezéseket tartalmazó hasznos terhet minél nagyobb magasságba juttassák, hogy aztán a motor leválasztása után ballisztikus pályán szabadeséssel visszatérjen a Föld felszínére. Ezek a repülések jellemzően 2-20 percnyi mikrogravitációs időtartamot tudnak biztosítani attól függően, hogy milyen magasságot ér el a rakéta. A repülés profilja ebben az esetben is egy parabola görbének felel meg a kilövést követô kezdeti szakaszt és a végsố ereszkedést kivéve. A repülések tetôpontja általában több mint $100 \mathrm{~km}$, ugyanis ebben a magasságban már annyira ritka a légkör, hogy a légellenállás nem befolyásolja a rakéta haladását, így nem is hatnak rá ebből adódó egyéb erôk. A mikrogravitáció időtartamának vége szintén a körülbelül 100 km-es magasság újbóli elérése után található. A visszatéréskor a zuhanó és egyre gyorsuló hasznos teher az egyre sûrúbb légkörben súrlódva hirtelen erőhatásoknak kitéve lassul. A modulok vagy legalábbis azok egyes részeinek újrafelhasználhatóságának érdekében a repülés végső fázisa általában nem zuhanás, hanem ejtôernyős ereszkedés.

További nagyságrendekkel hosszabb mikrogravitációs időtartamot már csak a kísérleti berendezések Föld körüli pályára állításával lehet elérni. Erre több lehetőség is adódik napjainkban. A legfontosabb mindegyik közül a Nemzetközi Ứrállomás (ISS). Az ưrállomás elsô modulját 1998-ban bocsájtották Föld körüli pályára, az első expedíció pedig 2000. november 2-án érkezett meg az ûrállomásra és azóta folyamatos az emberi jelenlét. Ettől a dátumtól kezdve áll rendelkezésére az emberiségnek olyan laboratórium, amely állandó mikrogravi- 
tációban van. A nemzetközi ûrállomáson tehát gyakorlatilag időkorlát nélkül végezhetők el kísérletek jó minőségű mikrogravitációs állapotban. Az állandóan jelenlévő személyzet miatt ráadásul a kísérletek folyamatosan kontrollálhatók, többször reprodukálhatók. Természetesen az UUrállomáson is vannak a kísérleti berendezés súlyára és méretére vonatkozó korlátozások, de korántsem olyan szigorúak, mint egy ejtőtorony vagy rakétakísérlet esetén. Ezen kísérletek során a legfőbb korlátozó tényezô a legénység rendelkezésre állási ideje. Mivel az asztronauták elsődleges feladata a tudományos kísérletek elvégzése, a fenntöltött idejük nagy része a különböző kísérletek között oszlik meg. Föld körüli pályán történő mérések kivitelezhetôk külön erre a célra épített múholdakon is. Ilyen esetben a rendelkezésre álló mikrogravitációs időtartam néhány naptól néhány hónapig terjed. Jó példa erre az orosz fejlesztésű BION és FOTON nevet viselő múholdak. Az első BION mûholdat 1973-ban bocsátották fel és 22 napig keringett a Föld körül. 1996-ig további 10 követte és kivétel nélkül biológiai kísérletekkel a fedélzetükön repültek. Ezen kísérletek tárgya a mikrogravitáció és a kozmikus sugárzás növény- és állatvilág különböző szereplőire gyakorolt hatásának vizsgálata volt. A FOTON és FOTON-M rakéták teljesen hasonló konfigurációjú múholdak voltak csak főként anyagtudományi témájú kísérleteket szállítottak [67].

A mikrogravitációban végzett fluid-dinamikai kíséreltek során túlnyomórészben azt a kedvező hatást használják ki, hogy ilyen körülmények között megszűnnek a gravitációs gyorsulás miatt ébredő tömegerôk ezáltal a folyadékokban nem lép fel hidrosztatikai nyomásgradiens. Ennek a ténynek a legsúlyosabb következménye, hogy felhajtóerő sem generálódik fluidumokban, így az anyag- és hőátadási folyamatok hatásfoka nagymértékben lecsökken. Ennek a mérnöki tervezésben igen nagy jelentősége van, minden ûrtechnikai eszközt ennek figyelembevételével kell megtervezni. Pozitív hozadéka is van a gravitációs gyorsuláshoz kapcsolódó tömegerôk megszúnésének. Ezáltal ugyanis olyan egyéb erôk hatásai erôsödnek fel, melyek relatív hatását Földi körülmények között nem lehet megfigyelni. Ezt igen korán felismerték és már az Apollo-program repülései során végeztek folyadékáramlással kapcsolatos, illetve anyagtudományi kísérleteket. A program 17 repüléséből 10 jutott el a Holdig. A Föld-Hold távolságot 3 nap alatt tette meg a jármú, mely időtartamban a legénység kísérleteket is végezhetett. Olyan kísérletből, melyek nem az ưrbéli körülmények leírására irányultak, hanem a mikrogravitáció hatására, nyolcat végeztek három repülés során (Apollo-14 , Apollo-16 és Apollo-17) [68]. Az Apollo-14 fedélzetén egy kompozit előállításával elemezték különböző sûrûségú részecskék eloszlását a fémolvadékban, vizsgálták az elektroforézis hatásfokának növekedését mikrogravitációban, tanulmányozták különböző tartályok közötti folyadékátvitelt és a tartályok feltöltôdésének folyamatát, illetve végeztek kísérleteket konvektív folyadék- és gázáramlás tanulmányozására [69]. Ez utóbbit Stuart Roosa, a parancsnoki modul pilótája hajtotta végre 1972. február 7-én a jármú Holdtól történő hazarepülés során. A kísérlet gyakorlatilag Henri Bénard mérésének mikrogravitációs 
körülmények közötti megismétlése volt kiegészítve a gázfázisban történő konvektív áramlás vizsgálatával [70]. Az Apollo-16 repülése során egy biológiai kísérlet keretei között vizsgálták a megnövekedett kozmikus sugárzás különböző organizmusokra gyakorolt hatását. A biológiai mérés mellett az elektroforetikus analízist egészítették ki: oldatok helyett makrorészecskék mozgását elemezték. Az utolsó, 17. Apollo küldetés fedélzetén a biológiai méréseket folytatták és a Bénard-féle kísérlet módosított változatában végeztek vizsgálatokat [71]. Azóta is a mikrogravitációban végzett anyagtudományi mérések jelentős hányada kapcsolódik a folyadékfázisbeli megváltozott áramlási körülményekhez.

A Marangoni-instabilitás által keltett áramlások vizsgálata igen intenzíven folyt az elmúlt negyven évben. Ezen vizsgálatok középpontjában döntő részben a hőmérséklet gradiens hatására kialakuló Marangoni-instabilitás volt. 2009-ig bezárólag legalább tizenhét szuborbitális rakétakísérlet, hét ûrsikló fedélzetén és két, a Nemzetközi Ứrállomás fedélzetén elvégzett kísérlet foglalkozott kristálynövesztés során fellépő Marangoni-instabilitásból származó áramlások vizsgálatával [72]. Az intenzív kutatást a nagy tisztaságú félvezetők iránti hatalmas igény indokolja. 


\section{Célkitúzés}

Kutatócsoportunkban korábban már kimutatták, hogy a IAA-rendszerben kialakuló Marangoni-instabilitás által keltett folyadékáramlás, a Rayleigh-Taylor-instabilitás hatása mellett kimutathatóan torzítja a reakciófront alakját [62]. Célom, hogy az Európai Úrügynökség által a csoportunknak biztosított támogatással élve, különleges mérési körülmények között vizsgáljam az instabilitások hatását a reakciófrontra. Elsőként modulált gravitációs erôtérben végeztem méréseket annak érdekében, hogy megtaláljam az optimális kísérleti paramétereket. Mikrogravitációban a folyadékok áramlása eltér a gravitációs erőtérben tapasztaltaktól: a hidrosztatikai nyomásgradiens hiánya miatt csak a felületi erők tartják egyben a folyadékfázist. A határfelületi erők nagyságrendekkel kisebbek, mint a nehézségi erők így mikrogravitációban fontos megtalálni azt az áramlási sebességet, melynél a mérôcella feltölthető olyan módon, hogy a folyadék-gáz határfelület egy egységet alkosson. A másik fontos optimalizálandó kísérleti paraméter az elektromos feszültség segítségével elvégzett iniciálás hossza volt. Földi körülmények között a keletkező termékoldatrész a felhajtóerő okozta áramlás hatására elkeveredik a reaktánsoldattal így a reakció indítása nem ütközik nehézségekbe. Mikrogravitációban végzett iniciálásról nem volt még korábbi tapasztalatunk, így ennek elvégezhetôségét is megvizsgáltam. A parabolarepülések során készült videófelvételek segítségével olyan mérések is elvégezhetôk voltak, melyek eredményeként kvalitatív következtetéseket le tudtam vonni a két instabilitás által keltett folyadékáramlásról és annak a reakciófront alakjára gyakorolt hatásairól.

A szuborbitális rakétakísérletekkel a tisztán Marangoni-instabilitás vizsgálata volt a célom. A repülés időtartama, illetve a mikrogravitáció minősége lehetôséget nyújt a RayleighTaylor-instabilitás megszüntetésére, így a parabolarepülés során szerzett tapasztalatokkal már várható volt, hogy a Marangoni-instabilitás hatását zavartalanul tudjuk tanulmányozni. A kísérletek során részecskeképen alapuló sebességmeghatározás módszerével már kvantitatív információt is nyertem a kialakult áramlás nagyságáról és irányáról.

A rakétakísérletekre jellemző helyhiány és rövid időtartam miatt az elvégezhetô kísérletek száma korlátozott, ismétlésre nincs lehetőség ésszerú keretek között. Emiatt célul tûztem ki, hogy a kísérletek során nyert eredmények segítségével felállítsak egy numerikus modellt. A reakció-diffúzió-advekció modellen alapuló numerikus szimulációkkal univerzálisan vizsgálható, hogy a Marangoni-instabilitás különböző paraméterek mellett milyen folyadékáramlást indukál és az milyen hatással van a kialakult frontalakra. 


\section{Kísérleti módszerek és eszközök}

\subsection{Parabolarepülés}

A tisztán mikrogravitációban végzett kísérletek előtt számos kísérleti paraméter meghatározása mellett a jelenség ilyen körülmények közötti vizsgálhatóságát is kívántuk tisztázni. Erre a parabolarepülés is alkalmas körülményeket biztosít a gravitációs erőtér minőségének és időtartamának tekintetében. A kísérletek során nyert adatokból azonban sikerült tudományos következtetéseket is levonni. A repülés során a mikrogravitációs állapotot a repülőgép úgynevezett parabola pályán történő vezetésével érik el. A pálya alakja, illetve az így előállított gyorsulási erôk nagysága a 4.1. ábrán látható. Az ábrázolt parabola során $\mathbf{g}_{z}$ pontos értéke $-1,758 \cdot 10^{-3} \pm 4,904 \cdot 10^{-3} g$ volt.

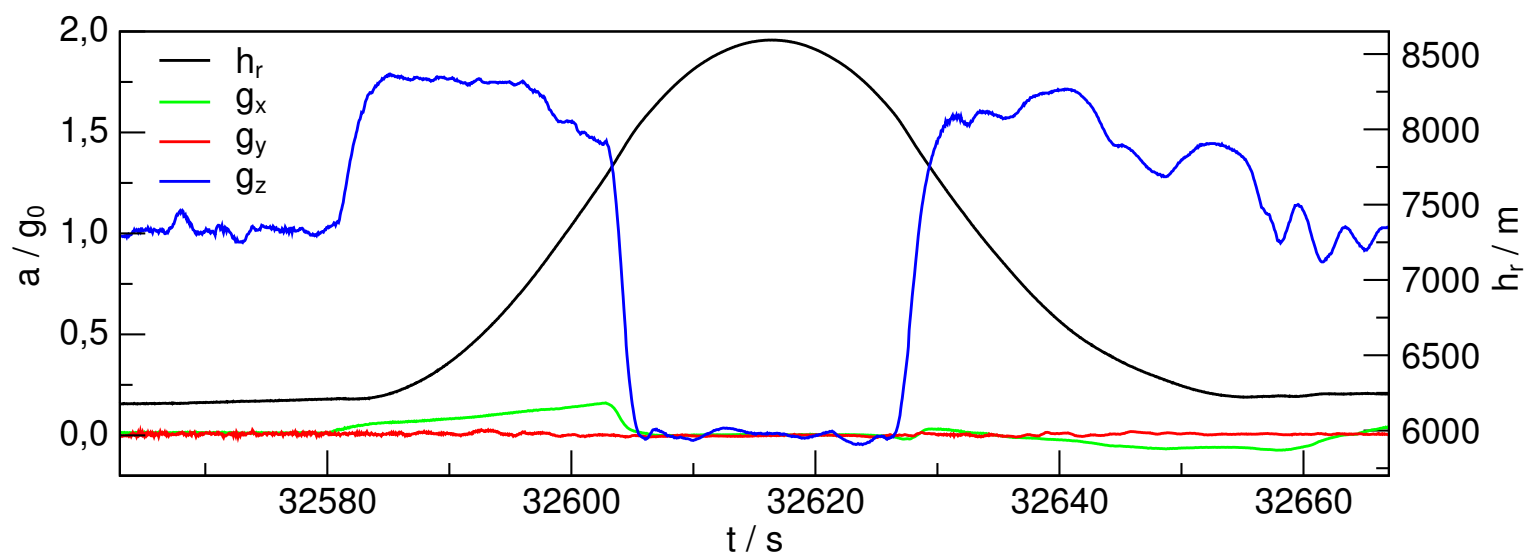

4.1. ábra. A gyorsulási erők és a repülőgép magasságának alakulása egy parabola manőver során.

Egy repülés során egy adott szekvenciának megfelelôen repülésenként harmincegy ilyen manővert hajtanak végre. Egy parabola időtartama körülbelül egy perc és két parabola manôver között kettő perc idôtartamot biztosítanak a kísérletet végző személyzetnek a szükséges módosítások elvégzésére. Öt manőver után hosszabb szünetek is rendelkezésre állnak. Az ötödik és a tizedik után öt-öt perc, a tizenötödik után nyolc, a huszadik és huszonötödik manőver után szintén öt-öt perc szünetet tartanak. A repülés időtartama így körülbelül 120 perc, melyből tisztán 10-10,5 perc a mikrogravitációs időszak. Az általunk végzett kísérletek elvégzéséhez 3 személynek kellett a repülőgép fedélzetén tartózkodnia és egy megadott protokoll alapján csapatként együtt dolgoznia.

A kísérletek során az Európai Ưrügynökség, illetve a repülést kivitelező francia Novespace vállalat iránymutatásai alapján teljes egészében a kutatócsoport által tervezett és elkészített kísérleti berendezést használtunk. 


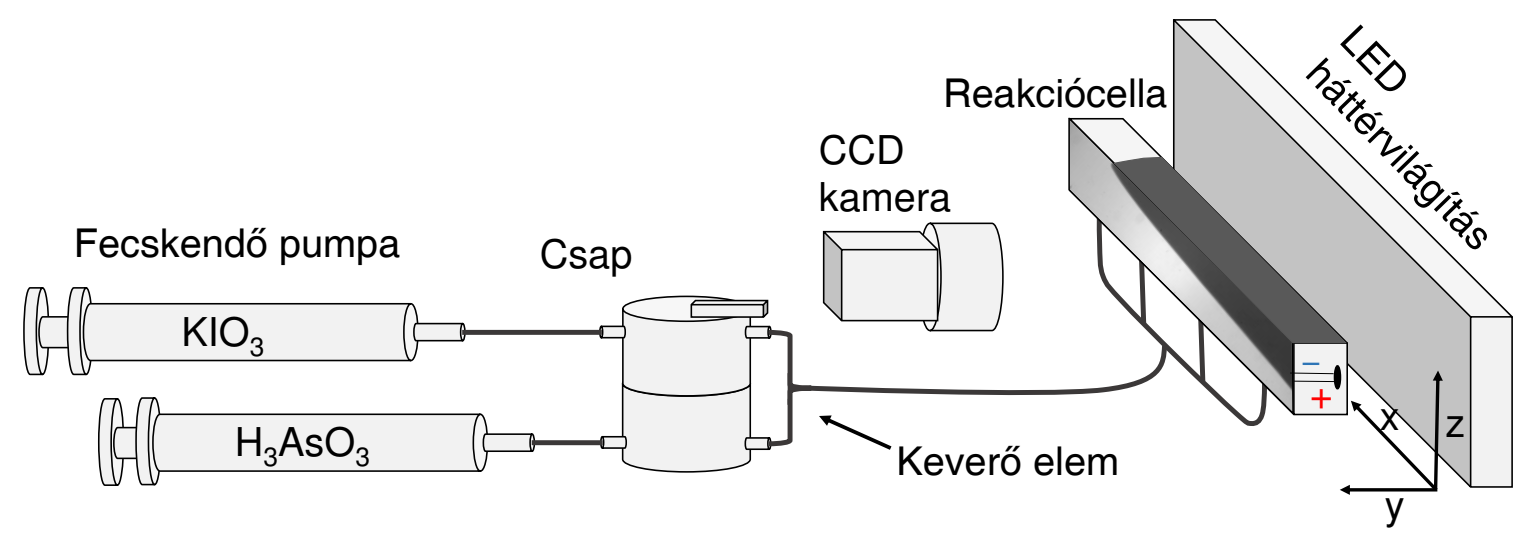

4.2. ábra. A parabolarepülés során alkalmazott kísérleti elrendezés sematikus ábrázolása.

Tekintettel arra, hogy a reakció mellett a cellatöltést, illetve a reakció iniciálását is vizsgáltuk, egy repülés során több cellában is végeztünk kísérleteket. A reaktánsoldatokat kezdetben egymástól szeparáltan két fecskendőben helyeztük el. A töltést egy számítógépen keresztül kontrollálható fecskendő pumpával végeztük. Az oldatokat egy 6 kimeneti ággal rendelkező csapon keresztül juttattuk a kiválasztott cellába. Az oldatok keverése a csap után elhelyezett egyszerú T-csatlakozóban történt meg. A cellák a repülés során két helyzetben voltak rögzítve: nem használt cellák egy oldalsó tartóban, míg az éppen használatban lévő cella a LED fényforrás és a kamera közé helyezett tartóban. Az elrendezést és a berendezés főbb részeit a 4.2. ábra mutatja. Két kísérlet között a cellák cseréjét az egyik operátor végezte. A méréseket a 4.3. ábrán látható két, geometriájában alapvetôen eltérô cellában végeztük. A folyadék-gáz felszín kialakításához az egyik általunk „nyitott"-nak nevezett cellában egy vékony perem került kialakításra, mely biztosította, hogy teljesen sík folyadék-gáz határfelületet tudjunk létrehozni. A másik cellatípust „zárt" cellának neveztük, ezt a cellát teljes térfogatáig feltöltöttük a reaktánseleggyel. Az oldatot a nyitott cellákba alulról 4 bevezetésen keresztül, míg a zárt cellákba oldalról egy bevezetésen keresztül juttattuk be. A cellákon kivezetô nyílások is kialakításra kerültek a nyitott cellák esetén a levegő, zárt cellák esetén pedig a felesleges reaktánselegy szabad távozásának biztosítására.

A reaktánsoldatok koncentrációjának rendre $25,8 \mathrm{mmol} / \mathrm{dm}^{3}$, és $72,2 \mathrm{mmol} / \mathrm{dm}^{3}$-nek választottuk a jodát, illetve arzénessav oldatok esetén az $R=2,8$ aránynak megfelelóen. A reakció iniciálását teszteltük az y-tengellyel és a z-tengellyel párhuzamosan beépített vékony platina szálakra kapcsolt elektromos feszültség nagyságának és időtartamának változtatásával. 

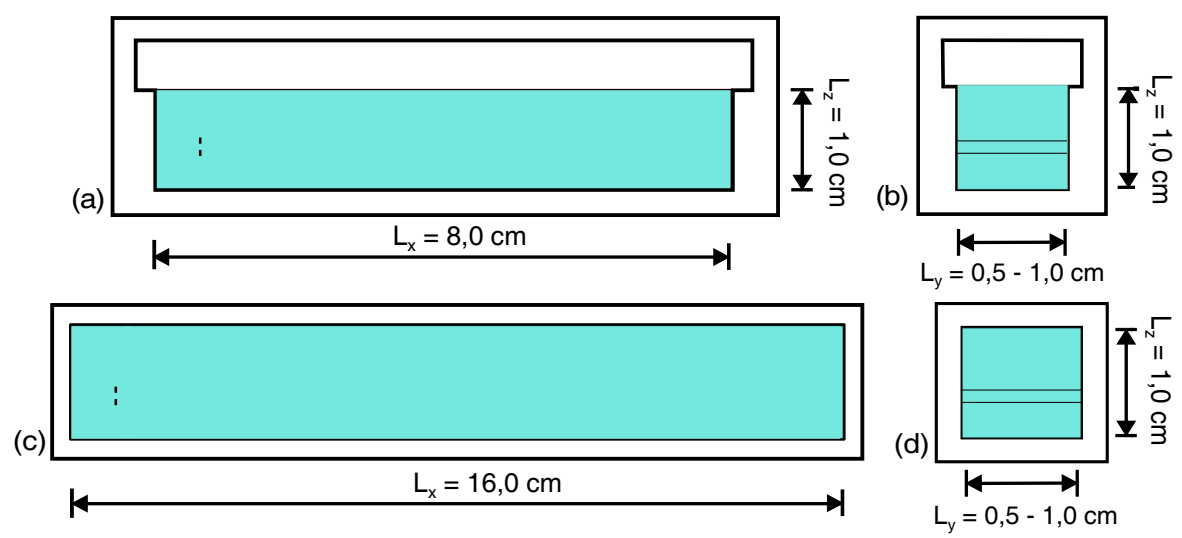

4.3. ábra. A parabolarepülés során használt cellák méretei és geometriája. Szabad folyadékgáz határfelület kialakítására alkalmas „nyitott” cella keresztmetszete az xz-síkban (a), az yz-síkban (b), illetve a ,zárt” cella keresztmetszete az xz-síkban (c) és az yz-síkban (d).

\subsection{Szuborbitális rakéta}

A hosszabb idôtartamot és tisztán mikrogravitációs fázist biztosító rakétakísérleteknél már jóval komolyabb előírásoknak kellett megfelelni. A parabolarepüléssel ellentétben a kísérleti berendezést a kísérletet végzô tudományos csoport, a rakéta üzemeltetését végzô svéd SSC vállalat, illetve az Európai Úrügynökség iránymutatásainak megfelelően külső vállalatok tervezték és építették. A rakétamodul különálló főbb egységeit, úgymint az optikai elemeket és kamerákat tartalmazó képfeldolgozó rendszert, illetve az adatrögzítést és vezérlést magába foglaló részeket külön-külön mérnökcsapatok tervezték és hangolták össze. A modul múködésének tesztelésébe és az ez alapján elvégzendő módosításokba már a tudományos csoport is bevonásra került. A rakétamodul megépítésekor a legfőbb limitáló tényezőt a méret- és súlykorlátozás jelentette. A modul egy 17 hüvelyk átmérőjú kör alapterületú hengeres test, melynek magassága $96 \mathrm{~cm}$, végsô tömege pedig $73 \mathrm{~kg}$. Ebbe a hengeres testben kellett elhelyezni minden alkatrészt, amely a kísérlet sikeres elvégzéséhez szükséges volt. A különböző alkotók rögzítéséhez 3 különbözô magasságban kialakított tartó lapon volt lehetôség. A reakciócellák, a különböző optikai elemek, illetve a kamerák az alsó lapon kerültek elhelyezésre. A hidraulikus kör legfőbb elemeit a különbözô csapokat, szelepeket, illetve egy a hidraulikus kör mosásakor és a töltési procedúra során elvégzett öblítéskor használt folyadékot befogadó tartályt a középsô lapon helyezték el. A felsô lapra az adatrögzítô egységet, illetve a kísérlet energiaellátását biztosító akkumulátorokat építették. A modult úgy tervezték, hogy a külső borítás felhelyezését követően teljesen nyomástartó legyen, így a kísérlet teljes idôtartama alatt a tengerszintnek megfelelő nyomás biztosított volt. Túlságosan nagy hőmérséklet különbségek kialakulásának megakadályozását egy beépített ventilátor biztosította, révén, hogy a természetes konvektív hőáram a mikrogravitációs időszakban gátolt. A 
külső borításon kialakításra került egy „ajtó”, amelyen keresztül biztosított volt a modul reaktáns oldatokkal való feltöltése, illetve a hozzáférés a szükséges részekhez a tesztelés és az utána következő tisztítás során.
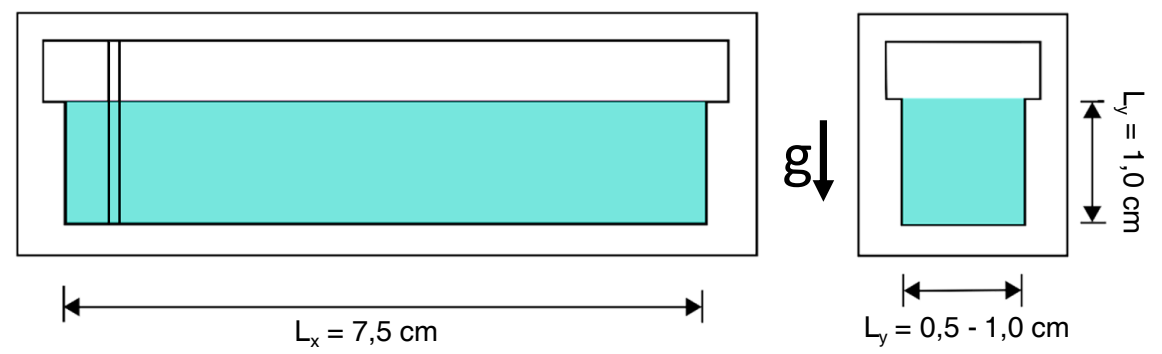

4.4. ábra. A rakétakísérlet során használt két eltérô méretû, szabad folyadék-gáz határfelület létrehozására alkalmas kísérleti cellák méretei és geometriája. A cellák keresztmetszete az $x z$-síkban (bal oldalon) és keresztmetszetük az yz-síkban (jobb oldalon).

A modulba két azonos geometriájú de eltérő méretű cella került beépítésre, melyek méretei a 4.4. ábrán láthatók. A rakétakísérletek során már csak szabad folyadék-gáz határfelület kialakítására alkalmas cellákban végeztünk kísérleteket a 4.5. ábrán látható elrendezésben. Az oldatokat e kísérlet esetén is két fecskendőben egymástól szeparáltan tároltuk és egy épített fecskendôpumpával juttattuk a reakció cellákba. A két eltérő méretû cellához két-két külön fecskendő tartozott. A modulból eltávolítva manuálisan töltöttük fel két fecskendôt 72,2 mmol/ $\mathrm{dm}^{3}$ koncentrációjú $\mathrm{H}_{3} \mathrm{AsO}_{3}$ oldattal, a másik két fecskendôt pedig $25,8 \mathrm{mmol} / \mathrm{dm}^{3}$ koncentrációjú $\mathrm{KIO}_{3}$ oldattal.

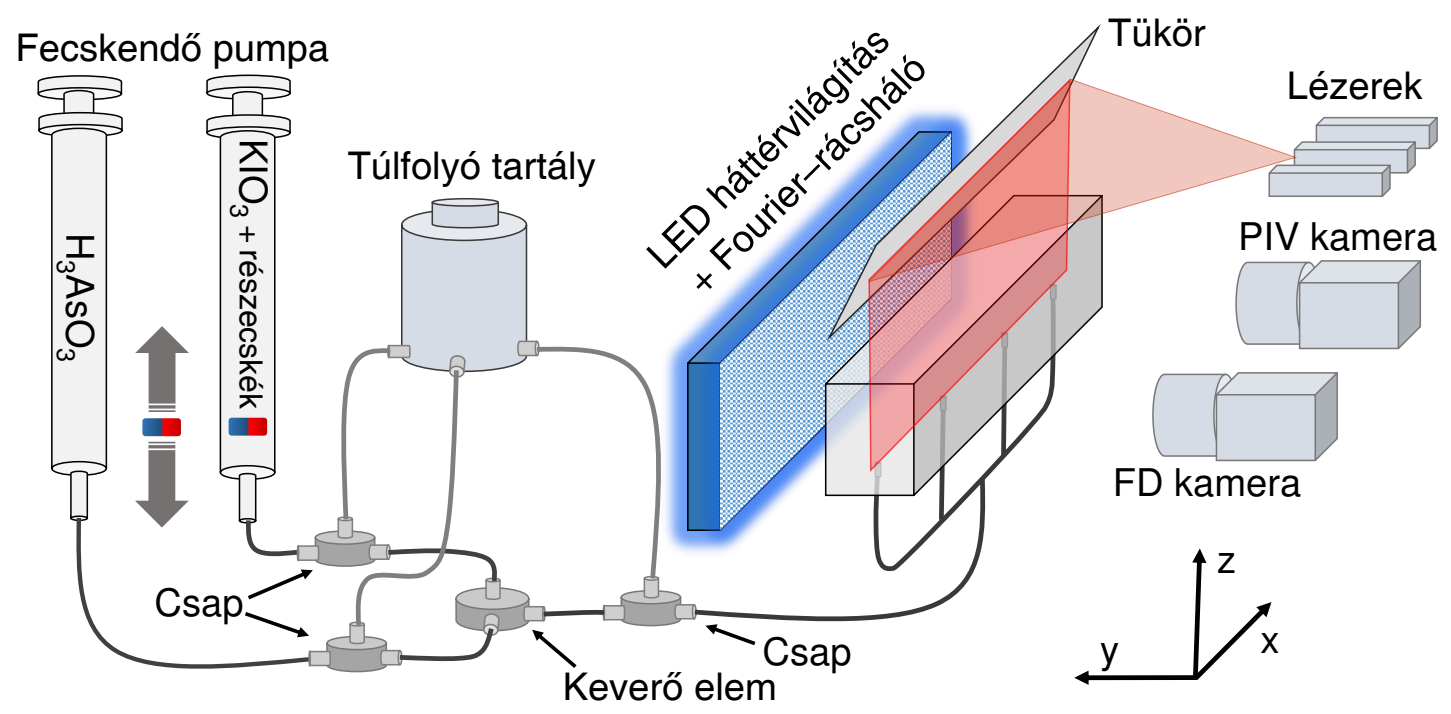

4.5. ábra. A rakétakísérlet során alkalmazott kísérleti elrendezés sematikus ábrázolása. 
A cellák töltése automatikusan történt egy szekvenciának megfelelően egy bizonyos térfogatig a mikrogravitációs fázis elérése után. A töltés során a fecskendők tartalma egy keverő egységen áthaladva keveredett össze 1:1 arányban. Az töltés és keveredés során esetlegesen kialakuló buborékok cellába jutását két, úgynevezett előtöltési fázis beiktatásával küszöböltük ki. Ennek során a fecskendőkből először kilépő kis oldatrészleteket csapokon keresztül afelé a tároló felé vezettünk, melyet a hidraulikus kör mosása során használtunk a felesleges oldat elhelyezésére. Ugyanezt a folyamatot megismételtük, a keverőelemen átáramlott, már összekeveredett reaktáns oldatrész kis mennyiségével is. Megállított áramlás mellett, a szelepet a cellák irányába állítottuk majd folytattuk a töltést. A reaktánsoldat a cellák alján 4 ágon keresztül került bevezetésre. Az automatikus töltés befejezése után manuálisan fejeztük be a töltést egy grafikus felületet használva viszonylag lassú töltési sebesség mellett. A töltést két operátor végezte, az egyikük a töltésre vonatkozó parancsot adta ki a cellák állapotáról élőben sugárzott képek alapján, a másik operátor pedig az utasításait követte. Erre azért volt szükség, hogy teljes bizonyossággal görbületmentes folyadék-gáz határfelületet tudjunk kialakítani. A cella belsô peremig történő feltöltése után az automatikus vezérlésbe néhány másodperces késleltetés volt idôzítve, hogy a reakció iniciálása előtt a folyadékmozgás megszúnjön a cellákban. A késleltetés után a vezérlés 4 másodperc időtartamig $5 \mathrm{~V}$ nagyságú feszültséget kapcsolt a platina szálakra, elindítva a reakciót. Arról, hogy az elektrolízis sikeresen megtörtént az fémek felületén megjelenő buborékok adtak visszajelzést.

A reakció lejátszódása során a reakciófront alakjának és térbeli helyzetének változását úgynevezett Fourier-deflektometriás technikával követtük cellánként egy-egy kamerával. A cellatöltés során is ezt a kamerát használtuk a folyadékszint nyomon követésére. A termék oldatrész kontrasztosabb megjelenítéséhez egy 475 nm hullámhosszú kék LED háttérvilágítást alkalmaztunk, mivel a reakció során keletkező jód sárga színének ennél a hullámhossznál van a legnagyobb elnyelése. A LED háttérvilágításra ráépítésre került egy négyzetrácsos rácsháló mintázat, melyet a kiértékelés során használtunk fel. A kamera és a cella különböző lencsék kerültek beépítésre, amelyek a lehető legjobb képalkotáshoz voltak szükségesek. A kamera másodpercenként 30 tömörítés mentes képfelvételt készített 1920 képpont $\times 640$ képpontos felbontással és 10 bit-es színmélységgel.

A reakció során kialakuló folyadékmozgás megjelenítésére és követésére a részecskeképen alapuló sebességmeghatározás (PIV) technikát alkalmaztuk. Ennek lényege, hogy apró, esetünkben 6,4 $\mu \mathrm{m}$ átmérőjű, nem ülepedő fényszóró részecskéket juttatunk a folyadékba, melyeket lézerrel megvilágítva követünk egy fotósorozaton keresztuil. A módszer nagy előnye, hogy nem intruzív, tehát semmilyen módon nem befolyásolja a folyadékáramlást. $250 \mathrm{~cm}^{3}$ jodát törzsoldat elkészítésekor $180 \mu$ térfogatú, 10 tömegszázalékos, PIV szuszpenziót adtunk a jodát oldathoz, hogy az $72 \mu \mathrm{g} / \mathrm{cm}^{3}$ koncentrációban tartalmazza a PIV részecskéket. A részecskéket tartalmazó fecskendőkbe mágneses keverốknél használt kis 
mágneses rudakat helyeztünk. Szerepük a hosszabb várakozás, illetve a kilövés során ható 7-10 g nagyságú gyorsulás hatására esetlegesen leülepedő részecskék eloszlatása volt az oldatban. A keverést egy, a rakéta hossztengelye mentén alternáló mozgást végző mechanizmus végezte, amely a két PIV részecskét tartalmazó fecskendő közé volt építve és amely végére egy mágnes volt rögzítve. A folyadékmozgás három dimenzióban való követésére három egymással párhuzamos $0,5 \mathrm{~mm}$ szélességû $600 \mathrm{~nm}$ hullámhosszúságú lézernyalábot használtunk az xz-síkban a cella hossztengelyével párhuzamosan. Egy lézer a cella középvonalára volt pozicionálva, míg a másik kettő 1,5-1,5 mm távolságban el volt tolva az y-tengely mentén. A lézernyalábok így három sík mentén függőlegesen világították meg a részecskéket. A lézereket a modul vezérlése egy szekvenciának megfelelóen kapcsolta ki, illetve be. A lézerek világításának szekvenciáját a két cellában a 4.6. ábra mutatja. A PIV rendszer

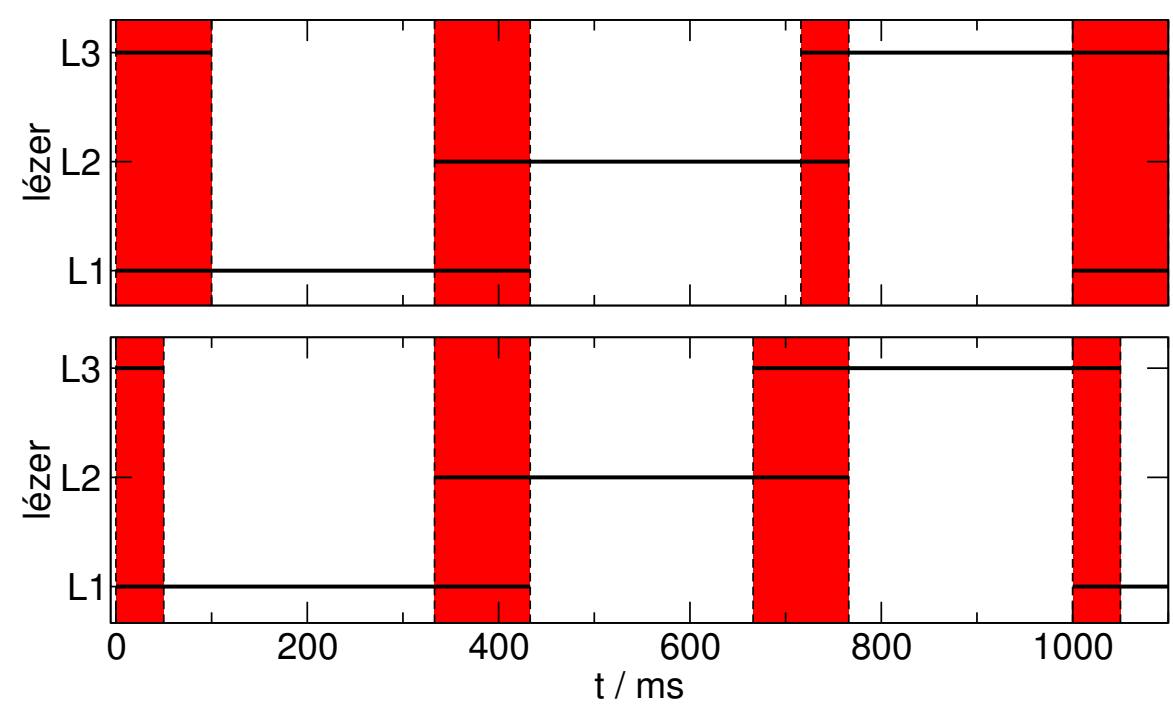

4.6. ábra. A lézersíkok világítási szekvenciája.

kamerái elé egy színszűrő került beépítésre annak érdekében, hogy a LED háttérvilágítás fénye ne, csak a lézernyalábok hullámhosszával egyező fény jelenjen meg a PIV felvételeken. Mindkét rendszer kamerája a mikrogravitációs fázis elérésekor lett bekapcsolva és az adatrögzítés is ekkor indult. 


\section{Kiértékelési módszerek}

\subsection{Frontalak, frontsebesség meghatározása}

A reakciófront alakjának, helyének tér- és időbeli változását minden esetben az elkészült kísérleti felvételek segítségével határoztuk meg. Mind a parabolarepülés mind a rakéta kísérletek során monokróm CCD kamerával rögzítettünk képfelvételeket. A parabolarepülés során DALSA DS-21-02M30 típusú kamerával készítettünk 800 képpont $\times 598$ képpont méretû 8 bit színmélységú felvételeket. Egy képpont így 256 árnyalatot tud felvenni, ahol a 0 érték a feketének a 255-ös érték a fehérnek felel meg. A rakétakísérlet során ADIMEC A2000/m típusú kamerával 1920 képpont × 640 képpont méretú felvételeket rögzítettünk. Ezen felvételek 10 bites színmélységgel készültek, ez esetben a pixelek értéke 0 és 1023 között változhat a kis intenzitástól a nagy intenzitás felé. A IAA reakcióban megfelelő $R$ érték esetén a keletkező jód sötét színe kontrasztosan kirajzolja a termékoldatrész eloszlását a reakcióedényben mely kifejezetten hasznos, hiszen nem szükséges indikátor használata. Maga a front a két oldatrészt elválasztó éles határvonal. Ez a határvonal a kísérletek során készített fekete-fehér fotókon a sötét színből a világos színbe történő átcsapás helye. Ennek meghatározására a szürkeségi skála mezőben a pixelek által felvett értékek deriváltjának maximumát kerestem meg és ábrázoltam mind függóleges mind vízszintes irányban a felvételeken. Ezzel a módszerrel a front alakja a képsorozatok minden elemén kirajzoltatható. A front előrehaladását két kép között eltelt idôtartam alatt így képpont mértékegységben tudtam meghatározni. Az elmozdulás valós távolságban történő megadáshoz kalibrációval történő konvertálás volt szükséges. Ezt a kalibrációt minden képsorozaton elvégeztem a front jellemző terjedési irányába. A parabolarepülés során készült felvételek esetén az $x$-tengely irányában míg a rakétakísérlet felvételein, mind az $x$-, mind pedig a $z$-tengely irányába végeztem kalibrációt. A kísérletre jellemző milliméterenkénti képpontszám és a két kép készítése között eltelt idő ismeretében a font terjedési sebessége könnyedén meghatározható. Ábrázolva a front adott szakaszának átlagos pozícióját az idő függvényében, a kapott pontsorozat meredeksége adja a front terjedési sebességét.

A rakétakísérlet során a frontalak tér- és időbeli változásának rögzítésére a Fourierdeflektometriás technikát alkalmaztuk mely a kamerán kívül egy úgynevezett Fourier-rácshálót tartalmazott a LED háttérvilágítás és cella közé építve. Az $x z$-síkban $45^{\circ}$-ban elforgatott négyzetes rácsháló mintázatának hullámhossza $\sim 10$ képpont és a kiértékelés során ez a mintázat mint vivőfrekvencia volt felhasználható. Az elkészült felvételek így a következő 
függvénnyel írhatók le

$$
g(x)=b(x)\left(\frac{a \cos \left(2 \pi \frac{x}{\lambda}+1\right)}{2}\right)+z(x)
$$

ahol $b$ a rendszer abszorbanciája, $a$ a rácshálót leíró intenzitásfüggvény és $\lambda$ a rácsháló mintázatának hullámhossza. A fenti egyenletet komplex alakba írva az alábbi formát kapjuk:

$$
g(x)=b^{\prime}(x) \frac{\left(e^{2 \pi f_{0} x i}+e^{-2 \pi f_{0} x i}\right)}{2}+z^{\prime}(x)
$$

ahol $f_{0}$ a mintázat frekvenciája, mint vivőfrekvencia szerepel. A függvény Fourier-transzformációjának eredménye:

$$
G(f)=\frac{1}{2} B\left(f-f_{0}\right)+\frac{1}{2} B\left(f+f_{0}\right)+Z(f) .
$$

Ahol akár a $B\left(f-f_{0}\right)$ akár a $B\left(f+f_{0}\right)$ tagot is felhasználhatjuk a következő lépésben, amely során a Fourier spektrum középpontjából $+f_{0}$ vagy $-f_{0}$ távolságra található részét transzformációval az origóba toljuk. Ezen lépés során kiszúrjük a különböző zajokat és számunkra nem fontos információt tartalmazó $Z(f)$ tagot. Az így kapott spektrumon inverz Fouriertranszformációt végezve visszakapjuk a számunkra fontos információt hordozó tagot:

$$
\frac{1}{2} B(f) \Longrightarrow \frac{1}{2} b^{\prime}(x)=\frac{b(x) a}{4} .
$$

Az eljárás végén, egy kontrasztosabb, háttérmintázat mentes felvételt kapunk. A folyamat során felhasznált kísérleti fotót és a végeredményként kapott képet az 5.1a. és az 5.1b. ábra mutatja. Magát az algoritmust optikai elemek (lencsék, szúrôk) felületén található in-
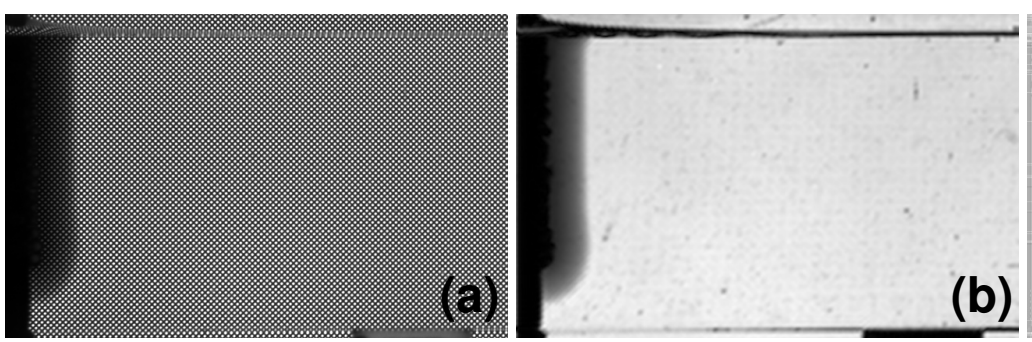

5.1. ábra. A Fourier-deflektometriás eljárás során felhasznált kísérleti felvétel (a), a kapott háttérmintázat mentes fotó (b) és a törésmutató homogenitását bemutató fáziseloszlás ábra (c).

homogenitások nagy pontosságú kimutatására dolgozták ki. Ugyanis a számítás során nem csak az intenzitás értékek nyerhetők ki a háttérmintázat felhasználásának segítségével, hanem törésmutatóbeli változások is. Optikai elemeknél ez felület geometriai hibáiból, topog- 
ráfiai eltérésekből adódóan változhat. A törésmutatóbeli eltérések optikai törést, torzítást okoznak melynek az eredménye a háttérmintázatban bekövetkező fáziseltolódás, melynek értékét szintén kinyerhetjük az algoritmus használatával (az 5.1c). Esetünkben ilyen fáziseltolódást a folyadék törésmutatójában bekövetkezô változások okozhatnak, melyek forrása a hőmérsékletben vagy az összetételben kialakuló lokális inhomogenitások lehetnek. Azonban a kísérlet során mind az összetétel-, mind a hőmérséklet-változásból adódó eltérések minimálisak voltak. A technika alkalmazásának oka elsôsorban az volt, hogy biztosítsuk a lehetôségét annak, hogy bármilyen nem várt jelenség esetén tudjuk ellenőrizni az oldatbeli hőmérséklet-eloszlás homogenitását.

A parabolarepülés, illetve a földi referencia mérések során készült felvételek esetén a frontsebességet a kialakult ujjas alak csúcsának átlagos pozíciójából számítottam ki. A rakétakísérletek során a Fourier-deflektometriás eljárással átalakított képeken (az 5.1b) több $z$-koordináta mentén és több irányban is meghatároztam a terjedési sebesség értékét, mivel a front geometriájából adódóan, több eltérő terjedési sebességgel rendelkező karakterisztikus terjedési irány volt jellemzô.

\subsection{Sebességmeghatározás a folyadékban}

Az indukált folyadékáramlásra jellemző áramlási sebességek meghatározására két módszert használtam. Az első az úgynevezett részecskeképen alapuló sebességmeghatározás (angolul Particle Image Velocimetry - PIV) módszere a teljes áramkép meghatározására alkalmas. A módszer lényege, hogy a két eltérô idôpontban képen, amelyek közötti elmozdulást szeretnénk meghatározni, kijelölünk egy mintázási területet, amely elhelyezkedése a két képen azonos. Szürkeségi skála értékek alapján a területeket leíró két kétdimenziós függvényt képezzük, majd vizsgáljuk ezek hasonlóságát. A hasonlóság vizsgálatát a jelfeldolgozásban gyakran használt keresztkorrelációs függvény számításával tudjuk elvégezni az (5.5) alapján:

$$
\phi_{f g}(x, y)=f \circ g=\sum_{m=0}^{M-1} \sum_{n=0}^{N-1} f(m, n) g(x+m, y+n) .
$$

Ahol $g$ a $t$ idôpontban, $f$ pedig a $t+d t$ idôpontban készített felvételek $M$ képpont $\times N$ képpont nagyságú részterületeit leíró függvények, és $x=0,1, \ldots, M-1$ és $y=0,1, \ldots, N-1$. Ezzel az eljárással gyakorlatilag azt határozzuk meg, hogy két függvény között mekkora tér vagy időbeli eltolás esetén legnagyobb a korreláció. A számítások elvégzésére több eljárást is kidolgoztak [73]. Kis számítási igénye és egyszerú implementálhatósága miatt csoportunkban korábbi munkák során a gyors Fourier-transzformáción alapuló módszert használták. A 
módszer a keresztkorrelációs-tétel alapján határozza meg a keresztkorrelációs függvényt:

$$
f(m, n) \circ g(m, n) \Leftrightarrow F(\xi, \eta) G^{*}(\xi, \eta)
$$

ahol $F$ az $f$ függvény Fourier-transzformáltja és $G^{*}$ a $g$ függvény Fourier-transzformáltjának komplex konjugáltját jelenti. A folyamat szemléltetésére az 5.2. ábrán bemutatott két mesterségesen előállított fotón is elvégeztem a kiértékelést. Ezt a képpárt felfoghatjuk úgy, mint egy PIV mérés során adott időkülönbséggel készült két felvétel azonos részterületei. Az el-
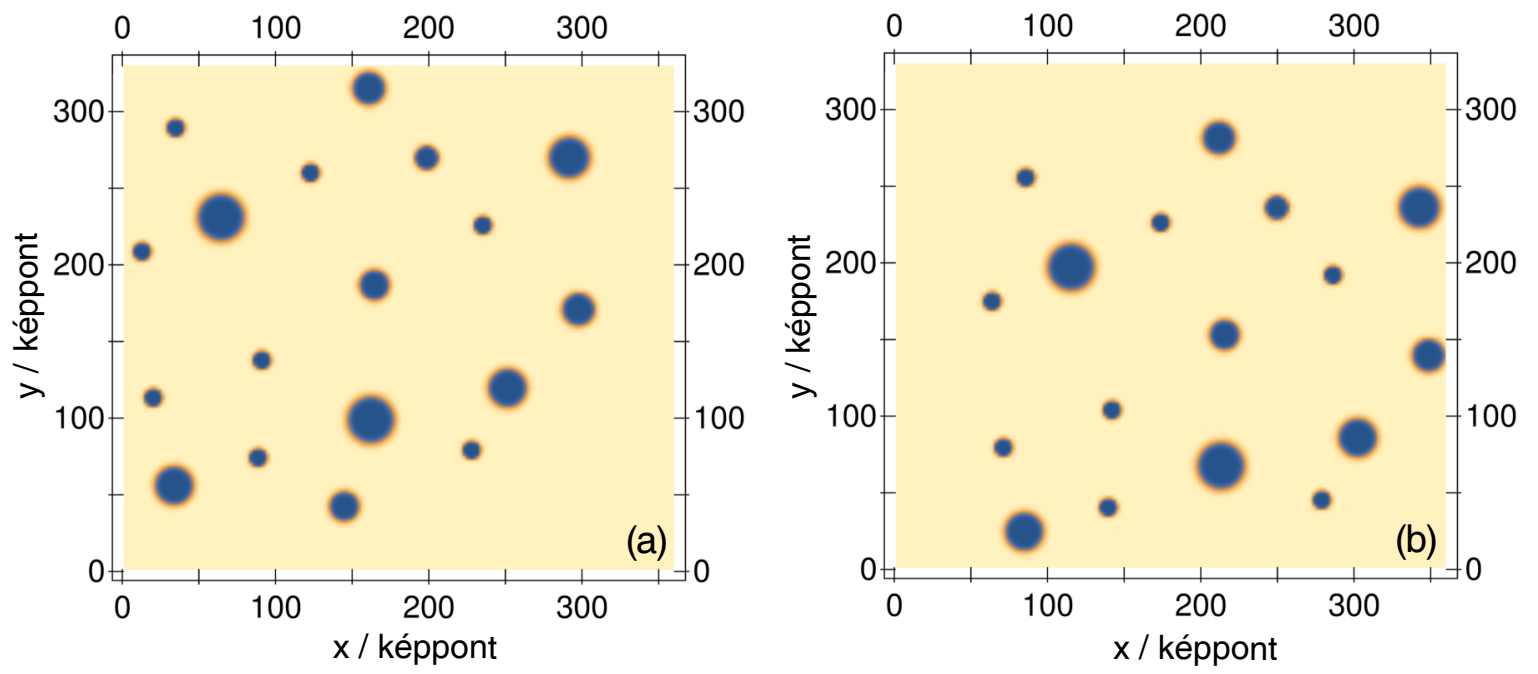

5.2. ábra. A kép bal felsô sarka felől a jobb alsó sarok felé történő elmozdulást szimuláló, mesterségesen előállított részecskeképek.

telt idő alatt az ábrázolt 18 részecske $\sim 55$ képpontnyit jobbra és $\sim 35$ képpontnyit lefelé mozdul el a kiválasztott területen. Elvégezve az (5.6) egyenletben leírt eljárást az 5.3. ábrán látható keresztkorrelációs függvényt kapjuk, melynek maximumának helye adja a $\vec{z}$ elmozdulásvektor komponenseit. Azonban a Fourier-transzformáció sajátossága, hogy a bemeneti adatokat folytonos függvénynek tekinti és az eredményként kapott függvény is folytonos függvény lesz. Ez azt eredményezi, hogy a kapott adatsor adatpontjai nem a megszokott sorrendben követik egymást és két dimenziós ábrázolás során a koordináta-rendszer térnegyedei felcserélődnek. Szemléletesebb ábrázoláshoz olyan transzformációt kell végrehajtani a kapott adatsoron, hogy a térnegyedek megfelelő helyre kerüljenek. A transzformáció eredményeként kapott függvény az 5.3. ábrán látható, és a maximumának helye már a valódi elmozdulásnak megfelelő koordinátákkal rendelkezik, amely így a $(52,-32)$ vektort adja. Ha adott a két kép közötti idôkülönbség akkor ebből megkapjuk az adott képrészleten a részecskék elmozdulásának irányát és sebességét képpont/idő mértékegységben, melyet kalibrációval távolság/idő mértékegységbe könnyedén átszámolható.

Mindkét cella esetén azokat a kísérleti felvételek használtam, amelyeken a cella közép- 


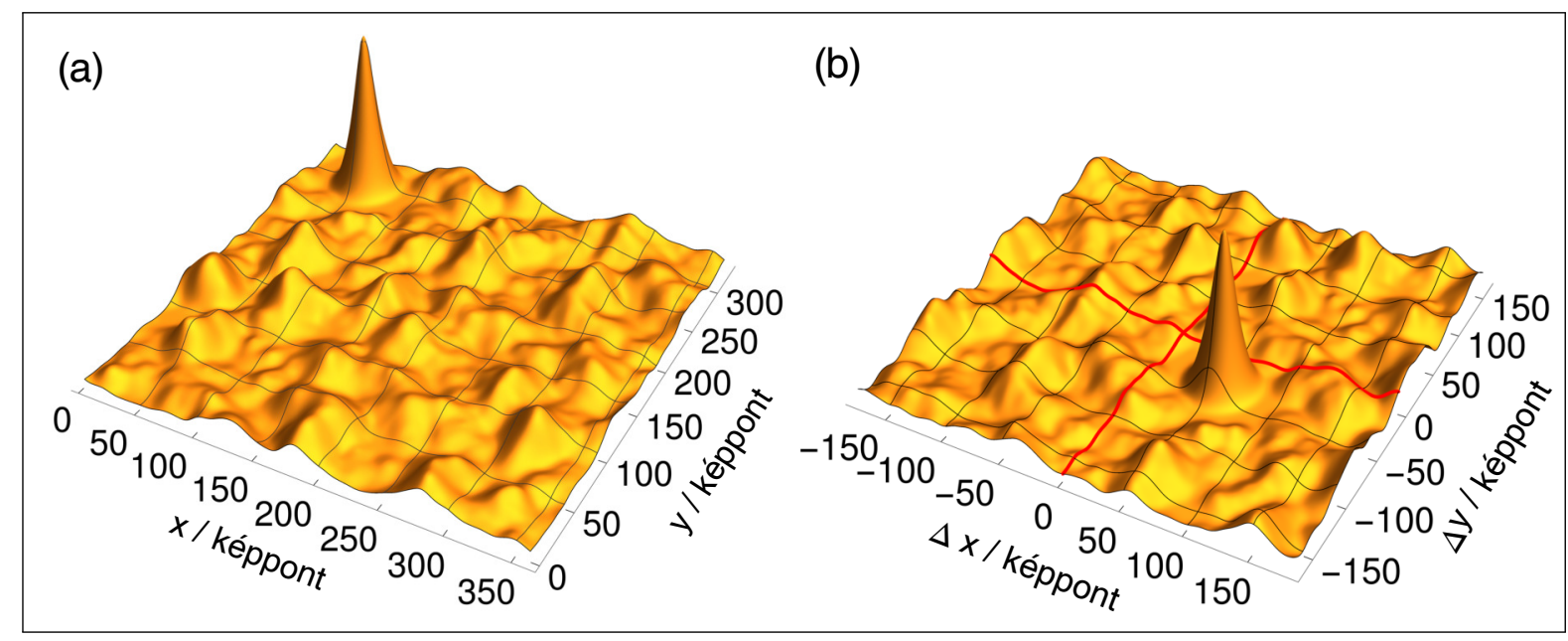

5.3. ábra. A bemutatott eljárással kapott keresztkorrelációs függvény (a), illetve a korrelációs függvény transzformált alakja (b).

vonalát megvilágító lézer volt bekapcsolva. A felvételeken 64 képpont $\times 64$ képpontos rácshálónak megfelelő mintázási területeken végeztem el a kiértékelést, lefedve a teljes felvételt. A kiértékeléshez egy, a kutatócsoportunkban írt, és korábbi munkák során sikerrel használt programmal végeztem. A program múködésének lényege, hogy ha adott a kiválasztott két kép, vagy képsorozat, amelynek ismert a kezdő és végső képe, illetve a növekmény a képek számában, akkor kiszámolja a keresztkorrelációs függvényt.

A PIV mérések során a keresztkorrelációs számításhoz kiválasztott két kép között eltelt időnek nagy jelentősége van. Túl kicsi idôkülönbség esetén nem látunk elmozdulást, túl nagy időkülönbségnél pedig előfordulhat, hogy a részecskék kiúsznak a kiválasztott területről, amely szintén nem valós adatokat eredményezhet. Ráadásul, mivel a keresztkorrelációs számításnál a képrészleteket periodikus függvényeknek tekintjük, a részecskék nem tehetnek meg nagyobb távolságot, mint a részterület oldalának a fele, ilyen esetben ugyanis az elmozdulás értéke negatív előjelet kap. Számos tanulmány foglalkozott a keresztkorrelációs PIV technika optimalizációjával és többen ennél kisebb elmozdulás értékeket javasolnak $[74,75]$. A megfelelő elmozdulás-részterület élhosszúság arány alkalmazásához a kiértékeléshez használt két kép közötti időkülönbség csökkentésével vagy a részterület nagyságának változtatásával lehet eljutni. Túl nagy élhosszúság választásával azonban egy újabb probléma merül fel. Amennyiben az áramlási térben nagyobb sebességgradiensek vannak jelen - jellemzően fal melletti áramlás esetén - a keresztkorrelációs módszer ezeket nem fogja megjeleníteni, mert a legjellemzóbb elmozdulási irányt és nagyságot adja vissza a módszer az adott területen. Más szóval a módszer igen érzékeny olyan áramlásokra, melyekben nagyobb nyírás jellemző.

A folyadék-gáz határfelület közvetlen környezetében a folyadékáramlást egyéni részecskék mozgásának a vizsgálatával írtam le. Ennek elvégzéséhez az úgynevezett egyéni részecs- 
kekövetésen alapuló sebességmeghatározás (Particle Tracking Velocimetry - PTV) módszerét alkalmaztam. Ezen eljárás a részecskék mindenkori pozíciója meghatározható, így a részecskék által bejárt utat is megkapjuk a sebesség mellett. A kiértékelést ugyanazokon a kísérleti felvételeken el tudtam végezni, amelyeken magát a PIV méréseket is elvégeztem, a technika nem igényelt semmi féle konvertálást vagy módosítást a fotókon. Ennél a technikánál azonban már egy 254 darab képből álló 311 másodperc időtartamod átfogó képsorozaton kellett a kiértékelés végezni szemben a PIV technika 2 fotójával. A kiértékelést az ImageJ képfeldolgozó programhoz, a svájci MOSAIC group által kifejlesztett szabad hozzáférésú MosaicSuite nevú kiegészítő programcsomagjával végeztem [76]. A számoláshoz a következő paraméterek felhasználó általi megadása szükséges: részecske sugár $(w)$, küszöbérték $\left(T_{S}\right)$, percentilis $(r)$, maximális elmozdulás $(L)$ és az úgynevezett kapcsolási tartomány $(R)$. Az eljárás minden egyes bemeneti felvétel képpontjainak intenzitását normalizálja, hogy kiküszöbölje a felvételek készítése során bekövetkezô esetleges háttérintenzitás-változásokat. A részecskék sugarát a felhasználónak pixelben kell megadnia és javasolt, a jellemző részecskesugárnál minimálisan nagyobb értéket megadni. A $w$ értéke az algoritmusban több helyen is felhasználásra kerül. Meghatározó szerepe van például a részecskék háttértől való elkülönítésekor használt összefüggésekben, ahol az eljárás egy $2 w+1$ oldalhosszúságú négyzet alakú területen átlagolja a normalizált intenzitásértékeket. A részecskék helyének meghatározásához az $r$ érték megadása is szükséges. Az algoritmus azon képpontokat jelöli ki részecskének, amelyek környezetében $w$ távolságra nincs fényesebb pont, illetve a képpont értéke az aktuális felvétel intenzitás értékeinek a felsô $r$. percentilisébe esik. Az én esetemben az egyéni részecskék mérete a kísérleti fotókon jellemzően 2 képpont $\times 2$ képpont volt, és a nagyobb aggregátumok átmérője sem haladta meg a 3 képpontot. Részecskesugár értéknek 1 képpontot adtam meg és a részecskedetektáláshoz a felsô elsô percentilisbe esô képpontokat vettem figyelembe az $r=1$-nek megfelelően. A program klaszteranalízis alkalmazásával képes elkülöníteni a fókuszból kiesố részecskéket, az optikai elemeken, illetve a vizsgált közegben jelenlévő szennyeződéseket a vizsgálat szempontjából fontos részecskéktől. A statisztikai elemzés során az algoritmus a részecskék intenzitáseloszlásának nulladés másodrendû́ momentumát ( $m_{0}$ és $m_{2}$ ) határozza meg. Ezek rendre az intenzitásértékek összege az adott részecske területén, illetve a részecske intenzitásának két dimenziós eloszlása, mely a részecske alakjáról ad információt. Majd ebben a kétdimenziós térben elhelyezi a pontokat. A valós részecskék egy klasztert alkotnak és elkülönülnek az eltérő alakú és méretû részecskéktől. A klaszterbe tartozó pontok lehatárolásához a $\left(T_{S}\right)$ küszöbérték megadásával történik. Amennyiben a részecskék alakja és fényessége nem változik a felvételeken a klaszter tagjai nem mozdulnak el az $\left(m_{0}, m_{2}\right)$ térben -, a küszöbérték hangolásával jól elkülöníthetôk a valóban fókuszban lévő, illetve azonos alakú részecskék a fókuszon kívül esô és a vizsgált részecskéktől eltérő alakú szennyeződésektől. Biológiai minták vizsgálatánál 
- amire az algoritmus eredetileg megalkotásra került - ennek kiemelt jelentősége van, esetemben azonban az aggregátumok forgó mozgása és becsillanása miatt, mind a részecskék intenzitása, mind pedig alakja változott a kísérlet során. Így a $T_{S}$ értéket a készítők ajánlásának megfelelően, az alapértelmezetten alacsony 0,6-es értéken hagytam. A részecskék kiválasztása után, a részecskék követéséhez két további paraméter megadására van szükség. Ezek alapján tudja a program a különböző felvételeken azonos paraméterek mellett detektált részecskéket beazonosítani és az elmozdulásukat meghatározni. Az egyik ilyen érték az általam kapcsolási tartománynak nevezett $R$ amellyel a felhasználó azt határozza meg, hogy egy számítási lépésben hány egymást követô felvételen párosítsa a részecskéket az algoritmus a képsorozaton belül. A másik paraméter $(L)$ a két időben egymást követő felvételen a részecskék maximális elmozdulását adja meg. A számítások során az $R=5$ és $L=3$ értékeket alkalmaztam a részecskék azonosításához és képsorozaton belüli összekötéséhez. A különböző lépések részletes leírása az eljárást leíró közleményben megtalálható. Látható, hogy a számítás pontosság legalább 5 a felhasználó által megadandó szubjektív paramétertől függ, továbbá a pontosságot nagy mértékben befolyásolja az elkészült felvételek minôsége, az eltűnő, a megjelenő, illetve becsillanó részecskék mennyisége. A program futtatása után a részecskék számított pályája megjelenítésre kerül, és ellenőrizhetô azok helyessége. Néhány próbaszámítást követően sikerült a megfelelő értékek meghatározása így, bár nem nagy számban, de elfogadható mennyiségben sikerült olyan részecskéket találnom mindkét cella esetében, amelyek a kísérlet teljes időtartamában követhetôk. A kiértékeléshez használt számítás során meghatározott néhány megjelenített trajektória látható a képsorozat utolsó felvételén az 5.4. ábrán.

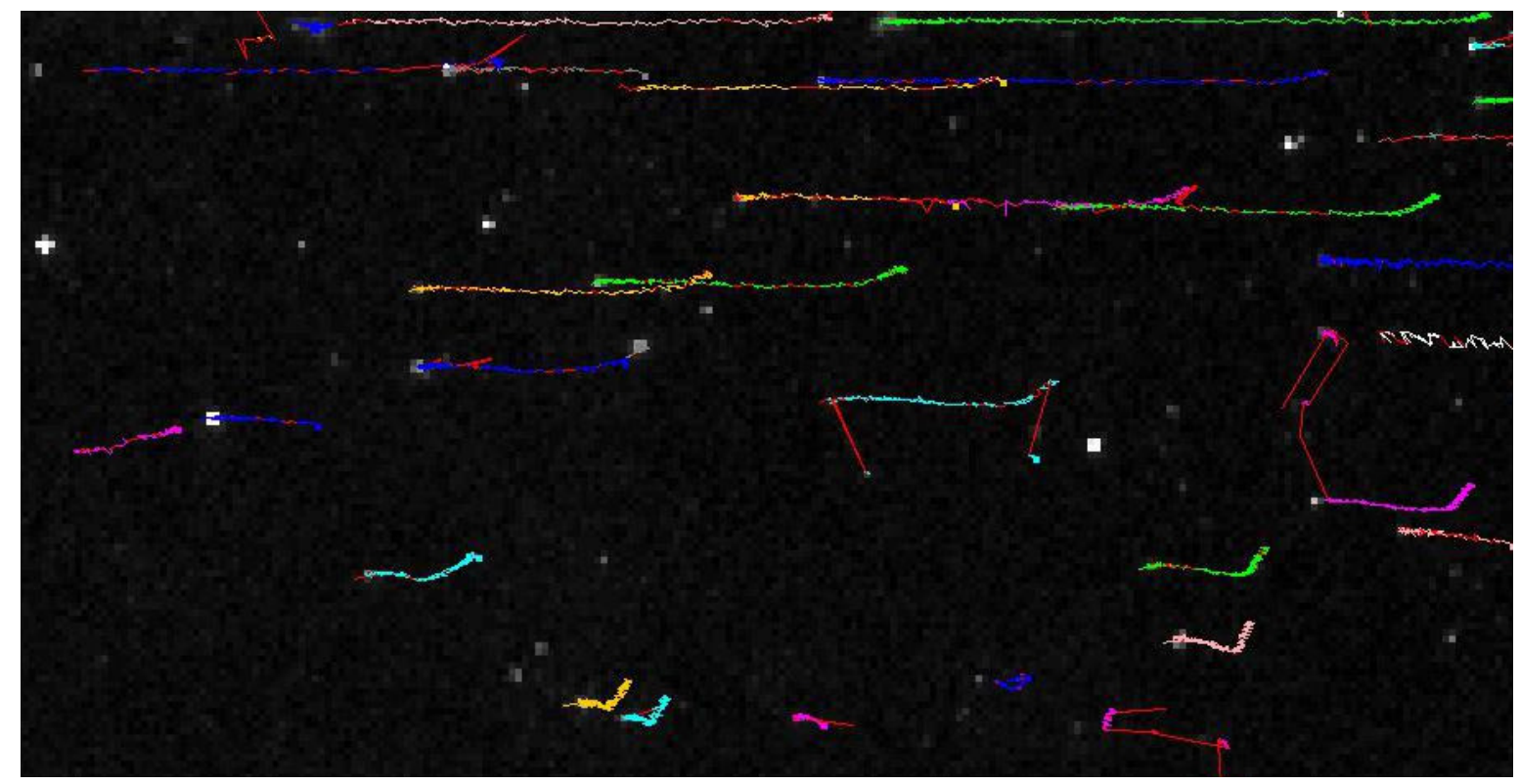

5.4. ábra. A PTV módszerrel meghatározott részecske trajektóriák. 
A számolás végeredményeként megkapjuk a követett részecskék mindenkori koordinátáit a képsorozat minden egyes felvételén. Ismerve a felhasznált fotók közötti időkülönbséget, a részecskék sebességét is ki tudjuk számítani. 


\section{Numerikus modellezés}

Az elméleti fluiddinamikai számítások legfőbb és leghatékonyabb eszköze napjainkban a numerikus szimuláció. Az áramlástani modellezés során a vizsgált közeg áramlási terét határozzuk meg a megmaradási egyenletek numerikus megoldásával. A megmaradási egyenletek a megoldandó feladattól függôen az impulzus-, a tömeg- és az energiamegmaradás egyenletei lehetnek. A tömegmegmaradási egyenletet más néven kontinuitási egyenletnek nevezzük, és a fluidumok kontinuum jellegét fejezi ki vagyis azt, hogy egy adott térrész tömegének változása megegyezik a térrészbe beáramló, illetve kiáramló folyadékmennyiség különbségével.

$$
\frac{\partial \rho}{\partial t}+\nabla(\rho \vec{u})=0
$$

Az impulzus megmaradás tétele tulajdonképpen Newton II. törvényének felírása a folyadék vizsgált térfogatelemére, mely azt mondja ki, hogy a térfogatelemben lévő fluidum $m$ tömegére ható erốk összege a lendület idő szerinti differenciálhányadosával egyenlő:

$$
\sum \vec{F}=\frac{d(m \vec{u})}{d t}=m \vec{a} .
$$

A térfogatelem tömege: $m=\rho d x d y d z$, a gyorsulása pedig a sebesség $(u=u(t, x, y, z))$ teljes differenciálja. A ható erôk forrása a külső erôterekből (gravitáció, elektromos vagy mágneses erôterek) adódó úgynevezett tömegerők, illetve a térfogatelem felületeire ható erôk. A felületi erőket a 9 elemmel rendelkező $\overline{\bar{\tau}}$ feszültség tenzor írja le. A tenzor elemei $\tau_{i j}(i, j=1$, $2,3)$ az $i$ felszínen $j$ irányban ható erő komponensei. Az erónek ez alapján két összetevője van, az egyik a $\tau_{i i}$ vagyis felületre merôleges komponense, és a $\tau_{i j}$ felülettel párhuzamos nyírófeszüiltség a másik két irányban. A felületre merôleges nyomóerô legfőképpen a folyadékelem vagy gáz környezetéből származó nyomás, mivel a térfogatelemben ébredő belsô erők ilyen irányú komponense minimális. Ezek alapján a felületre ható eredô erő merőleges komponense:

$$
d \vec{F}_{\perp}=(-\nabla p) d x d y d z
$$

A felülettel párhuzamos erôt a nyírófeszültség és a felület szorzata adja. Ezen erők eredője:

$$
d \vec{F}_{\|}=(\nabla \tau) d x d y d z
$$

Egy felszínen adott nyírófeszültség nem más, mint az adott irányú impulzus áramsûrúsége a tömbfázis irányába. Az xy síkban a nyírófeszültség hatására elmozduló felszín és az alatta elhelyezkedő képzeletbeli fluidum lapok közötti sebességkülönbség miatt átadódó impulzus 
mennyisége közötti arányossági tényező a kinematikus viszkozitás (v):

$$
\tau_{31}=-v \frac{d\left(\rho u_{x}\right)}{d z}
$$

Ezek alapján a (6.4) egyenlet az alábbi alakban írható fel az összes lapon ható nyírófeszültségeket figyelembe véve:

$$
d \vec{F}_{\|}=\nabla(\rho \vee \nabla \vec{u}) d x d y d z=\nabla(\eta \nabla \vec{u}) d x d y d z
$$

ahol $\eta$ a fluidum dinamikus viszkozitása.

Az elemi térfogatra ható tömegerók eredôje $F_{a}=\vec{a} \rho d x d y d z$ ahol $\vec{a}$ általában a garvitációs gyorsulás $(\vec{g})$ amennyiben más erôterektől mentes térben áramlik a fluidum. Ennek megfelelően a vizsgált térfogatelemre ható eredő erő:

$$
d \vec{F}=(-\nabla p+\nabla(\eta \nabla \vec{u})+\rho \vec{g}) d x d y d z
$$

A (6.2) egyenlet felírásához így már csak a térfogatelem sebességének $(u=u(t, x, y, z))$ teljes differenciálját kell meghatározni. A térfogatelem sebességváltozása:

$$
d \vec{u}=\frac{\partial \vec{u}}{\partial x} d x+\frac{\partial \vec{u}}{\partial y} d y+\frac{\partial \vec{u}}{\partial z} d z+\frac{\partial \vec{u}}{\partial t} d t .
$$

Mivel $d x=u_{x} d t, d y=u_{y} d t$ és $d z=u_{z} d t$, ezért

$$
d \vec{u}=\frac{\partial \vec{u}}{\partial x} u_{x} d t+\frac{\partial \vec{u}}{\partial y} u_{y} d t+\frac{\partial \vec{u}}{\partial z} u_{z} d t+\frac{\partial \vec{u}}{\partial t} d t .
$$

A (6.9) tagjait leosztva $d t$-vel megkapjuk a sebességváltozás sebességét:

$$
\vec{a}=\frac{d \vec{u}}{d t}=u_{x} \frac{\partial \vec{u}}{\partial x}+u_{y} \frac{\partial \vec{u}}{\partial y}+u_{z} \frac{\partial \vec{u}}{\partial z}+\frac{\partial \vec{u}}{\partial t}=\frac{\partial \vec{u}}{\partial t}+\vec{u}(\nabla \vec{u}) .
$$

A (6.2) egyenletbe behelyettesítve a (6.7) egyenletet és a (6.10) egyenlet legutolsó alakját az alábbi egyenletet kapjuk:

$$
\rho\left(\frac{\partial \vec{u}}{\partial t}+\vec{u}(\nabla \vec{u})\right) d x d y d z=(-\nabla p+\nabla(\eta \nabla \vec{u})+\rho \vec{g}) d x d y d z .
$$

Ezt az egyenletet Navier-Stokes egyenletnek nevezünk.

Adott peremfeltételek mellett a megoldandó problémától függően a (6.1) és a (6.11) egyenletek megoldása már elegendő, hogy megkapjuk a jellemző sebesség- és nyomáseloszlást a modellezett térrészben. Ez a két egyenlet tehát alapvető fontosságú, megoldásuk nélkül nem tudjuk leírni a folyadék mozgását. Az energiamegmaradás egyenleteinek meg- 
oldására izotermikus áramlás esetén nincs szükség. A szimulált feladattól függóen számos egyszerúsítés alkalmazható, melyek bevezetésével nem feltétlenül egyszerúsödik az egyenletek megoldása, de a számítási igény vagy más néven a számítás idôtartama lerövidíthető. Például folyadékáramlás szimulációja esetén a folyadékok elhanyagolható összenyomhatósága miatt indokolt a sûrúség értékét konstansnak tekinteni. Ezt a megközelítést gyakran alkalmazzák gázok esetén is ha az áramlási sebesség nem haladja meg a Ma = 0,3-es értéket, ahol Ma a Mach-számot jelöli. Állandó hőmérsékleten a folyadék sưrúsége is állandó így a (6.1) az alábbi alakra egyszerúsödik:

$$
\nabla \vec{u}=0,
$$

amely egyben a sebesség mező divergencia mentességét is jelenti. Állandó sûrüséget feltételezve a (6.7) egyenlet jobb oldalán a sűrúség kiemelhetô és $m$-el osztva a két oldalt az alábbi alakra módosul:

$$
\frac{\vec{F}}{m}=-\nabla \frac{p}{\rho}+v \nabla^{2} \vec{u}+\vec{g}
$$

A (6.13) egyenlet tehát az összenyomhatatlan, állandó hőmérsékleten áramló folyadék mozgását leíró alakja a Navier-Stokes egyenletnek.

Egy további igen gyakran alkalmazott egyszerűsítés a nem állandó hőmérsékleten áramló összenyomhatatlan folyadék mozgásának leírására kidolgozott Boussinesq-közelítés. A nem állandó hômérséklet miatt az egyébként összenyomhatatlannak feltételezett folyadékelem sűrűsége kizárólag a hőmérséklet változás hatására módosul, nyomás, illetve a nyíróerők miatt nem. Ebben az esetben a sûrúség csak a tömegerốt leíró tagban jeleneik meg:

$$
\frac{\vec{F}}{m}=-\nabla \frac{p}{\rho}+v \nabla^{2} \vec{u}+\frac{\rho_{k}}{\rho} \vec{g},
$$

ahol $\rho_{k}$ a térfogatelem sưrúsége a megváltozott hômérsékleten és amely értékét az alábbi összefüggés adja meg: $\rho_{k}=\rho\left[1-\alpha\left(T-T_{0}\right)\right]$. Ez a megközelítés teszi lehetôvé, hogy a sưrúségváltozásból származó természetes konvekciót is egyszerúen figyelembe vehetô. Azonban nem csak a hômérséklet-változás hatására változik a fluidum sưrúsége, hanem a kémiai reakciók során fellépő összetétel-változás miatt is. Így a térfogatelemben elhelyezkedő fluidum sûrúsége a jelenlévő összetevốk koncentrációjától függ az alábbi összefüggés alapján:

$$
\rho_{k}=\rho+\sum \rho_{i} c_{i}
$$

ahol $\rho_{i}$ az $i$-edik komponens sû́rúségváltozás összetétel szerinti tényezője $(\partial \rho / \partial c)$ lineáris kapcsolatot feltételezve. Az összenyomhatatlan de inhomogén összetételú folyadék áramlá- 
sát leíró egyenlet alakja tehát a következő:

$$
\frac{\partial \vec{u}}{\partial t}+\vec{u}(\nabla \vec{u})=-\frac{\nabla p}{\rho}+\nabla(\eta \nabla \vec{u})+\frac{\rho_{k}}{\rho} \vec{g}
$$

A fent említett probléma szimulációjához tehát a (6.12) és a (6.16) parciális differenciál egyenletek megoldása szükséges. Erre számos numerikus módszer létezik. A legelterjedtebbek azok a módszerek, melyek valamilyen diszkretizációs eljárást alkalmazva a differenciálegyenleteket algebrai egyenletekké alakítják és ezen egyenletekből álló egyenletrendszerek iteratív eljárásokkal közelítik a megoldást diszkrét térbeli pontokban. A diszkretizáció során a modellezett térrészt diszkrét térbeli elemekre bontjuk fel és minden ilyen úgynevezett kontroll térfogatra felírjuk - a diszkretizációs módszerre jellemző alakban - a transzportegyenleteket. Az algebrai egyenleteket mátrix alakban egy nagy egyenletrendszert alkotnak amelyet erre alkalmas eljárásokkal - például Gauss-eliminációval - már meg tudunk oldani. Diszkretizációs eljárásokból a legismertebbek a véges differencia, véges elemek és a véges térfogatok módszere. Fluiddinamikai számítások során ez utóbbit alkalmazzák a leggyakrabban azon pozitív tulajdonsága miatt, hogy mind globális, mind pedig lokális szinten konzervatív. Ez azt jelenti, hogy a megmaradási törvények nem sérülnek az egyenletek megoldása során, így viszonylag durva rácsháló esetén sem kapunk fizikailag értelmetlen megoldást. Ez a tulajdonság jól tükröződik az általános transzportegyenlet véges térfogat módszerben alkalmazott alakján is:

$$
\frac{\partial}{\partial t}\left(\int_{C V} \rho \phi d V\right)+\int_{A} \mathbf{n} \cdot(\rho \phi \mathbf{u}) d A=\int_{A} \mathbf{n} \cdot(\Gamma \operatorname{grad} \phi) d A+\int_{C V} S_{\phi} d V .
$$

Ahol $\phi$ a folyadékelem egy intenzív tulajdonsága $\mathbf{n}$ a felületről kifelé mutató normál vektor és $\Gamma$ a $\phi$ mennyiség diffúziós együtthatója. A (6.17) egyenlet bal oldalának második és jobb oldalának elsố tagján alkalmazásra került a divergencia tétel, melynek lényege, hogy adott mennyiség térfogati integrálját ki tudjuk fejezni a térfogatot határoló lapokon vett felületi integrálok összegével. Az elsô tag a $\phi$ teljes mennyiségének változásának sebességét adja meg a kontroll térfogatban, a második tag a $\phi$ konvekció hatására történő csökkenését írja le az adott térfogatelemben. A jobb oldalon $\phi$ diffúzió miatt bekövetkező növekedése és az esetleges forrásokban keletkező mennyiség $\left(S_{\phi}\right)$ található. Tekintettel arra, hogy a diffúzió során $\phi$ a negatív gradiens irányába mozdul el, a diffúzív tag cellába történő beáramlást jelöl. Tranziens (időben változó) probléma vizsgálatánál természetesen a tagok idô szerinti integrálását is el kell végezni. A véges térfogatok módszere tehát a Gauss-Osztrogradszkij-tétel alkalmazásával, a diszkretizáció során kapott kis térfogatelemekre írja fel a megmaradási törvények -folyadékáramlás esetén a Navier-Stokes egyenletek- integrál alakját, vagyis a fluxus mérleget. 
A modellezett térrész diszkretizációjával a differenciál egyenletek algebrai egyenletekké alakíthatók a szomszédos elemek segítségével. Két dimenzióban a szomszédos elemek száma négyre, míg három dimenzióban hatra nô és az algebrai egyenletekben is ennek megfelelôen növekszik a tagok száma is. Minden rácspontra annyi algebrai egyenletet kapunk, ahány változónak keressük a megoldását az adott pontban. Egy adott változóra felírhatjuk az alábbi egyenletet:

$$
\mathbf{A}[\phi]=b,
$$

melyben az A mátrix sorai egy-egy térfogatelemre kapott algebrai egyenlet együtthatóit tartalmazza, a $[\phi]$ a megoldásvektor, $b$ pedig a kezdeti értékeket tartalmazó mátrix. Ezt az egyenlet már többféle módszerrel megoldható, legegyszerúbb esetben például Gausseliminációval de legtöbbször valamilyen iteratív eljárást alkalmaznak.

A Reakció-diffúzió-advekció rendszerek szimulációja során a $\phi$ mennyiség szimulált térrészben történő mozgásának (transzportjának) teljes leírásához szükség van a sebességmező megadására. A sebesség értékek meghatározásához a Navier-Stokes egyenlet megoldására van szükség. Összenyomhatatlan folyadék áramlásának szimulációja esetén azonban ez komoly kihívást jelent. Ebben a formájában ugyanis az egyenletrendszerben a nyomás értékének meghatározásához szükség van a sebességértékekre, ugyanakkor a sebességértékek sem határozhatók meg a nyomásmező ismerete nélkül. Elsőre ez egy feloldhatatlan ellentétnek tûnik, azonban léteznek algoritmusok, melyek a tömegmegmaradás elvét kihasználva képesek a probléma kezelésére. Az ilyen eljárások közül a véges térfogat megoldókban a legtöbbet használt a SIMPLE (Semi-Implicit Method for Pressure-Linked Equations) [77] és a PISO (Pressure-Implicit Splitting of Operators) [78] eljárások ötvözéseként létrehozott PIMPLE (merged PISO-SIMPLE) algoritmus. A SIMPLE módszer állandósult lamináris áramlások vizsgálatára alkalmas, tehát idő szerinti deriváltakkal nem számol. A PISO algoritmus eredetileg nem iteratív módon adott megoldást tranziens áralmások vizsgálatára, azonban sikerrel adaptálták állandósult áramlásvizsgálatokhoz is. Mindkét módszerben közös, hogy egy feltételezett nyomásérték alkalmazásával implicit módon oldja meg a impulzus egyenletet (a linearizált algebrai egyenletrendszert), melynek eredményeként a sebességértékek is rendelkezésre állnak. A kapott sebességértékekkel interpolációs eljárásokkal, a cellákat elválasztó felületekre számított tömegáramok azonban nem elégítik ki a kontinuitási egyenletet. A tömegáramokban megjelenő egyenlőtlenséggel egy úgynevezett korrekciós egyenletben a kezdetben önkényesen választott nyomásérték korrigálható és egy következő iterációban már a valós értékhez közelebbi sebesség- és fluxusértékeket kapunk eredményül.

A linearizált algebrai egyetlenegyszer felírása a diszkretizációs eljárással válik lehetővé. A szimulációkban a rakétakísérletek során alkalmazott kísérleti geometriának megfelelő méretû́ rácsháló pontjaiban számoltam a szükséges változók értékeit. A rácshálókiosztásnál a szomszédos pontok közötti távolságok a következőképpen alakultak: $h_{x}=0,025 \mathrm{~mm}$, 
$h_{y}=0,5 \mathrm{~mm}, h_{z}=0,2 \mathrm{~mm}$, ugyanis ennél a elrendezésnél szúnt meg a kapott eredmények rácshálófüggése. A cellakiosztás $x$ és $y$ irányban izotróp, azonban $z$ irányba a csomópontok közötti távolság csökken. Az ilyen irányú sưrítésre azért volt szükség, mert az előzetes számítások alapján intenzív áramlás a folyadék-gáz határfelület közelében alakult ki, ennél fogva itt indokolt a szimuláció pontosságának növelése. A legutolsó cella magassága így a legelső celláénak ötöde. Természetesen az egyenletrendszer megoldhatóságát e módszer esetében is a kezdeti- és peremfeltételek biztosítják melyeket a 6.1 ábrának megfelelően állítottam be.

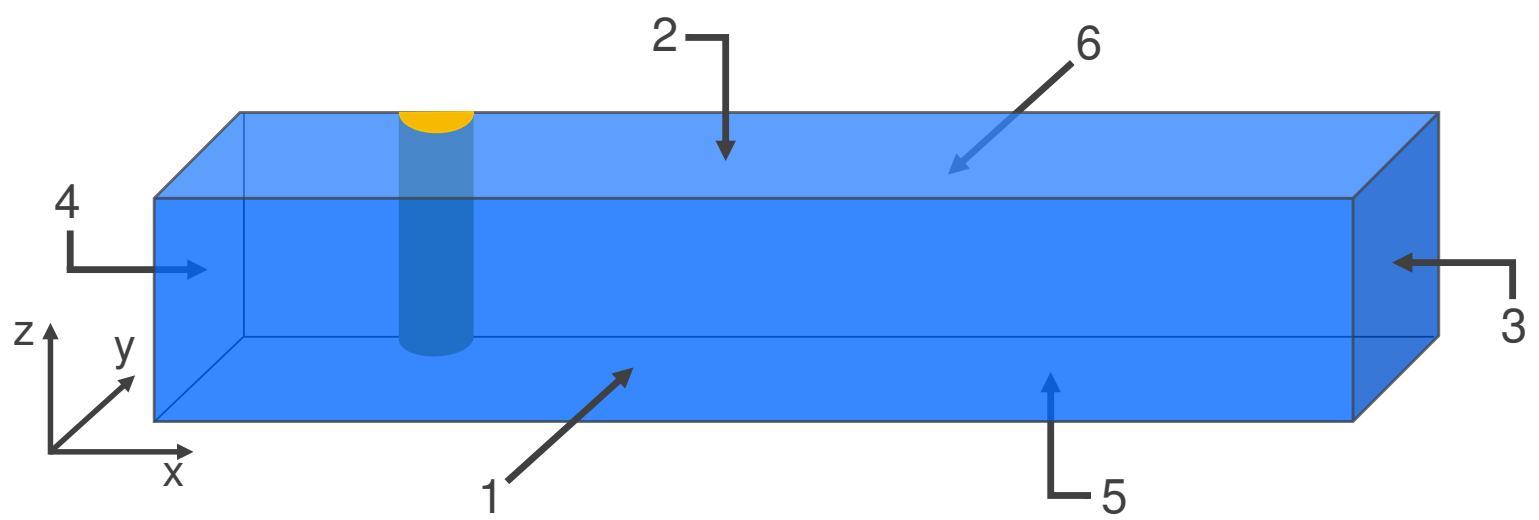

6.1. ábra. A termék (sárga) és a reaktáns (kék) oldatrészek elhelyezkedése a $t=0$ időpontban, illetve a geometriát határoló peremfelületek.

A sebességmező meghatározásánál a kezdeti értékeket nullának választottam a $t=0$ időpillanatban. Azon felületeken, ahol a valóságban a cella fala található (a 6.1 ábrán az 1, 3, 4 és 5 jelú felületek), rögzített 0 áramlási sebességet („no slip” feltételt) állítottam be peremfeltételként. A 2-es számmal jelölt felületen, amely a folyadék-gáz határfelületnek felel meg és ahol a Marangoni instabilitás kialakul, egy speciális peremfeltételt definiáltam. Ez a feltétel egy nyírási sebesség definiálása a felszínen, mely általánosságban az alábbi alakban írható fel:

$$
\frac{\eta \partial \vec{u}}{\partial z}=-M_{a} \nabla c_{i}=\frac{d \gamma}{d c_{i}} \nabla c_{i}
$$

A (6.19) egyenletben az $M_{a}$ az úgynevezett Marangoni-koefficiens, $\gamma$ a felületi feszültség értéke a folyadék-gáz határfelületen, $c_{i}$ pedig a felületaktív komponens koncentrációja. Így a felületen kialakuló folyadékmozgás nagysága a front mentén kialakuló koncentrációgradiens nagyságától, illetve a reakció lejátszódása során jellemző felületi feszültség változásának nagyságától és irányától függ. A modellszámítások során a Marangoni-koefficiens a valóságban mért értéknél $\left(3,6 \cdot 10^{-3}\right)$ egy nagyságrenddel kisebb érték $\left(1,2 \cdot 10^{-4}\right)$ esetén kaptam vissza a szimulációk eredményében a valóságban egyensúlyi rendszerben mért frontterjedési sebességértéket.

A számítások során a sebességértékek mellett meghatározásra kerültek a komponensek 
koncentrációértékei. A modell öt komponens, a jodátion, a jodidion, a trijodidion, a proton és az arzénessav koncentrációját és eloszlását reakció-diffúzió-advekció (RDA) rendszernek megfelelően, a következő mérlegegyenlet alapján számolja:

$$
\frac{\partial c_{i}}{\partial t}=D_{i} \nabla^{2} c_{i}-\vec{u} \nabla c+f_{i}
$$

amely egyenletben a $D_{i}$ a diffúziós együttható, $\vec{u}$ a közeg áramlási sebessége, $f_{i}$ az i-edik komponensre jellemző forrástag mely a komponenst termelő és fogyasztó reakciók összege. A diffúziós tagban a komponensek diffúziós együttható értékének a vizes oldatokban jellemző $D_{i}=2 \cdot 10^{-9} \mathrm{~m}^{2} / \mathrm{s}$-ot választottam kivéve a hidrogénion esetében, melynek mozgékonysága jellemzően kétszer nagyobb a többi ionhoz képest így $D_{H^{+}}=4 \cdot 10^{-9} \mathrm{~m}^{2} / \mathrm{s}$. Az $\vec{u}$ értékeit a Navier-Stokes-egyenletek megoldásából veszi az algoritmus. A folyamat során, a különböző reakciókban keletkezett és elfogyasztott anyagmennyiséget az utolsó tagban számítjuk. Az irodalmi áttekintésben bemutatásra került, hogy az IAA-rendszer a Dushman és Roebuck reakciókkal jól leírható folyamat. A számításaimban én figyelembe vettem a jodidion és a molekuláris jód közötti egyensúlyi folyamatot, melyben trijodid-ion keletkezik. Az egyensúlyi reakció a következő:

$$
\mathrm{I}_{2}+\mathrm{I}^{-} \rightleftharpoons 3 \mathrm{I}^{-}
$$

Triojodionnal a Dushman és a Roebuck reakciók rendre az alábbi alakra módosulnak:

$$
\begin{gathered}
\mathrm{IO}_{3}^{-}+8 \mathrm{I}^{-}+6 \mathrm{H}^{+} \longrightarrow 3 \mathrm{I}_{3}^{-}+3 \mathrm{H}_{2} \mathrm{O} \\
\mathrm{I}_{3}^{-}+\mathrm{H}_{3} \mathrm{AsO}_{3}+\mathrm{H}_{2} \mathrm{O} \longrightarrow 3 \mathrm{I}^{-}+\mathrm{H}_{2} \mathrm{AsO}_{4}^{-}+3 \mathrm{H}^{+} .
\end{gathered}
$$

A bevezetésben a Dushman reakcióra leírt sebességi egyenlet változatlanul felhasználható, azonban a Roebuck reakció sebességi egyenlete az alábbiak szerint módosul:

$$
r_{2}^{\prime}=\frac{k_{3}^{\prime}\left[\mathrm{I}_{3}\right]\left[\mathrm{H}_{3} \mathrm{AsO}_{3}\right]}{\left[\mathrm{I}^{-}\right]^{2}\left[\mathrm{H}^{+}\right]}
$$

ahol $k_{3}^{\prime}=4,3 \cdot 10^{-5} \mathrm{M}^{2} \mathrm{~s}^{-1}$. 
Ezen adatok felhasználásával az egyes komponensekre a forrástagok az alábbi módon írhatók fel:

$$
\begin{aligned}
& f_{\mathrm{H}^{+}}=-6 \mathrm{r}_{1}+3 \mathrm{r}_{2}^{\prime} \\
& f_{\mathrm{IO}_{3}^{-}}=-\mathrm{r}_{1} \\
& f_{\mathrm{I}^{-}}=-8 \mathrm{r}_{1}+3 \mathrm{r}_{2}^{\prime} \\
& f_{\mathrm{I}_{3}^{-}}=3 \mathrm{r}_{1}-\mathrm{r}_{2}^{\prime} \\
& f_{\mathrm{H}_{3} \mathrm{AsO}_{3}}=-\mathrm{r}_{2}^{\prime} .
\end{aligned}
$$

Az egyenletrendszer megoldásához a CVODE programcsomagot használtam, az OpenFOAM megoldómotorjába integrálva [79]. Az egyenletrendszer merevsége miatt a CVODE csomagba, az ilyen, úgynevezett „stiff” egyenletrendszerek kezelésére beépített implicit BDF (backward diferrentiation) módszert alkalmaztam. A PIMPLE algoritmus iterációs lépéseinek végén a koncentrációmező értékei a (6.25) egyenletrendszerben számolt anyagmennyiségekkel kerülnek korrekcióra. A kezdeti koncentrációértékeket a 6.1 táblázatban tüntettem fel.

6.1. táblázat. A modellszámítások során alkalmazott kezdeti koncentrációértékek a reaktánsés termékoldatrészben.

\begin{tabular}{l|ccccc}
\hline$c_{0} / \mathrm{mmol} \cdot \mathrm{dm}^{-3}$ & $\mathrm{IO}_{3}^{-}$ & $\mathrm{H}_{3} \mathrm{AsO}_{3}$ & $\mathrm{I}_{3}^{-}$ & $\mathrm{I}^{-}$ & $\mathrm{H}^{+}$ \\
\hline reaktáns & 12,90 & 36,12 & 0,0 & $1,29 \cdot 10^{-5}$ & $10^{-4}$ \\
termék & 0,00 & 0,00 & 2,58 & 5,16 & 30,96 \\
\hline
\end{tabular}

Reakció-diffúzió rendszerekben a reakció beindításához autokatalizátornak jelen kell lenni a reaktánsok között. Nincs ez másként az elméleti számításokban sem, az ilyen folyamatok szimulációja során jellemzően a termék oldatrésznek megfelelő összetételú térrész definiálásával történik a reakció iniciálása. A modellszámításokban a platina szál helyzetének megfelelő pozícióban definiáltam termékre jellemző koncentrációval rendelkező cellákat. A program a $z$-tengely mentén minden olyan cellában ezt a kezdeti értéket állította be, amelyek egy 0,5 mm-es sugarú körbe beleestek. Így - a szimmetria peremfeltétel miatt egy félkör alapú egyenes hasábban minden cella termékösszetételnek megfelelő kezdeti koncentrációértéket kaptam. A termékoldatrészben szükség van minimális jodid-ion jelenlétére, különben nem indul be a reakció a (2.5) és a (6.24) egyenleteknek megfelelően. További két komponens eloszlását számíttattam még az algoritmussal de a fentebb leírt módtól eltérően. Az arzénsav mennyiségét az arzénessav kezdeti- és az aktuális koncentrációértéke- 
inek különbségéból nyertem $\left(\left[\mathrm{H}_{3} \mathrm{AsO}_{4}\right]=\left[\mathrm{H}_{3} \mathrm{AsO}_{3}\right]_{0}-\left[\mathrm{H}_{3} \mathrm{AsO}_{3}\right]\right)$, míg a keletkezett jód mennyiségét a (6.21) egyenlet alapján határoztam meg. Ez utóbbihoz az egyensúlyi állandó értékét $K=740 \mathrm{dm}^{3} \mathrm{~mol}^{-1}$-nek vettem R. W. Ramette összefoglaló munkája alapján [80].

Tekintettel arra, hogy a számításokban a Navier-Stokes egyenletek Boussinesq közelítéssel egyszerúsített alakját alkalmaztam, az algoritmus segítségével számítható a reakció során fellépô sûrúségváltozásból - vagyis a Rayleigh-Taylor-instabilitásból - eredő folyadékmozgás nagysága és iránya. Ehhez azonban ismerni kell az folyamat lejátszódása során az aktuális sûrûségértékeket. A folyadék sû́rúsége inkompresszibilis és izotermikus körülmények között annak összetételéből adódik. Ismert összetétel esetén a sưrúség - a koncentráció és sûrúség között lineáris összefüggést feltételezve - az alábbi módon számítható:

$$
\begin{aligned}
\rho_{\mathrm{k}}=\rho_{\mathrm{v}}+\rho_{\mathrm{IO}_{3}^{-}}^{*}\left[\mathrm{IO}_{3}^{-}\right]+\rho_{\mathrm{H}_{3} \mathrm{AsO}_{3}}^{*}\left[\mathrm{H}_{3} \mathrm{AsO}_{3}\right]+\rho_{\mathrm{I}^{-}}^{*}\left[\mathrm{I}^{-}\right]+ \\
\rho_{\mathrm{I}_{3}^{-}}^{*}\left[\mathrm{I}_{3}^{-}\right]+\rho_{\mathrm{H}_{3} \mathrm{AsO}_{4}}^{*}\left[\mathrm{H}_{3} \mathrm{AsO}_{4}\right]=\rho_{\mathrm{v}}+\sum \rho_{\mathrm{i}}^{*} c_{\mathrm{i}},
\end{aligned}
$$

ahol $\rho_{v}$ a víz sûrűsége, $c_{i}$ az adott komponens koncentrációja, $\rho_{i}^{*}$ pedig a sưrüség koncentrációfüggését megadó anyagra jellemző együttható. Az együtthatók értékét a 6.2 táblázat tartalmazza. A modellszámítások során 360 másodpercnyi idôtartamban vizsgáltam 6.2. táblázat. A modellszámítások során alkalmazott, a különböző anyagokra jellemző úgynevezett sứrúség koefficiensek

\begin{tabular}{c|ccccc}
\hline \multicolumn{2}{c}{$\mathrm{IO}_{3}^{-}$} & $\mathrm{H}_{3} \mathrm{AsO}_{3}$ & $\mathrm{I}_{3}^{-}$ & $\mathrm{I}^{-}$ & $\mathrm{H}_{3} \mathrm{AsO}_{4}$ \\
\hline$\rho_{i}^{*} / \mathrm{cm}^{3} \mathrm{~mol}^{-1}$ & 0,1744 & 0,2652 & 0,3086 & 0,1230 & 0,2772 \\
\hline
\end{tabular}

koncentráció- és áramlási viszonyokat, mely 43, illetve 22 másodperccel több annál az idôtartamnál, ami a kísérlet során a rendelkezésünkre állt. Az algoritmus időlépcsőjének $(\Delta t)$ fix $10^{-3} \mathrm{~s}$ értéket választottam. Az eredményeket minden ötezredik időlépcsőben írattam ki, tehát a kiszámított koncentráció-, nyomás- és sebességértékek 5 másodperces felbontásban állnak rendelkezésemre. 


\section{Eredmények}

\subsection{Modulált gravitációs erôtér hatása}

A parabolarepülések során mind zárt, mind nyitott folyadék-gáz határfelület kialakítására alkalmas cellákban végeztünk méréseket. Vizsgáltuk a folyadék-gáz határfelület kialakíthatóságát mikrogravitációban, melynek sikeressége nagyban függ a cellatöltés sebességétôl. Túl gyors töltési sebesség esetén ugyanis - gravitáció hiányában - előfordulhat, hogy a reaktáns oldat nem a cella aljától, a bevezetô nyílások felől tölti ki a reakciócellát, hanem valamilyen nemvárt módon, a cella peremén túljutva akadályozza a teljesen sík folyadék felszín létrehozását. A cellák túlságosan lassú feltöltése esetén, azonban a rakétakísérlet során korlátozottan rendelkezésre álló hasznos kísérleti idő vész kárba. Ebből kifolyólag meg kellett határoznunk egy optimális áramlási sebesség tartományt. Vizsgálnunk kellett a reakció iniciálásának körülményeit is. Révén, hogy az iniciálást platina elektródon történő elektrolízissel végeztük, elkerülhetetlen a gázbuborékok megjelenése az elektród közelében. Ezen buborékok viselkedését, a folyadék-gáz felszínre és az iniciálásra gyakorolt hatását is teszteltük a kísérletek során.

A zárt cellákban elvégzett kísérletekkel, a Marangoni-instabilitás kizárásával, a RayleighTaylor-instabilitás által keltett áramlások és azok frontalakra gyakorolt hatása vizsgálható a modulált gravitációs erôtérben. A parabolarepülések során egyedül a front alakjában, illetve terjedési sebességében bekövetkező változásokat figyeltük. A kialakult folyadékáramlásra is ezek alapján következtettünk. Modulált gravitációs erôtérben az akár függőlegesen, akár vízszintesen iniciált front a cella tetején halad még akkor is, ha az iniciálás mikrogravitációban történik. Amint a repülőgép kilép a mikrogravitációs fázisból a sûrúségkülönbség miatt megindul a keveredés, a termék oldatrész a cella felsô részébe áramlik és az iniciálás helyétôl sugár irányban terjed. A front alakja a már korábbi munkákból ismert ujjas szerkezet, mely a gravitációs erôtér változásának hatására változik. A 7.1. ábrán a zárt celláról három eltérô gravitációs gyorsulási érték mellett készült fotó látható. A normál gravitációs körülmények között jellemző frontalakhoz (7.1 (a)) viszonyítva a hipergravitációs fázisban a front csúcsosabbá válik, görbületi sugara lecsökken (7.1 (b)). A megnövekedett gyorsulási érték miatt a felhajtóerô is $g$-szeresére nő, így az áramlás intenzitása is megnô. Mikor a repülőgép a mikrogravitációs fázisba lép, a $z$ irányú gyorsulási érték mindössze néhány másodperc alatt csökken le a $10^{-2}$-os értékre. A $g$ értékkel a felhajtóerő mértéke is két nagyságrenddel lecsökken. Ebből az következik, hogy a folyadékáramlás kevésbé lesz domináns a rendszerben, így maga a reakció-diffúzió jelensége kerül előtérbe mint hajtóerő. A front alakja a hipergravitációhoz képest ellentétesen változik; a görbületi sugara megnő. Tekintettel arra, hogy a front alakjában jelentős változás csak a csúcs környékén lép fel, ezért a 


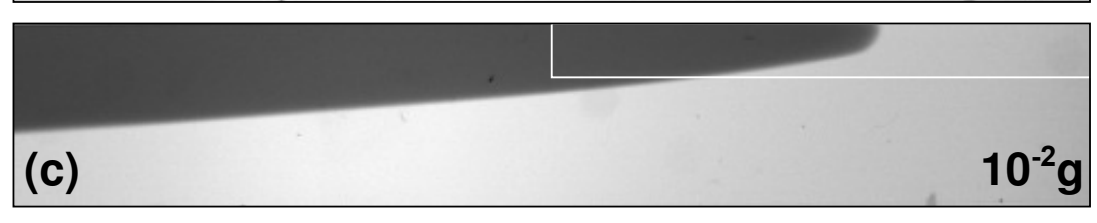

7.1. ábra. A parabolarepülés során a zárt cellában elvégzett kísérleti felvételek normál gyorsulási érték mellett (a), hipergravitációban (b) és mikrogravitációban a kiértékelés során használt területtel (c). A felvételek mindhárom esetben egy $5,8 \mathrm{~cm} \times 1,0 \mathrm{~cm}$-es területet mutatnak.

frontalak részletes vizsgálatát csak a 7.1. ábra (c) képén fehér téglalap által jelölt területen végeztem el. Ennek eredményét a 7.2. ábrán tüntettem fel, mely megmutatja, hogy nem csak a front alakjában történik változás, hanem a frontterjedés sebessége is nagyban megváltozik. Ez természetes, hiszen a reakció-diffúzió által vezérelt front sebessége alacsonyabb, mint ha

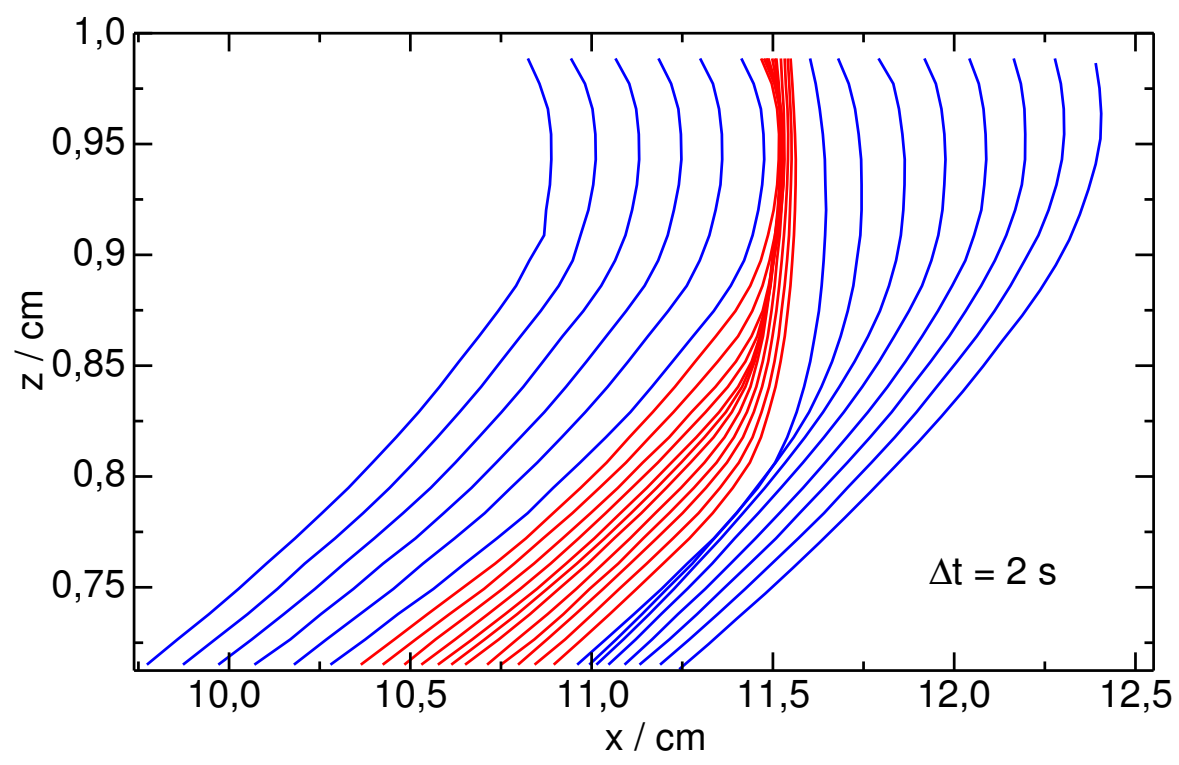

7.2. ábra. A parabolarepülés során zárt cellában terjedő front alakjának és helyzetének 2 szekundumos szuperpozíciója. A kék görbék a hipergravitációban, a piros görbék a mikrogravitációs fázisban rögzített fotókon meghatározott frontalakok.

konvekció is fellép hajtóerőként. Ahogy a front sebessége lecsökken, a csúcs görbületi sugara elkezd növekedni. A görbületekkel tűzdelt frontok kisimulását előidéző jelenséget koráb- 
ban már többen leírták [81]. A jelenség a konkáv görbülettel rendelkező frontot lassítja, míg konvex görbület esetén gyorsító hatása van. Amint a repülőgép elhagyja a mikrogravitációs fázist, a front sebessége ismét megnő és visszanyeri eredeti görbült alakját. A frontsebességének vizsgálatára ábrázoltam a front pozícióját az idő függvényében a 7.3. ábrán. Az így

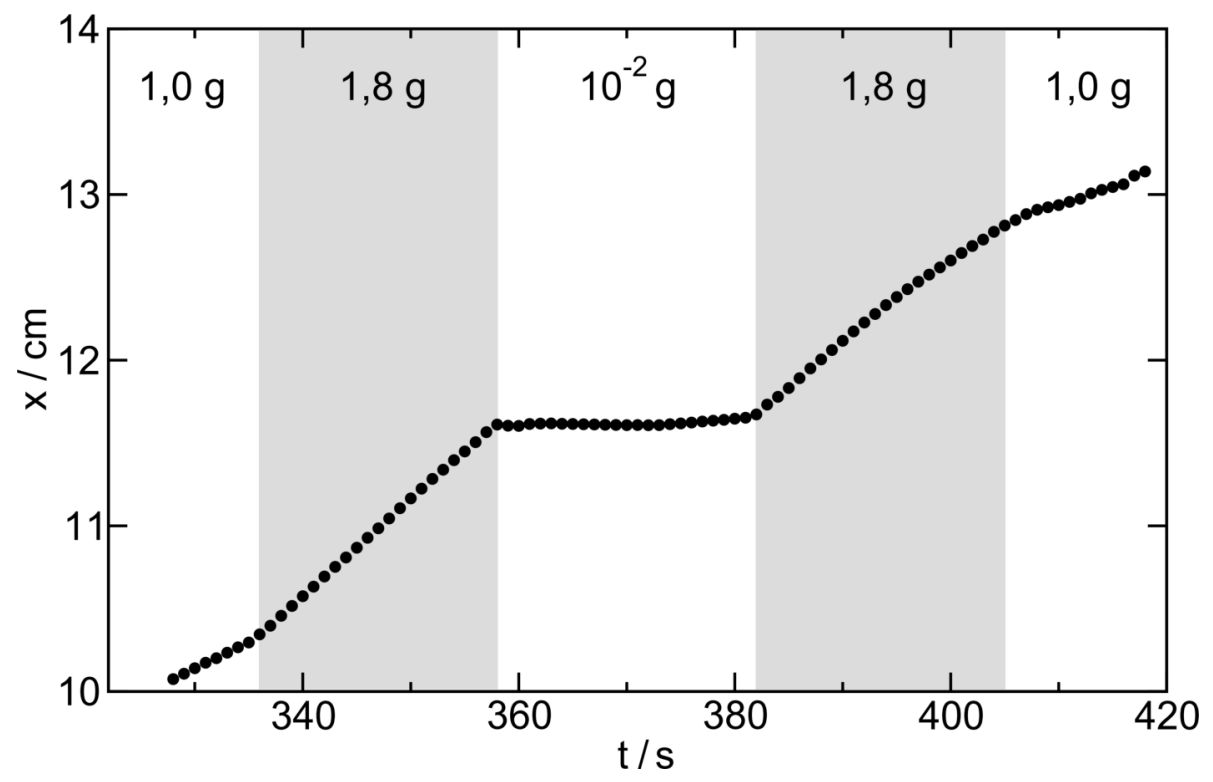

7.3. ábra. A parabolarepülés során zárt cellában terjedô front pozíciója az idő függvényében egy parabola manőver során.

készült ábrán megjelenített adatsor segítségével határoztam meg a frontsebességet úgy, hogy a pontsorozat egyes szakaszaira egyenest illesztettem, mely meredeksége a front terjedési sebességét adja. Ilyen ábrázolásmód esetén amellett, hogy nagyon szemléletesen látszódik, hogy a front sebessége mennyire lecsökken mikrogravitációban, az is szembetúnő, hogy a frontsebessége minimális késedelemmel reagál a gravitációs gyorsulásban bekövetkező változásokra. Zárt cella esetén tehát mind a frontalak, mind pedig a front sebessége változik a gravitációs erôtér változtatásával. A mért frontsebességeket a gravitációs gyorsulás függvényében a 7.4. ábrán tüntettem fel. Megállapítható, hogy csökkenố gravitációs gyorsulás érték mellett a front terjedési sebessége is csökken, de sem a zárt, sem pedig a nyitott rendszer esetén nem áll meg a front teljesen. Ennek oka, hogy a reakció-diffúzió mint hajtóerô nem függ a gravitációs gyorsulás értékétől. Ezek alapján elmondható, hogy nyitott cellában hasonló viselkedést figyeltem meg a front sebességét illetően, mint a zárt cellában elvégzett kísérletek esetén, kivéve mikrogravitációs fázisban. Mikrogravitációban ugyanis nyitott cellában a reakció-diffúzió sebességnél szignifikánsan nagyobb sebességgel haladt a reakciófront. Ez a Marangoni-instabilitás jelenlétére utal. Sikerült tehát a Marangoni-instabilitás hatását kimutatni mikrogravitációban a Rayleigh-Taylor-instabilitás hatásának nagyságrendekkel történő lecsökkentésével . 


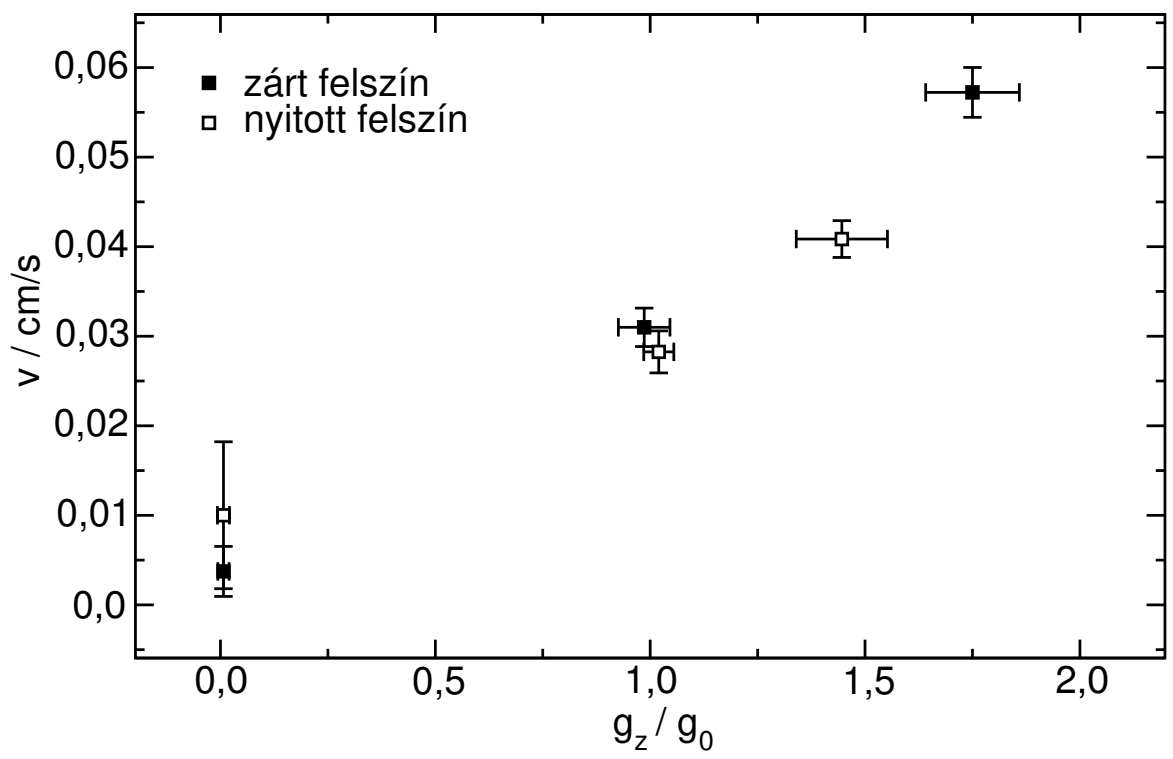

7.4. ábra. Parabolarepülés során kísérletileg meghatározott frontsebességek gyorsulási értéktôl való függése a nyitott $(\square)$, illetve zárt cella (ם) esetén.

\subsection{Földi referenciamérések eredményei}

Annak érdekében, hogy a mikrogravitációban kapott eredményeket, illetve a megfigyelt jelenséget referencia rendszerrel össze tudjam hasonlítani, normál (földi) gravitációs körülmények között is végeztem kísérleteket. Két földi referencia mérést végeztünk el. Az egyik esetben a MASER kísérlet során használt oldatokkal játszattuk le a reakciót és határoztam meg a reakciófront terjedési sebességét abban az esetben, amikor a hajtóerő kizárólag reakció-diffúzió jelensége. Ehhez olyan elrendezést kellett alkalmaznom, amellyel stabil hidrodinamikai sưrúségrétegződés jön létre. Ez függőleges elrendezésben, felülrôl történő iniciálással érhetô el az IAA rendszer esetén. Ez esetben a front felülról lefelé terjed és a kisebb sûrűségú termékoldatész helyezkedik el a nagyobb sưrűségû́ reaktáns oldatrész felett. A mérés során egy $5 \mathrm{~mm}$ átmérőjú, alulról zárt üvegcsövet használtam. Ezt töltöttem meg a reaktáns oldattal, majd egy elektród párra 4 másodperig $5 \mathrm{~V}$ feszültséggel iniciáltam a reakciót. A rögzített képfelvételeket a már korábban ismertetett frontpozíció-idő görbe létrehozásával értékeltem ki. A mérés alapján a tisztán reakció-diffúzió által vezérelt frontterjedés sebessége $1,926 \pm 0,001 \mathrm{~mm} /$ perc-nek adódott.

A jodát-arzénessav rendszerben földi gravitációs körülmények között a reakció során bekövetkezô sûrúségcsökkenés miatt megfelelő orientációban kialakul a Rayleigh - Taylorinstabilitás. Például függőleges frontinicializálás esetén vízszintes sưrúséggradiens alakul ki és konvekciót indukál a folyadékban. A jobb összehasonlíthatóság érdekében megvizsgáltam a rendszer viselkedését a rakétamodulban is. Erre az egyik olyan alkalommal volt lehetőségem, amikor a modul múködésének tesztje, illetve a kísérleti paraméterek finom- 
hangolása történt. Ennek során 10 mm-es cellában a repüléshez meghatározott beállításokkal végeztünk egy próbakísérletet. Mind a Fourier - deflektometria mind pedig a PIV technika kamerájával rögzítettünk felvételeket. A kísérletet végrehajtva, a már korábbi munkákból ismert frontterjedési tulajdonságokat figyeltük meg. Az iniciálás után néhány másodperccel már szabad szemmel is látható módon megjelenik a sötét színú termékoldatrész a katód közvetlen közelében. A keletkező kisebb súrúségú termék oldatrész a felhajtóerô hatására konvekcióval eljut a folyadék-gáz határfelületre. Itt a 7.5. ábrán látható görbült, ujjas alakzat alakul ki, és ezt az alakzatot megtartva terjed a front a bal oldalon elhelyezkedô elektródtól távolodva. Elérve a cella oldalfalát, a front függólegesen lefelé terjed tovább mindaddig,

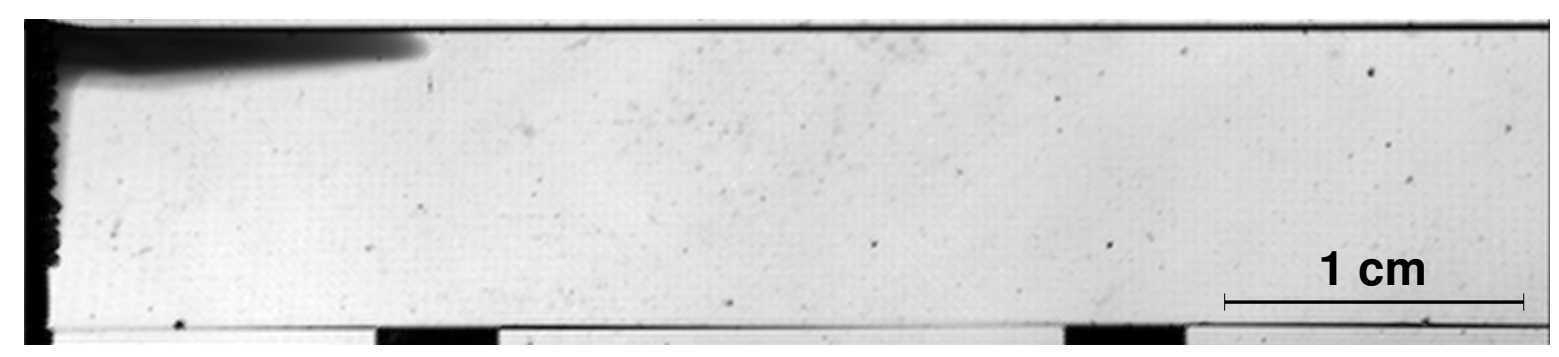

7.5. ábra. Földi referencia mérés során megfigyelt ujjas szerkezetú frontalak az iniciálás után 65,65 másodperceel a 10 mm széles cellában.

amíg rendelkezésre áll reaktáns oldatrész. A front alakjának tér- és időbeli változását a 7.6. ábrán ábrázoltam. Az így nyert adatokból meghatároztam a front terjedési sebességét az $x$-tengely mentén mely $20,6 \pm 0,2 \mathrm{~mm} /$ percnek adódott.

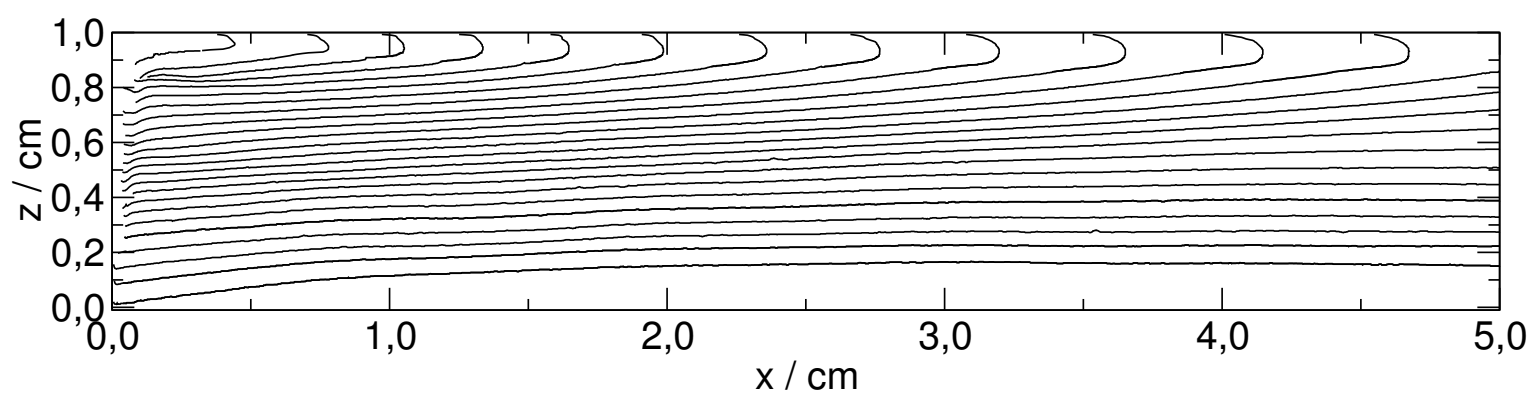

7.6. ábra. Földi referencia mérés során tapasztalt frontalakok 14,9 másodperces szuperpozíciója.

Ez a megnövekedett sebesség a Rayleigh-Taylor-instabilitás által keltett intenzív áramlásból származik. A keletkező kisebb sưrúségú termék oldatrész elmozdulásának hatására a tömbfázisban olyan erők ébrednek, melyek a teljes folyadékréteget mozgásba hozzák. A kialakuló áramlást a PIV felvételek kiértékelésével jelenítettem meg és ábrázoltam a 7.7. ábrán. Ez alapján egy, az óra mutató járásával megegyező irányú konvekciós gyuurú rajzolódik ki. A gyưrú középpontja az ujjas frontalak csúcsa mögött, $x=3,0, z=0,8 \mathrm{~cm}$-nél található. A 
cella alsó felében az áramlás a felszín közelében elmozduló folyadékrésszel nagyságrendileg azonos sebességú, de ellentétes irányú.

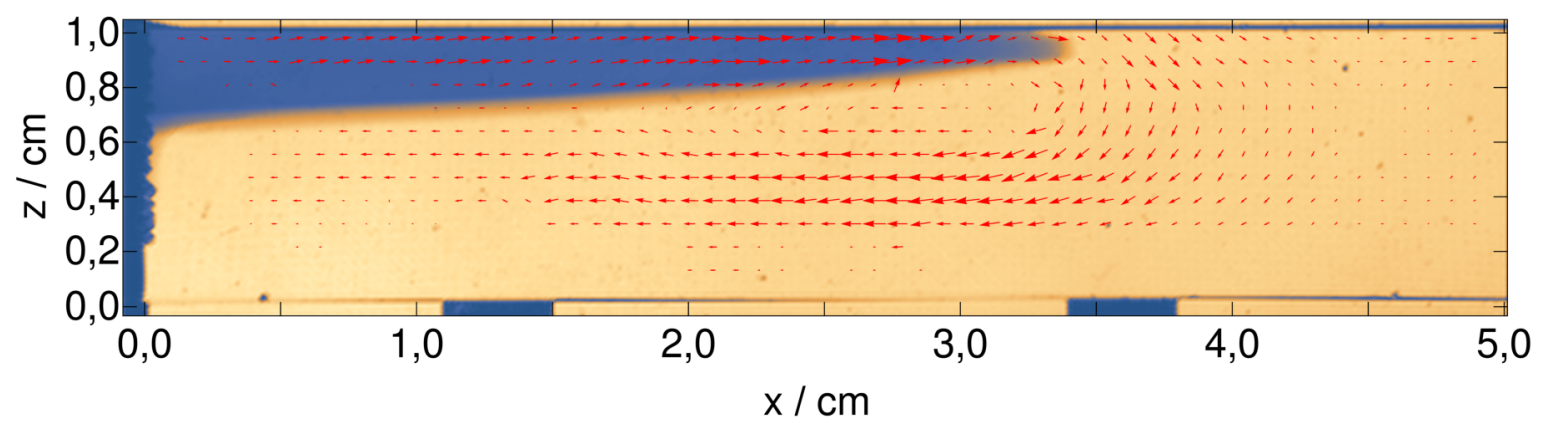

7.7. ábra. A földi referencia mérés során készült PIV felvételek kiértékelésével kapott áramlási kép a $10 \mathrm{~mm}$ széles cellában háttérben az azonos időben készített kísérleti felvétellel, melynek színei nem felelnek meg a valóságban megfigyelhető színeknek. A kiértékelés során a felhasznált két PIV kép közötti időkülönbség 1,25 másodperc. 


\subsection{Mikrogravitációban elvégzett mérések eredményei}

Mikrogravitációban, a Rayleigh-Taylor-instabilitás hiányában gyengébb áramlások kialakulására számíthatunk. A felhajtóerő megszúnésével az a hatás kerül kiküszöbölésre, amely a korábbi kísérletekben nagy mértékben elnyomta a felületi feszültség különbségéből eredô erô hatását. Ez által a frontalak elnyújtottságának csökkenése is várható. A MASER-13 rakéta fedélzetén előállított közel 6 percnyi tisztán mikrogravitációs állapot megfelelő körülménynek bizonyult a Marangoni-instabilitás hatásának vizsgálatára.

A MASER rakéta fedélzetén két cellában végeztünk kísérleteket, melyek minden egyes lépését, úgy mint a cellák feltöltését, illetve a reakció iniciálását is a mikrogravitációs fázisban hajtottuk végre. Az automatikus feltöltés után manuálisan állítottuk be a folyadékszintet a cellákban és mind az automatizált fázis, mind pedig a kézi töltés tökéletesen múködött. A cellák feltöltése során nem történt semmilyen váratlan esemény, a folyadék a cellát a bevezetések felől töltötte ki és a folyadékréteget a felületi feszültség egyben tartotta. A választott töltési sebesség tehát megfelelőnek bizonyult mindkét cella esetében. A reakció iniciálásában sem következett be nem várt esemény, a választott feszültség érték és idôtartam elegendő volt a reakció elindításához. A feszültség elektródokra kapcsolása után megjelentek a gázbuborékok azok felszínén, és csupán egy buborék szakadt el az elektród felületérôl, de az sem érte el a folyadék-gáz határfelületet, mindössze néhány millimétert mozdult el az elektród mentén.

A buborékok megjelenése után néhány másodperccel a sötét színú termékoldatrész is feltűnik az elektród közvetlen környezetében, viszont felhajtóerő hiányában a front megőrzi az iniciálás geometriájával megegyező alakot. A front iniciálása az elektród felső 8 mm-es szakaszán történt meg a $10 \mathrm{~mm}$ széles cellában, így a front alsó részén egy görbült geometria a jellemző (lásd a 7.8. ábrát). A görbült rész sugara a front terjedése során a végtelenbe tart,

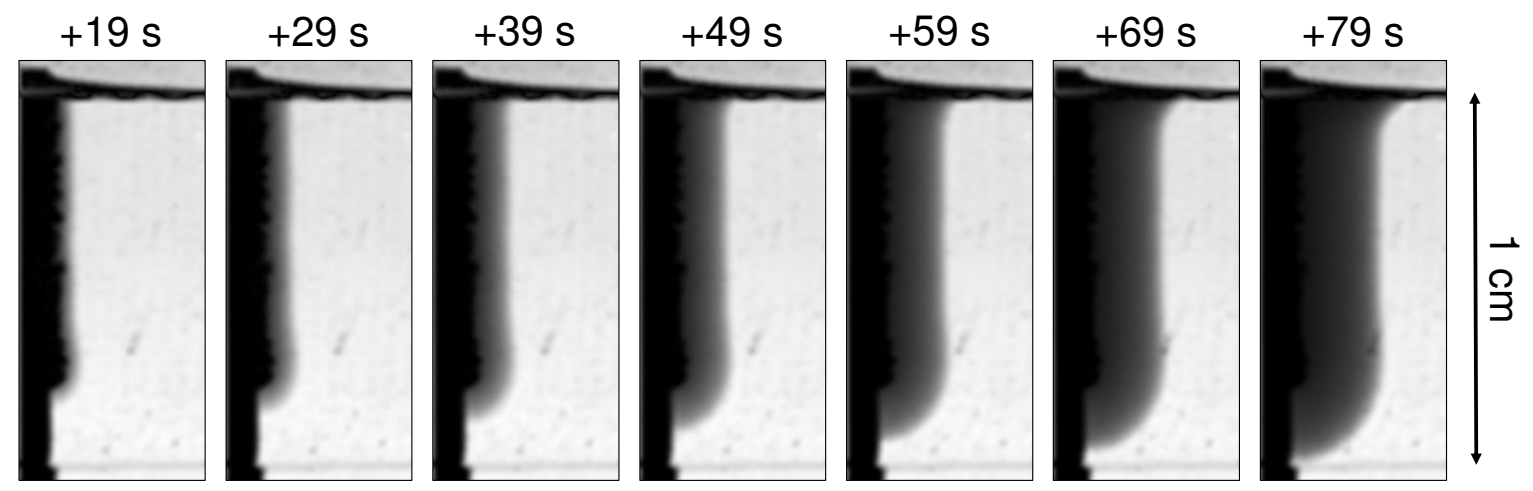

7.8. ábra. A kezdeti frontalak változása az elektród közvetlen környezetében az iniciálást követő 79 másodpercben.

így a front alsó részének görbültsége egy adott idő után eltûnik. A front alakjában bekövet- 
kező változás a folyadék-gáz határfelület közelében éppen ellentétes. A front ezen szakasza az iniciálást követő 39. másodpercig még az elektróddal párhuzamos, egyenes irányultságú. A 7.8. ábrán az iniciálást követô 49. másodpercben a front legfelsô rövid szakaszán már látszódik, későbbi képeken pedig egyre jobban kivehető, hogy egy görbület alakul ki. A folyadék-gáz határfelületen tehát egy torzító hatás megjelenését tapasztaltam. A korábban már bemutatott front pozíció-alak görbesorozatot a MASER kísérlet felvételei alapján is elkészítettem és a 7.9. ábrán mutatom be. A 7.9. ábrán a frontalak tér- és időbeli változását

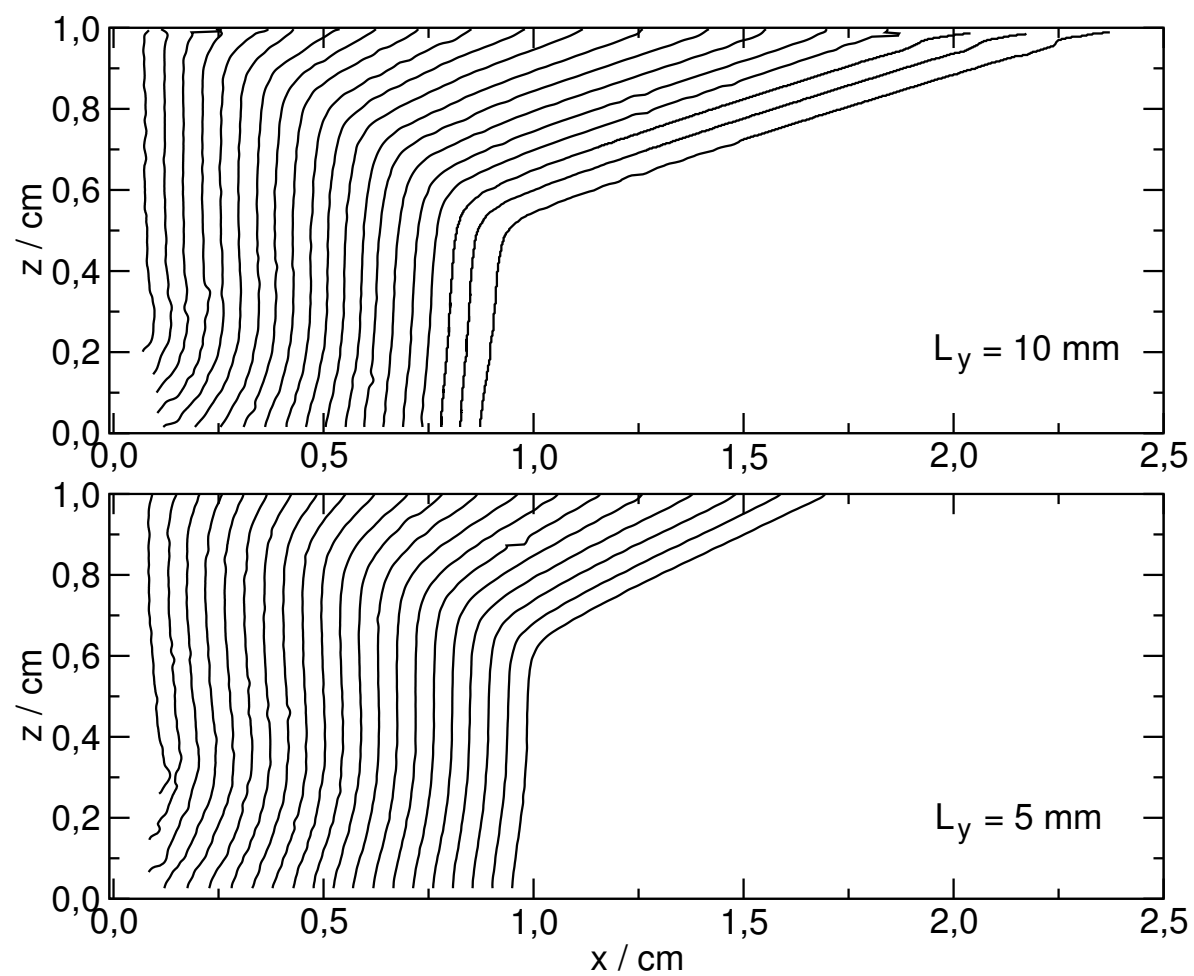

7.9. ábra. A reakciófront alakjának tér-és idôbeli fejlődése mikrogravitációban a 10 és $5 \mathrm{~mm}$ széles cellában. Két szomszédos frontalak közötti idókülönbség 14,85 másodperc.

követhetjük a rakétakísérlet teljes idôtartama alatt. Látható, hogy reakciófront viselkedése mind a cella alján eltûnő, mind pedig a folyadék-gáz határfelület közelében megjelenő dôlt részt illetôen az eltérő cellákban nagy hasonlóságot mutat. A keskenyebb (5 mm széles) cellában a front terjedésére 337 másodperc, míg a 10 mm széles cellában a hosszabb töltési periódus miatt 317 másodperc idô állt rendelkezésre mikrogravitációban. A cella alsó részében a front által megtett távolság az eltelt idővel arányos, azonban a folyadék-gáz határfelületen az $5 \mathrm{~mm}$ széles cellában a front kisebb távolságot tesz meg annak ellenére, hogy több idố állt rendelkezésére. Az is szembetűnô, hogy ellentétben a földi-, illetve a modulált gravitációs körülmények között elvégzett kísérletekkel, a frontterjedés a cella teljes keresztmetszetében jellemző, nem korlátozódik a cella felsố negyedére. Hosszabb időtartamon vizsgálva a front alakját az látható, hogy a front felsố része a görbület megjelenése után megdôl és a 
cella felső részében meg is ôrzi ezt a dőlt irányultságot a kísérlet teljes hátralévő részében. Gyakorlatilag a front két egyenes szakaszra bontható: a dôlt felső szakaszra, illetve az alsó $z$-tengellyel párhuzamos szakaszra. Bár a reakciófront az idô előrehaladtával egy állandósult konkáv alakzat, a folyadék gáz határfelülettel érintkezô végére a dolgozat további részében úgy fogok hivatkozni, mint a front „csúcsa”. A front terjedési sebességét három különbözô vonal mentén határoztam meg. A három szakaszból kettő az $x$-tengellyel párhuzamos. Ezek esetében egy-egy 966 képpont $\times 24$ képpontos területen vett időbeli átlagos frontpozíció adatokat gyưjtöttem ki és ábrázoltam az idő függvényében. Az egyik ilyen területet a folyadék-gáz határfelülethez közel jelöltem ki úgy, hogy a középvonala $z=9,23 \mathrm{~mm}$-es koordinátánál legyen, míg a másik terület középvonala a cella aljánál $z=0,55 \mathrm{~mm}$-es koordinátához került. De nem csak az $x$-tengellyel párhuzamos terjedési sebességet határoztam meg, hanem a dőlt résznek a tömbfázis felé, a frontalakra merôleges úgynevezett normál irányba történő terjedésének a sebességét is. Ezt úgy hajtottam végre, hogy a dőlt szakaszokra illesztett egyenesek egyenleteinek segítségével kiszámoltam a szomszédos szakaszok közötti távolságot és azt ábrázoltam az idő függvényében a 7.10. ábrán. Az ábrán jól látható, hogy a görbék meredekségében - fôként a folyadék-gáz határfelület közelében - egy 150 - 175 másodperc hosszúságú tranziens állapot jellemzô. Ez idô alatt a front folyamatosan gyorsul, majd a sebessége a kísérlet későbbi időtartamában állandónak tekinthetô sebességet vesz fel. A cella alján mért frontsebességekben szignifikáns változás nem mérhetô, és az egyenesek meredekségén látható, hogy az itt mért frontsebesség értékek megegyeznek a két eltérő méretû cellában. Ezzel szemben a cellák felsố részében mért frontsebességekben már szignifikáns eltérés mutatkozik a két különböző cellában. A front dôlt részének tömbfázis felé történô terjedési sebesség sem függ a cellamérettől. Ráadásul ezen egyenesek meredeksége nagy hasonlóságot mutat a cellák alsó részén a $z$-tengellyel párhuzamos irányultságú frontszakasz terjedését leíró pontsorozat meredekségével.

A 7.10. ábrán szereplő pontsorozatok $x=200$ és $x=260$ másodperc közötti szakaszaira illesztett egyenesek meredekségei alapján meghatározott, illetve a földi referencia mérések során kapott sebességeket mm/perc mértékegységre történő átváltás után a 7.1. táblázatban gyújtöttem össze. A kapott frontsebességek alapján látható, hogy a folyadék-gáz határfelü-

\begin{tabular}{|l||c|c|c|}
\hline $\mathrm{v}(\mathrm{mm} /$ perc $)$ & felszínhez közel & a cella alján & ferde rész normál irányban \\
\hline \hline $5 \mathrm{~mm}(0 \mathrm{~g})$ & $4,16 \pm 0,02$ & $1,848 \pm 0,003$ & $2,058 \pm 0,009$ \\
$10 \mathrm{~mm}(0 \mathrm{~g})$ & $5,72 \pm 0,01$ & $1,813 \pm 0,003$ & $1,95 \pm 0,01$ \\
\hline $10 \mathrm{~mm}(1 \mathrm{~g})$ & $20,61 \pm 0,2$ & - \\
\hline \multicolumn{2}{|c|}{ Tisztán reakció-diffúzió vezérelt front esetén: $1,926 \pm 0,001$} \\
\hline \multicolumn{2}{|c|}{ 7.1. táblázat. Kísérletileg meghatározott frontsebesség értékek }
\end{tabular}

leten a megnövekedett frontterjedési sebesség okozza a front felső szakaszának megdőlését, míg a tömbfázisban csak minimális eltérés mutatkozik a reakció-diffúzió által vezérelt front 


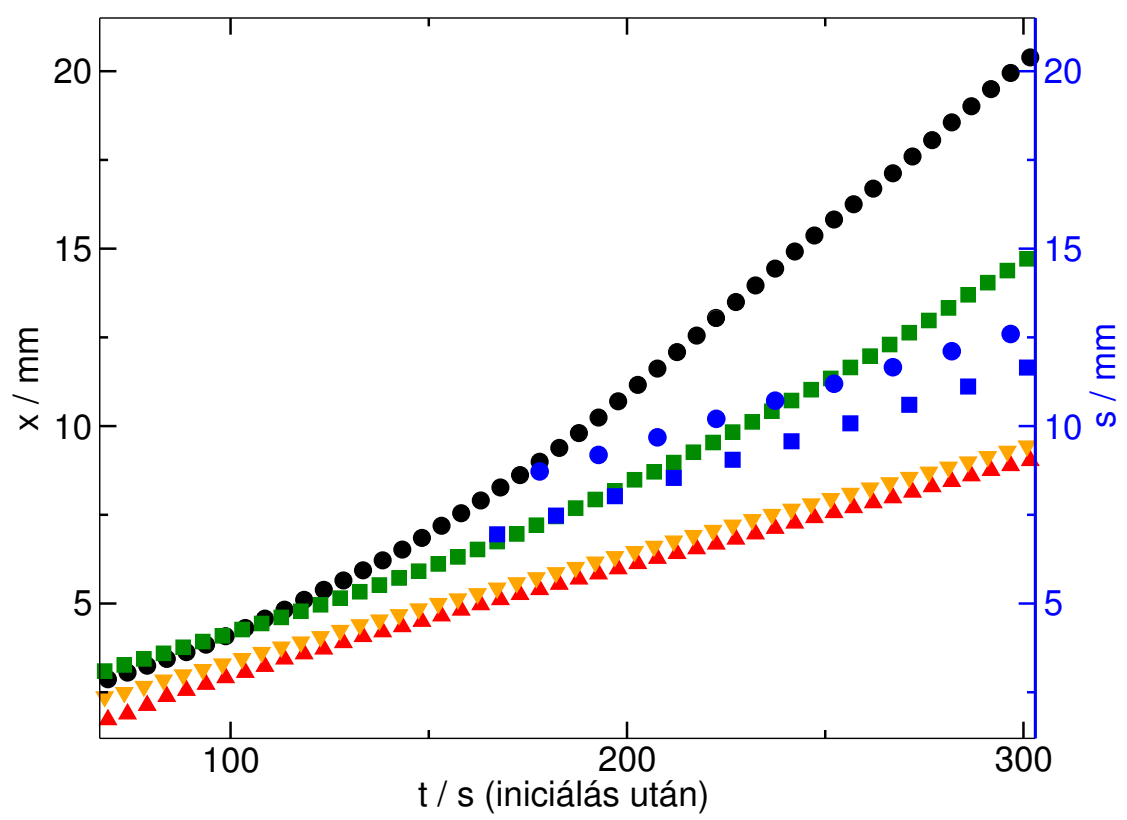

7.10. ábra. A front különböző szakaszainak pozíciója az idő függvényében a két rekaciócellában (a folyadék-gáz határfelület közelében a 10 mm-es cellában (•), az 5 mm-es cellában ( $\bullet$ ), a cella alsó részében a 10 mm-es cellában $(\triangle)$, az 5 mm-es cellában ( $\vee$ ), illetve a dôlt rész normál irányú terjedése során a 10 mm-es cellában (•) és az 5 mm-es cellában (๘).

terjedési sebességéhez képest.

A frontsebesség adatok alapján megalkottunk egy egyszerú modellt, amellyel a front terjedését geometriai terjedéssel közelítettük. Ennek a modellnek a lényege, hogy azt feltételezzük, hogy a front mindenhol reakció-diffúzió által vezérelt front esetén megfigyelhetô sebességgel $\left(V_{0}\right)$ terjed. A frontot különböző pontforrásokból indított $V_{0}$ sebességgel terjedő hullámok burkológörbéje rajzolja ki. Ezen feltételeket úgy állítjuk elő, hogy a platina szálnak megfelelő pozícióban álló pontforrásokat, míg a folyadék-gáz határfelületen egy mozgó pontforrást definiálunk. Ezen forrásokból állandó sebességú hullámokat indítunk és egy adott $\Delta \mathrm{t}$ idő eltelte után a hullámok burkológörbéje rajzolja ki a $t_{0}+\Delta \mathrm{t}$ időpontban jellemző frontalakot. A modell segítségével jó közelítéssel rekonstruálni tudtuk a kialakuló egyszerú frontalakot a kísérlet stacionárius idôszakára. A módszerrel két dimenzióban rekonstruált frontalakokat a 7.11. ábrán tüntettem fel szaggatott vonallal.

A modell matematikailag az alábbi módon írható le. Azt kell keresnünk, hogy a tér egy adott $(x, z)$ koordinátákkal rendelkező pontját melyik típusú hullám éri el előbb: a cella alsó részén reakció-diffúzió frontra jellemző $\left(V_{0}\right)$ sebességgel terjedő, vagy a felszínen a Marangoni-instabilitásból eredő $\left(V_{m}\right)$ sebességú áramlás értékével megnövelt sebességgel mozgó pontból induló. A szükséges időt az előbbi esetben a (7.1) utóbbi esetben pedig 


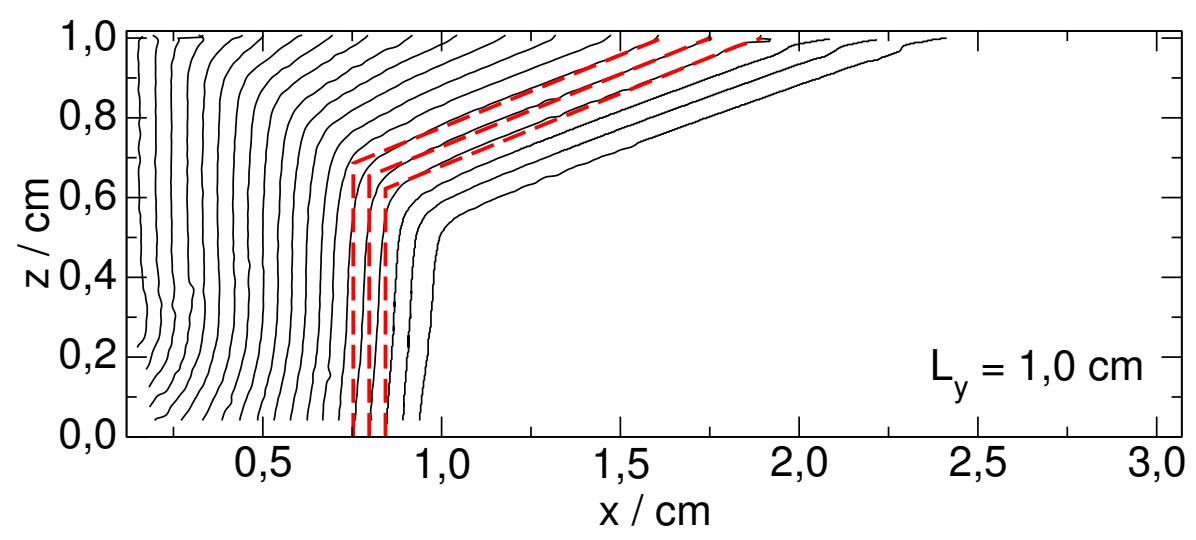

7.11. ábra. Kísérleti frontalakok közelítése geometriai frontterjedéssel a $10 \mathrm{~mm}$ széles cellákban. A kísérleti frontalak fekete vonallal, míg a geometriai frontterjedés eredményeként kapott frontalak piros szaggatott vonallal van jelölve. Két szomszédos frontalak közötti időkülönbség 14,85 másodperc.

a (7.2) egyenletek írják le:

$$
\begin{gathered}
\frac{\sqrt{x^{2}+(s-z)^{2}}}{V_{0}} \\
\frac{s-l}{V_{m}}+\frac{\sqrt{(s-l-x)^{2}+(l-z)^{2}}}{V_{0}} .
\end{gathered}
$$

A (7.2) egyenlet estén látható, hogy a mozgás két részből írható fel: egy $V_{m}$ sebességú felszínen történő elmozdulásból $s-l$ távolságon és majd onnan egy $V_{0}$ sebességú elmozdulás a második tag számlálójának megfelelô távolságon. Az egyenletekben az $x$ és $z$ értékek a vizsgált pont koordinátái, $s$ az elsô egyenletben a pontforrás $z$ szerinti, a második egyenletben pedig $x$ szerinti koordinátája, $l$ pedig a reakciócella magassága. A (7.1) egyenlet esetén az út megtételéhez szükséges idô akkor minimális, ha $s=z$-vel és így $t_{\min }=x V_{0}^{-1}$.

A (7.2) egyenlet esetén nem egyértelmú, ezért a (7.2) egyenlet út szerinti deriváltját kell előállítanunk és keresnünk a minimumát:

$$
\frac{d t}{d s}=\frac{1}{V_{m}}+\frac{2(s-l-x)}{2 V_{0} \sqrt{(s-l-x)^{2}+(l-z)^{2}}} .
$$

A (7.3) egyenlet átrendezésével az alábbi alakot kapjuk:

$$
t_{\text {min }}=\frac{x}{V_{m}}+\frac{l-z}{V_{m}}\left(\frac{V_{0}^{2}}{V_{m}^{2}-V_{0}^{2}}+\frac{V_{m}}{V_{0}} \sqrt{\frac{V_{0}^{2}}{V_{m}^{2}-V_{0}^{2}}+1}\right) .
$$

A számításokat a Wolfram Mathematica programcsomagban végeztem el. A programkód a disszertáció mellékletében megtalálható.

A Marangoni-instabilitás által keltett folyadékáramlás részletes leírását a PIV technikával rögzített fotók kiértékelésével szerettem volna elvégezni. A PIV fotók keresztkorrelá- 
ciós módszerrel történő kiértékelése során csak nagy nehézségek árán sikerült megtalálni azokat a paramétereket, amelyeknél a cella teljes területén realisztikus áramlási képet adó vektormezôt kapunk. Ennek lehetséges okait már a 5. fejezetben bemutattam. Azonban 32 képpont $\times 32$ képpont élhosszúságú részterületek választásával 24,5 - 26,6 szekundumos időkülönbségnél már reális áramlási kép rajzolódik ki mindkét cella esetén. Az eredményként kapott vektormezőt mindkét esetben azon a deflektometriás kísérleti fotón helyeztem el, amely időben a két felhasznált PIV fotó közötti középidőhöz tartozik. Az ilyen módon kapott áramképek a 7.12. ábrán láthatók. A frontalakot ábrázoló fotó színei nem felelnek meg a valóságnak, a termék oldatrész ugyanis sárga színú a trijodidion tartalma miatt, míg a fekete-fehér kísérleti felvételen ugyanez a terület sötét árnyalattal jelenik meg.

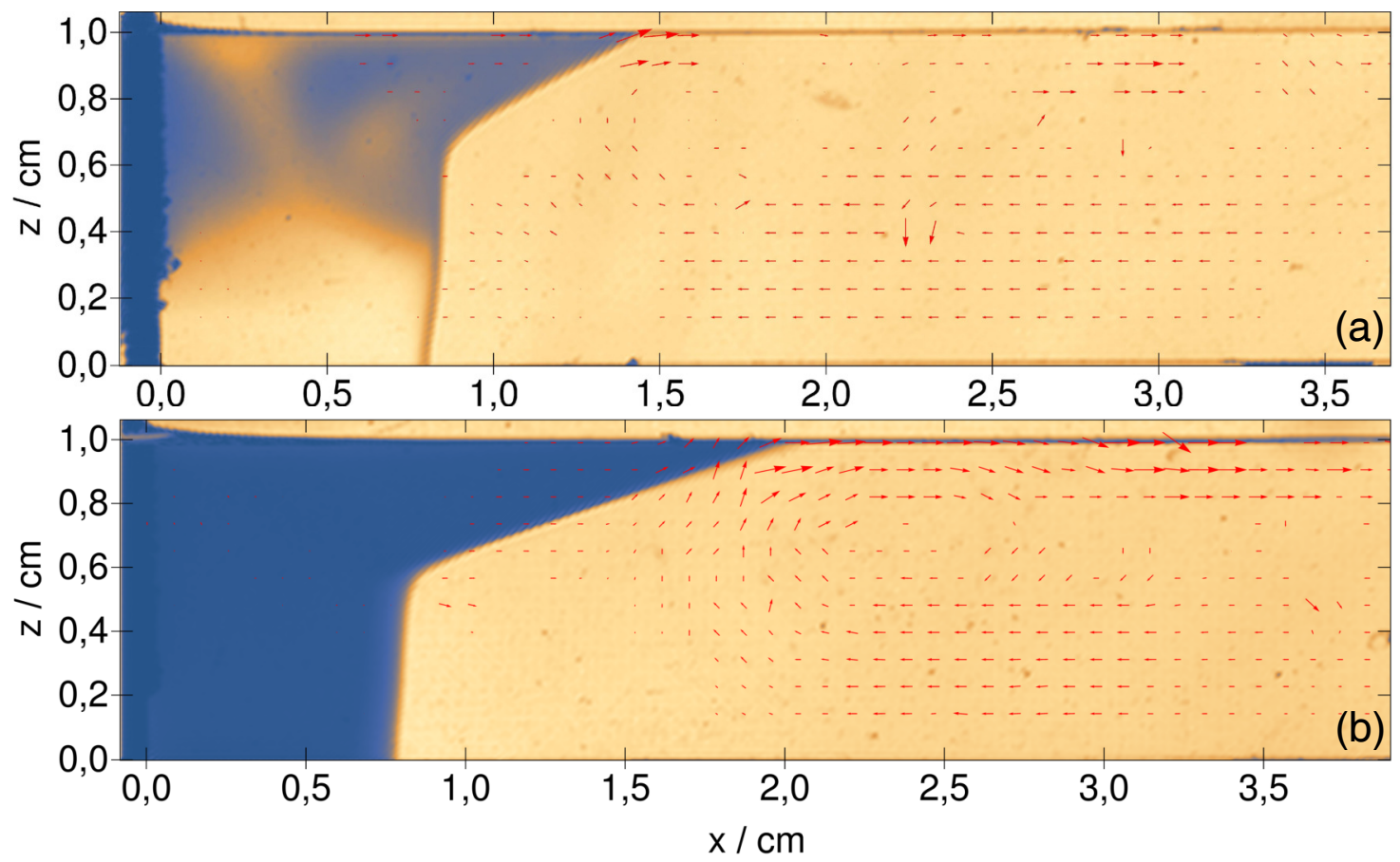

7.12. ábra. A PIV kiértékelés eredményeként kapott vektormezők az 5, illetve 10 mm széles cellában. A vektormezők 24,5 és 26,6 másodperc alatt történő elmozdulást mutatják rendre az $5 \mathrm{~mm}$ széles és $10 \mathrm{~mm}$ széles cellában. A kísérleti felvétel színei nem felelnek meg a valóságban megfigyelt színeknek és az elmozdulás időtartamának középidejéhez tartózó idôben készült.

A két eltérő méretû cellában hasonló áramkép kialakulását mutatja a 7.12. ábra. A legnagyobb sebességek jellemzően ott jelennek meg, ahol a front a folyadék-gáz határfelülettel találkozik. A cella felső harmadában a határfelület közelében növekvő $x$ irányban történik az áramlás, míg a cella alsó kétharmadában ellentétes irányú visszaáramlás a jellemző. A kirajzolódó konvekciós gyưrû az óramutató járásával megegyezô irányú, középpontja a front csúcsa előtt helyezkedik el a felszíntôl számított mintegy 2,5-3 mm-es mélységben. Az 5 mm széles cellában kapott PIV eredmény kevésbé látványos, azonban a fôbb áramlási 
jellemzők leolvashatók. A hiányzó sebességértékeket a kisebb intenzitású áramlás, illetve a kevesebb részecske jelenléte okozhatta. A kapott eredmény zajosságát a megvilágított síkból kilépő, és a síkban újonnan megjelenő részecskék okozzák. A 10 mm-es cellában a PIV mérés eredménye jónak mondható mivel kevés zajt, illetve hiányos területet tartalmaz. A 10 mm szélességú cellában nagyobb gradiensek jelenlétére utaló nyom nem látható az. A határfelülettől a $z$-tengely mentén távolodva homogén sebességeloszlás adódott a konvekciós gyưrú középpontja felé. A cella alsó lapjának irányában a folyadékáram ellentétes irányú, kisebb intenzitású és itt sem jellemző nagy sebességgradiens.

A homogén sebességeloszlás ténye már a kiértékelés korai szakaszában ellentmondást mutatott a megfigyeléseimmel. A PIV felvételekből készített gyorsított videó felvételeken ugyanis látszódott, hogy a határfelülethez közelebb elhelyezkedő részecskék jóval nagyobb elmozdulást szenvednek a kísérlet lejátszódása során, mint az akár 1-2 mm-rel mélyebben elhelyezkedô társaik. Ez jelentôs sebességgradiens jelenlétére utal. A folyadékáramlás pontosabb leírásához egyébként is szükség volt egy nagyobb felbontással rendelkezô módszerrel történő kiértékelésre, de a felmerült ellentmondás még inkább szükségessé tette ezt. Ennél fogva részecske szintû kiértékelést is végeztem a cellákban. Ezt az úgynevezett részecskekövetésen alapuló sebességmeghatározás (PTV) módszerrel végeztem. A módszer segítségével a részecskék egyéni mozgása írható le nagy részletességgel két dimenzióban, így a részecskék $x$ - és $z$-koordinátái mellett megkapjuk azok mindenkori sebességét is. A $10 \mathrm{~mm}$-es cellában a 7.13. ábrán sárga téglalap által határolt részterületen található részecskéken végeztem a kiértékelést. A terület kiválasztásánál elsődleges szempont volt, hogy elegendő részecs-

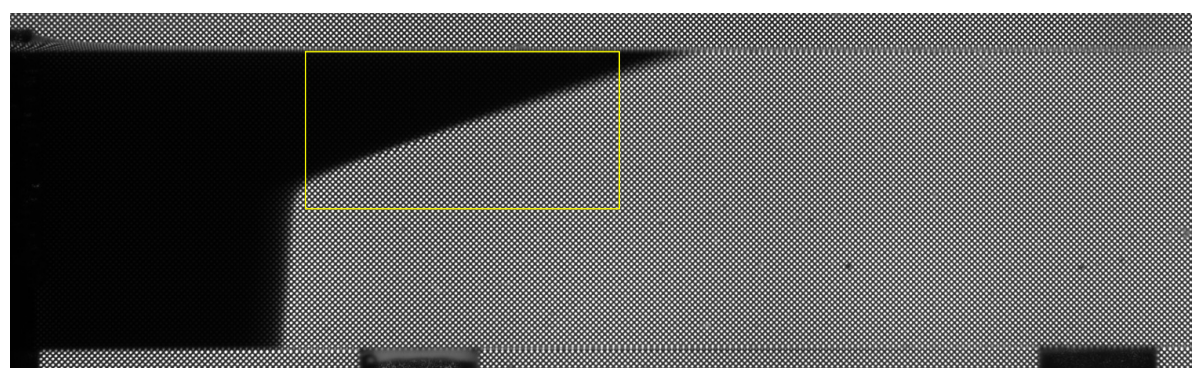

7.13. ábra. A PTV mérésekhez felhasznált részecskék mintázási területének helye (sárga téglalappal jelölve) a $10 \mathrm{~mm}$ széles cellában.

ke álljon rendelkezésre, amelyek mozgása a teljes kísérlet során követhetô, illetve hogy a területen a front teljesen áthaladjon, ugyanakkor a front már ne a tranziens állapotában legyen. Az egyik ilyen mérés eredményét mutatja a 7.14. ábra. A területen kiválasztott 10 mérésre alkalmas részecske elmozdulását láthatjuk az idő függvényében, és az elmozdulás első deriváltját, mely a részecske sebességét adja. Látható, hogy a felszíntôl távolodva a részecskék elmozdulása szignifikánsan csökken. Az elsô 1 mm-en belül az elmozdulás az 0,1 mm-nél követett részecske elmozdulásának a fele, 2 mm-es mélységben elhelyezkedő 
részecskék pedig már harmad akkora elmozdulást mutatnak. Nagyságrendi különbség pedig már 2,5 mm mélységben jelentkezik. A részecskék sebességében ugyanez a trend figyelhetô meg, ha a maximális sebesség értékek alakulását vesszük figyelembe. A részecskék sebességprofilja független a mélységüktôl és nagy asszimmetriát mutat. A részecskék a kísérlet 50. másodpercétôl jönnek mozgásba, ahonnan sebességük folyamatosan növekszik. A maximális sebesség elérése után nagymértékú lassulás következik, melynek mértéke csökken, amíg a részecske meg nem áll. A PTV mérés során vettem észre, hogy a részecskék xz-síkban jellemző mozgása mellett egyfajta „rezgő” mozgást is végeznek, de azt kizárólag az $x$-tengely mentén. A rezgés frekvenciája méréseink alapján 2,0 Hz-nek adódott, amely - mint az Európai Úrügynökséggel tett egyeztetés alapján kiderült - egy másik, a rakétán elhelyezett biológiai kísérletnek helyt adó modulba beépített centrifuga nem megfelelő balanszírozásából származott. Ez a forrása annak a zajnak, ami a 7.14. ábrán látható mind az elmozdulás-idő, mind a sebesség-idő görbéken.

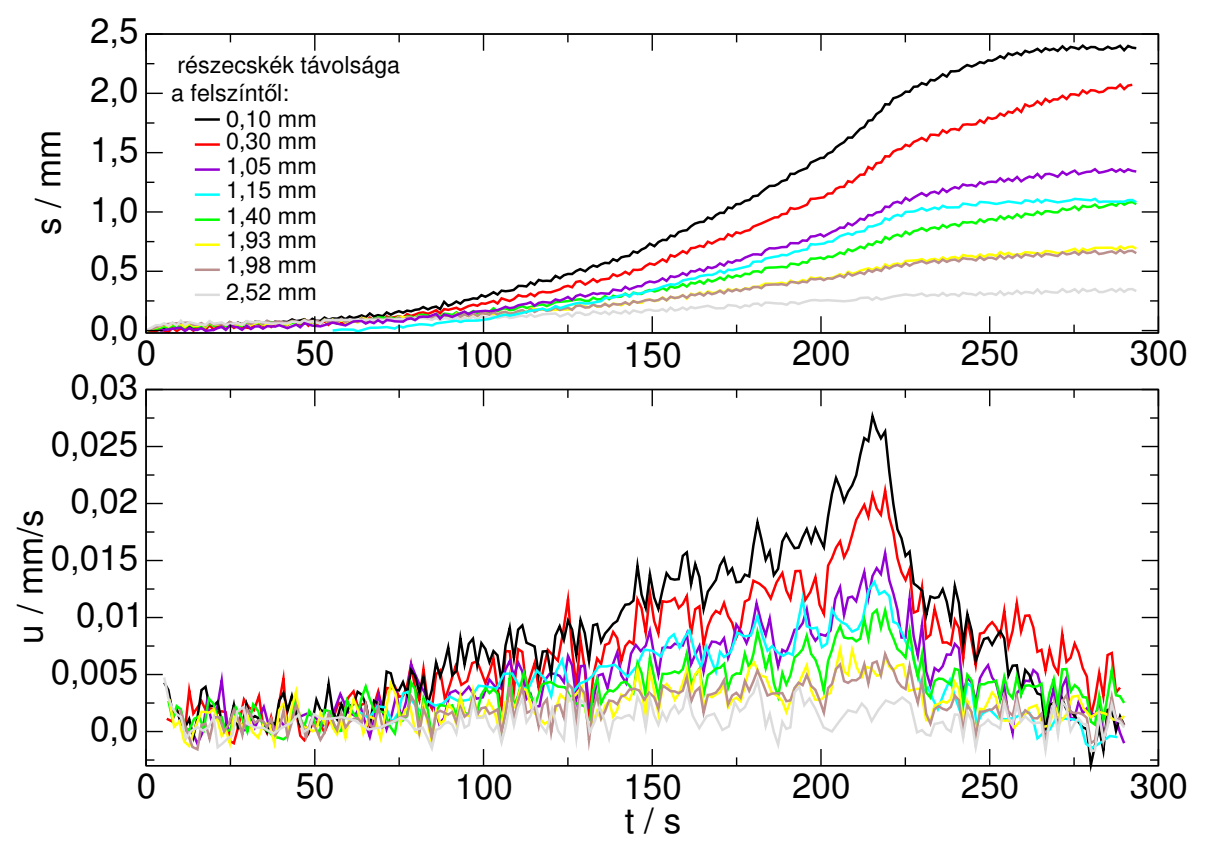

7.14. ábra. A 10 mm széles cellában elvégzett PTV mérés eredményeként kapott elmozdulásidő görbék (felül) és azok deriváltja (alul). A görbék különböző mélységekben elhelyezkedő részecskék elmozdulását mutatják a kísérlet teljes időtartama alatt.

A folyadék-gáz határfelület közelében kialakuló sebességeloszlás részletes leírásához vizsgáltam a $10 \mathrm{~mm}$-es cella felső felében található részecskék sebességének mélységtől való függését. A feljebb bemutatott területen található 18 részecske maximális sebessége és részecskék felszíntốl számított mélysége közötti összefüggést mutatja be a 7.15. ábra. Ezen látható, hogy a felszíntôl számított 3 mm-en belül egy nagyságrenddel csökken a részecskék maximális sebessége, továbbá jól kirajzolódik az aszimmetrikus konvekciós gyứú, melynek a középpontja $\mathrm{z} \approx 7 \mathrm{~mm}$-nél van, amely alatt a részecskék jellemző elmozdulási iránya 


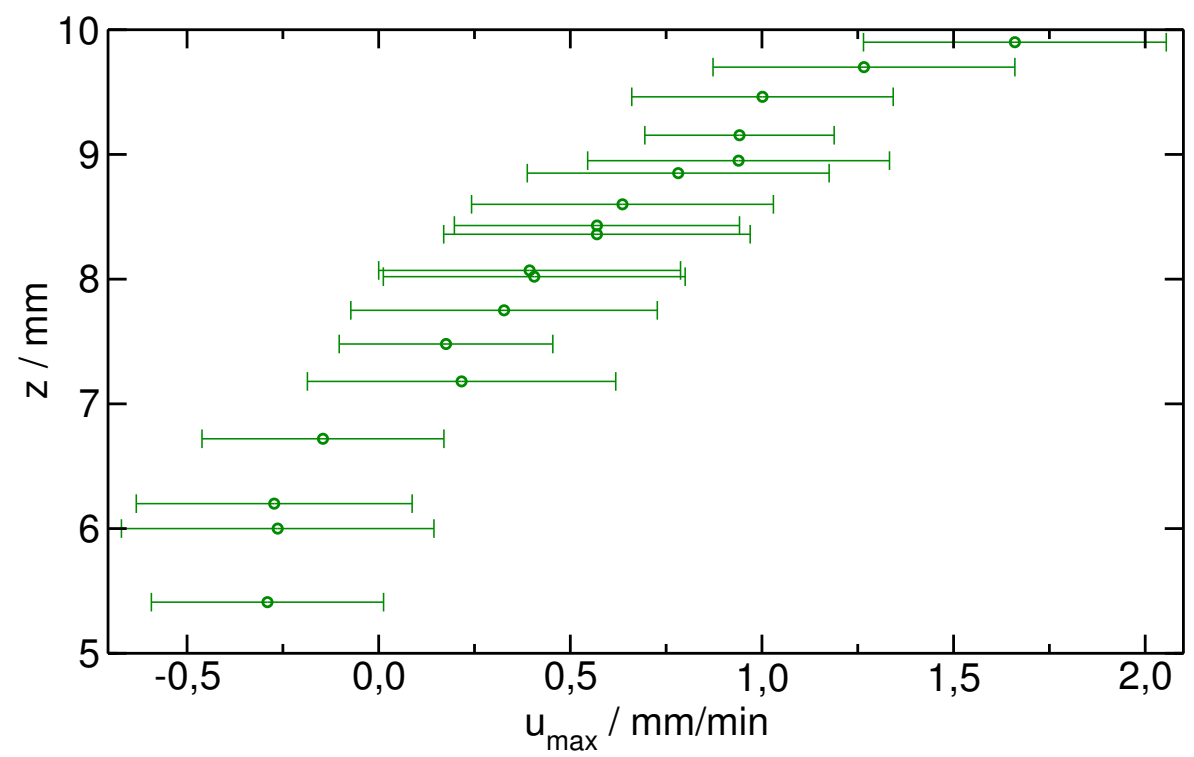

7.15. ábra. 18 különböző mélységben elhelyezkedő PIV részecske maximális $x$-tengely menti sebessége.

megváltozik.

A részecskék $x$-tengely menti mozgásának jellemzése után megvizsgáltam azok két dimenzióban, a lézer által megvilágított lap mentén végzett mozgásukat is. Révén, hogy a PTV technika a részecskék folyamatos követését teszi lehetôvé ezáltal a részecskék által bejárt pályát is megkaphatjuk az $x z$-síkban, így azok mozgása nagyobb részletességgel vizsgálható. A 7.13. ábrán jelölt területen kiválasztott részecskék által, a kísérlet teljes idôtartama alatt bejárt utat mutatja a 7.16. ábra. Látható, hogy a konvekciós gyưrü középpontja felett elhelyezkedő részecskék elmozdulásában jóval nagyobb különbségek mutatkoznak. A felszínhez közeli részecskék elmozdulásában nem látszik nagyobb $z$ irányú komponens, azonban a felszíntől távolodva egyre nagyobb a z-tengely mentén történő mozgás. Azon részecskék esetén, amelyeknél ez jellemzô, a z irányú elmozdulás a mozgásuk végén figyelhetô meg.

A folyadék-gáz határfelület közelében kialakult nagy sebességgradiens miatt a PIV módszert nem tudtuk használni olyan módon, ahogyan azt a kísérlet tervezésekor elképzeltük. Továbbá mivel az yz-síkban nem volt lehetôségünk PIV felvételek készítésére, csak hosszirányú folyadékmozgásról kaphattunk információt. A folyadékmozgás három dimenziós leírásához tehát a cellák középvonalában elhelyezett lézerrel párhuzamosan y irányban $\pm 1,5 \mathrm{~mm}$ re világító lézerek mentén kialakuló áramlásokat kellett vizsgálnom. Ehhez szintén a PTV technikát alkalmaztam a PIV felvételek felhasználásával. A áramlás erősségének leírásához a részecskék abszolút elmozdulását határoztam meg a középső lézer mentén elhelyezkedő részecskék elmozdulásához képest. Ezen mérések során lényeges szempont volt, hogy a vizsgált részecskék ugyanarról a területrôl származzanak, és lehetőleg azonos mélységben helyezkedjenek el. Ezen kritériumoknak az egyébként is kevés részecskéből csupán néhány 


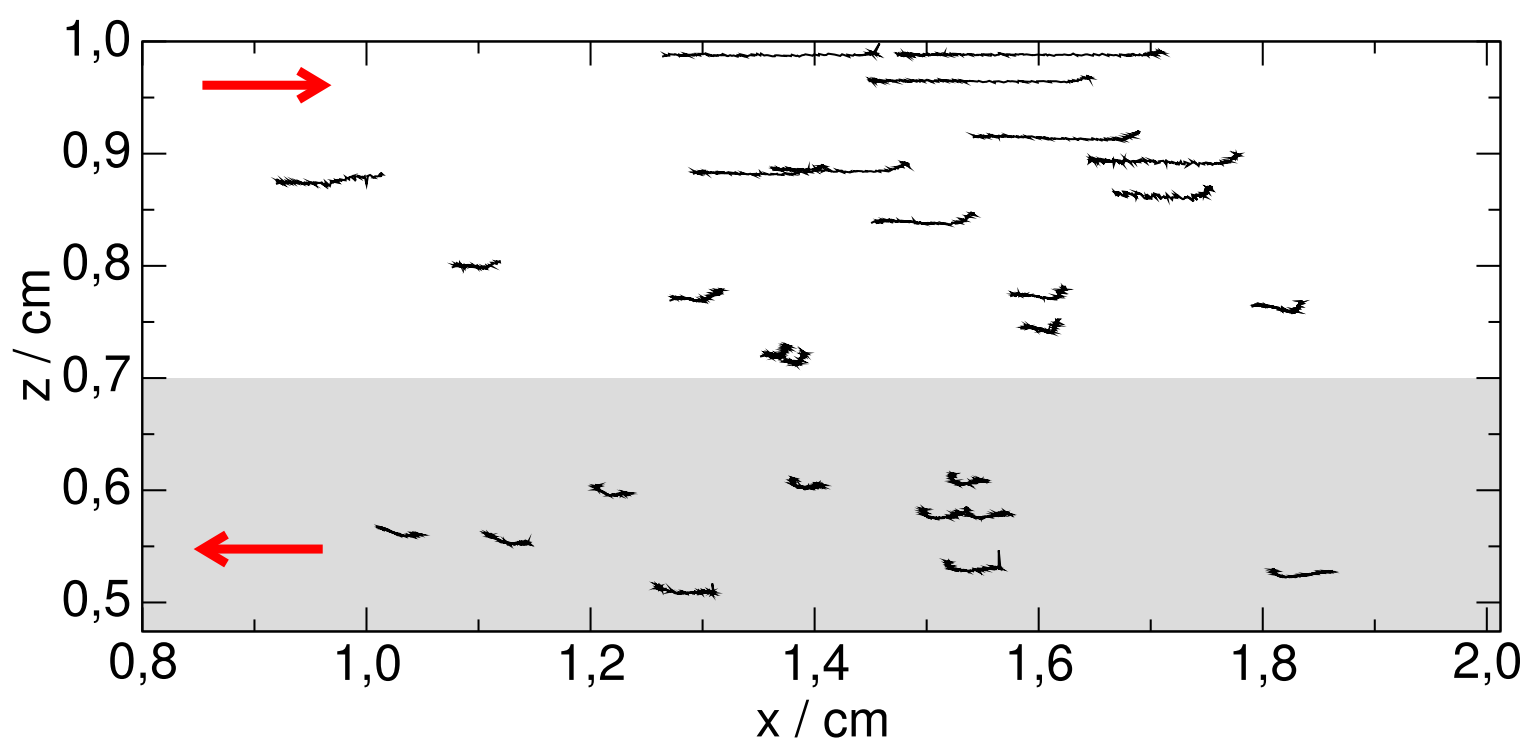

7.16. ábra. A PTV mérések során követett részecskék által a kísérlet teljes idôtartama alatt bejárt út a $10 \mathrm{~mm}$ széles cellában. A fehér háttérrel jelölt területen a részecskék jellemzô elmozdulása a növekvő $x$ értékek irányába történik, míg a szürke háttérrel rendelkező részecskék ellenkezô irányban mozognak.

felelt meg. Bár a lézerek elhelyezkedésének geometriája megegyezik a két cellában, azonban a cellák mérete eltérô az y irányban, így a fent leírt módon elvégzett vizsgálatok eredményeiben szignifikáns eltérés várható. Az $5 \mathrm{~mm}$ széles cellában a lézerek által lefedett terület a teljes keresztmetszet 70\%-a, míg a 10 mm széles cellában csupán 35\%-a. Ebből adódik, hogy az előbbi cellában a szélsô lézerek távolsága a cella falától $0,75 \mathrm{~mm}$, míg a $10 \mathrm{~mm}$ széles cellában ez az érték 3,25 mm. A fal hatása a szélső lézerek által megvilágított részecskék mozgására várhatóan szignifikánsan nagyobb a keskenyebb cella esetében. A mérések eredménye a 7.17. ábrán látható. Az 5 mm széles cellában a részecskék elmozdulása a szélső lézer mentén jóval kisebb mint a cella középvonalában világító lézer mentén elmozduló részecskéké. A felszín közelében 50\%-os a különbség míg nagyobb mélységekben ez 70-80\% közé nô. Ezzel szemben a szélesebb cellában a részecskék elmozdulását tekintve minimális differencia mutatkozik a két lézersík mentén. A legnagyobb különbség sem éri el a 20\%ot, a felszín közelében pedig minimális különbség mutatkozik. A két cella között tapasztalt eltérések egyértelmúen a fal lassító hatásából adódnak.

A folyadékáramlás alapvető tulajdonsága annak lamináris vagy turbulens jellege. A mérések során kapott sebességértékekkel meghatározható a Reynolds-szám. A folyadék-gáz határfelülettel rendelkező cella egy felülrôl nyitott csatornának felel meg. Ilyen körülmények között a Reynolds-számot a következő összefüggés adja meg:

$$
\operatorname{Re}=\frac{\nu R_{h}}{\mathrm{v}}
$$



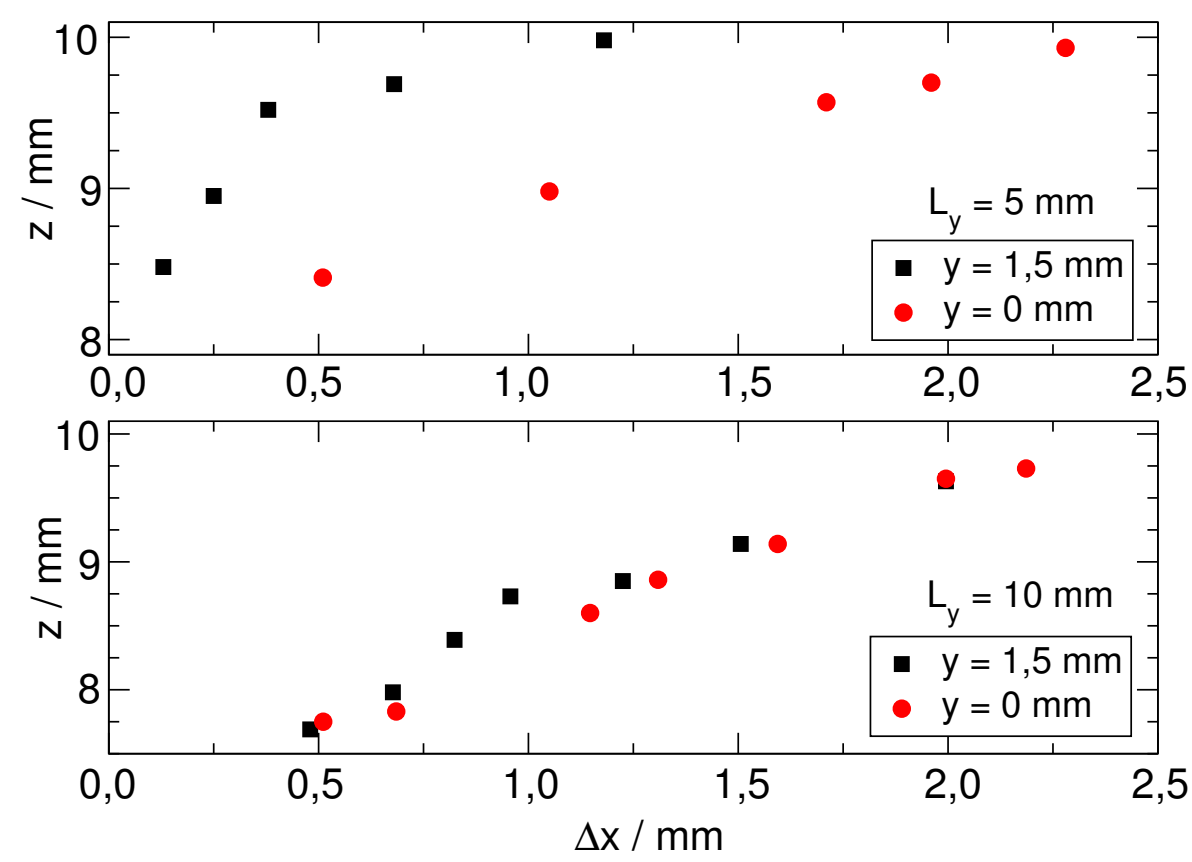

7.17. ábra. A részecskék elmozdulása a kísérlet időtartama alatt a két eltérő pozíciójú lézersík mentén a két különböző méretû cellában.

A (7.5). egyenletben $v$ az átlagos áramlási sebesség, $v$ dinamikai viszkozitás és $R_{h}$ a hidraulikus keresztmetszet, amely az áramlási keresztmetszet és a nedvesített kerület hányadosa. Mivel átlagos áramlási sebesség nem áll rendelkezésemre, a Reynolds-szám meghatározásakor a maximális sebességet használtam. Ez alapján a $10 \mathrm{~mm}$ széles cellában igen alacsony 0,1-es érték adódott. Ez a nyitott csatornában jóval a lamináris-átmeneti áramlás határértéke $(R e=500)$ alatt van. Eszerint kijelenthetô, hogy az áramlás lamináris jellegú.

A másik alapvető jellemző, amely a Marangoni-instabilitás erősségét adja meg, az a Marangoni-szám $(M a)$, melyet Pópity-Tóth és társai az alábbi módon definiáltak [82]:

$$
M a=\frac{\Delta \gamma}{\eta v_{f}}
$$

ahol $\gamma$ a felületi feszültség értéke, $\eta$ a dinamikai viszkozitás és $v_{f}$ a front terjedési sebessége. Ez az érték Földi körülmények között tízezres nagyságrendû míg mikrogravitációban jellemzően egy nagyságrenddel nagyobb. Méréseim alapján a $10 \mathrm{~mm}$ széles cella esetében ez az érték 140000. 


\subsection{Numerikus szimulációk eredményei}

A 6. fejezetben bemutatott peremfeltételekkel és kezdeti értékekkel felépített modell megoldásával rekonstruálhatók mind a koncentrációviszonyok, mind pedig a gerjesztett folyadékáramlás a reakció lejátszódása során. Ezáltal a szimuláció alkalmas arra, hogy leegyszerúsített körülmények mellett megértsük a vizsgált jelenség dinamikáját. Az inhomogén koncentrációeloszlás által keltett folyadékáramlások elsődleges indikátora a front alakjában bekövetkező torzulások, így a kísérletek során az egyik legfóbb információforrás a frontalakról készített felvételek voltak, melyeken színváltozás segítségével határoztam meg a front mindenkori helyzetét. Számításokban a reakciófront helyének és alakjának a kinyeréséhez, a jód koncentrációmezejében kerestem $x$-irányban a színváltásnak megfelelő változást a koncentrációértékekben. A kétdimenziós frontalak meghatározásához a cella közepének megfelelő síkból nyertem ki az adatokat. Így a szimuláció eredményeként kapott reakciófront tér- és időbeli-változása összevethető a kísérletek során nyert frontprofilokkal.

A front alapvetô terjedési tulajdonságai jó egyezést mutatnak a kísérletek során megfigyeltekkel. A frontalak ez esetben is leírható két egyenes vonallal és az alakzat folyadék-gáz határfelülethez közeli részén dôl a haladási irányával megegyező irányba. Révén, hogy a számítások során a jódkoncentrációban a front két oldalán kialakult gradiens már $t=0$ időpontban is maximális, a szimulációk során a front felső szakaszának dőlését előidéző hatás már az első pillanattól jelen van. Szintén a tranziens időszak hiánya az oka annak, hogy a frontsebesség is már rövid időn belül eléri a maximális értéket. A kísérletekben a frontsebesség a $10 \mathrm{~mm}$ széles cella esetében körülbelül 150 másodperces tranziens állapot után éri el az állandósult értéket. A számolásokban az átmeneti állapot csupán 20-25 másodperc.

Az alkalmazott algoritmus az összes számítási cellában megadja a sebességvektor három térbeli komponensét, így a rácsháló felbontásának megfelelő pontossággal rekonstruálható az instabilitás által indukált áramlási kép. Ezt a számítások során kapott áramlási képet a kísérletekben alkalmazott PIV technika eredményeivel vetettem össze. Tekintettel arra, hogy PIV mérésbôl származó eredmény is két dimenzióban áll rendelkezésre, a szimulációkban is egy-egy az xz-síkban kinyert áramlási képet használtam összehasonlításra.

A 7.18. ábrán megjelenített sebességvektorok képe egy, az óramutató járásával megegyező forgásirányú konvekciós gyưrú jelenlétét mutatja, mely egybevág a PIV mérés során kapott eredményekkel. Azonban a konvekciós gyưrü nem egy olyan elnyújtott alakkal rendelkezik, amely az a 7.12. ábrán is látható, hanem egy szabályos kör alakú gyưrú. Az eltérés abból adódik, hogy a PIV mérés során a 10 mm széles cella esetében 26,6 másodperc telt el a két felhasznált fotó között. Ez idő alatt a front jelentôs távolságot tesz meg, és a konvekciós gyưrú középpontja is mozog. A szimuláció azonban lehetôséget nyújt arra, hogy a mindenkori pillanatnyi áramlási képet rajzoltassuk ki. A kapott eredmények alapján a számolások 


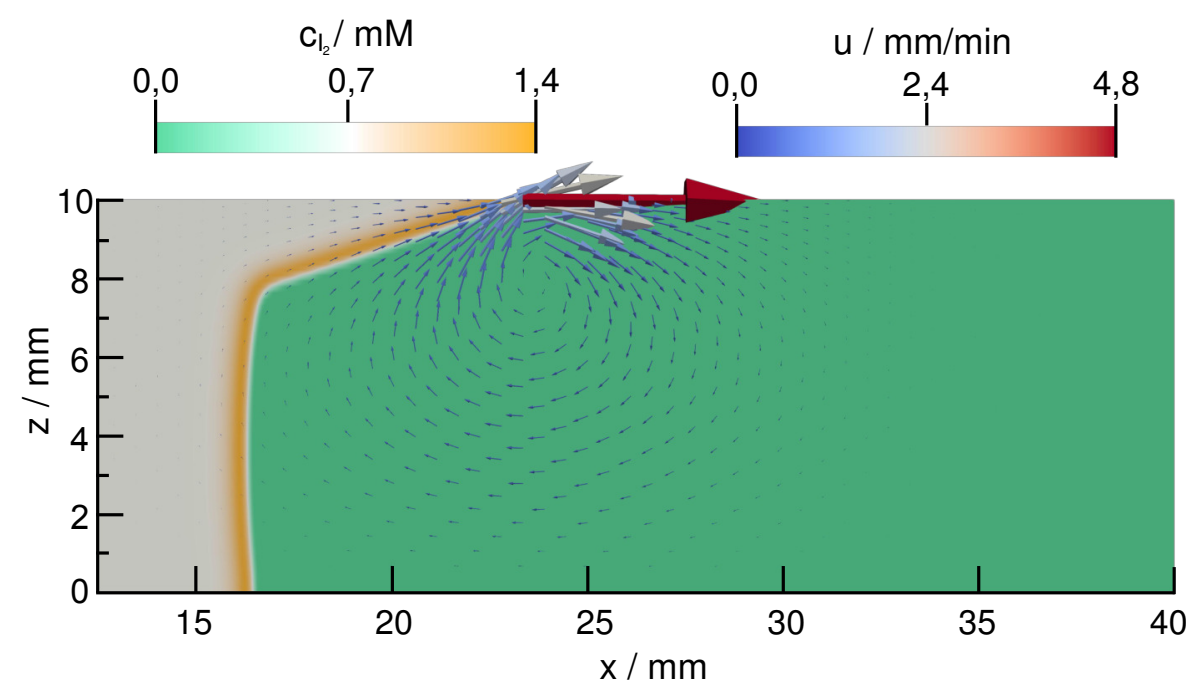

7.18. ábra. A szimuláció eredményeként kapott jód koncentrációeloszlás és a kialakult áramlási tér a 10 mm széles cellában annak középvonala mentén kivágott síkban a front iniciálását követô 120. másodpercben. Az y-tengely pozíciója $(x=12,5 \mathrm{~mm})$ a kísérleti geometriában éppen az iniciálásra használt platina rúd szélének felel meg.

is alátámasztják a konvekciós gyưrú nagy fokú aszimmetriáját, és ezekből az eredményekből látszik csak igazán, hogy a jelentôs áramlások mennyire a folyadék-gáz határfelület közvetlen közelébe korlátozódnak. A 7.19. ábrán, melyen a modell teljes térbeli felbontását

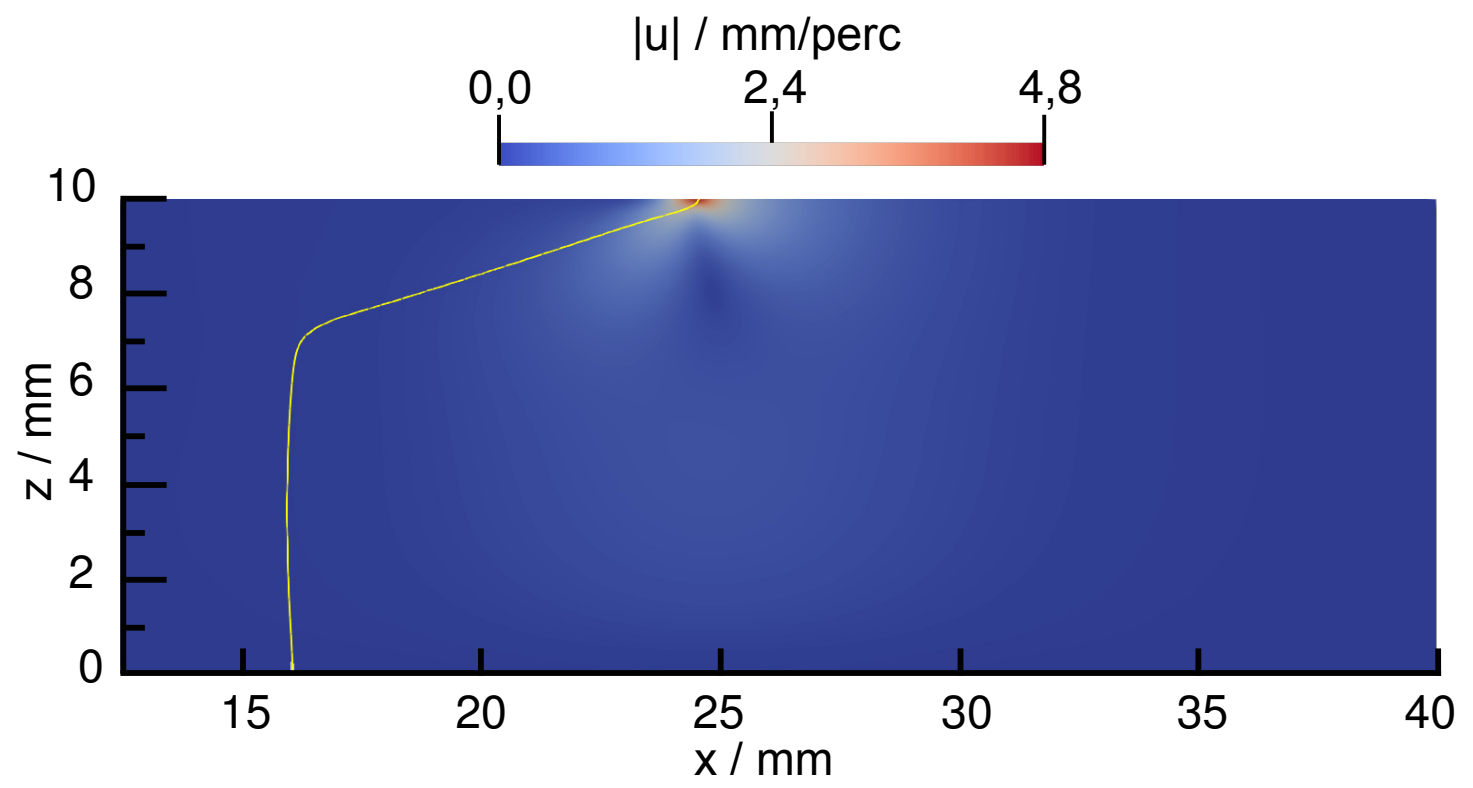

7.19. ábra. A reakciófront helye (-) és a folyadékáramlás sebessége a szimulációk eredménye alapján az $5 \mathrm{~mm}$ széles cellában a cella középvonala mentén kivágott síkban a front iniciálását követő 135. másodpercben. Az y-tengely pozíciója $(x=12,5 \mathrm{~mm})$ a kísérleti geometriában éppen az iniciálásra használt platina rúd szélének felel meg. 
kihasználva ábrázoltam a számított áramlási sebességértékeket, talán még szembetúnőbb ez a nagy inhomogenitás.

A front alakját torzító áramlások egyértelmúen a folyadék-gáz határfelületen jelenlévő erôk hatására indulnak be. A front terjedésével azonos irányú elmozdulás miatt ellentétes áramlások is jelen vannak a rendszerben. E folyadékmozgás a nagyfokú aszimmetria miatt azonban jóval gyengébb, mint a felszínen, hatása a front alakjára elenyészó. A reakciófront alsó szegmensénél az áramlási sebesség a kizárólag reakció-diffúzió mechanizmus esetén jellemző frontterjedési sebesség csupán néhány százaléka. A 7.20. ábrán látható, hogy a folyadék sebessége a maximális sebesség helyétôl mindössze néhány tized milliméter alatt csökken a reakció-diffúzió által hajtott frontterjedési sebesség $\left(u_{R D}\right)$ alá. Mind mélységben, mind pedig oldalirányban körülbelül három milliméteres távolságban az áramlási sebesség már csak 20\%-a a konvekció által nem befolyásolt front sebességének.

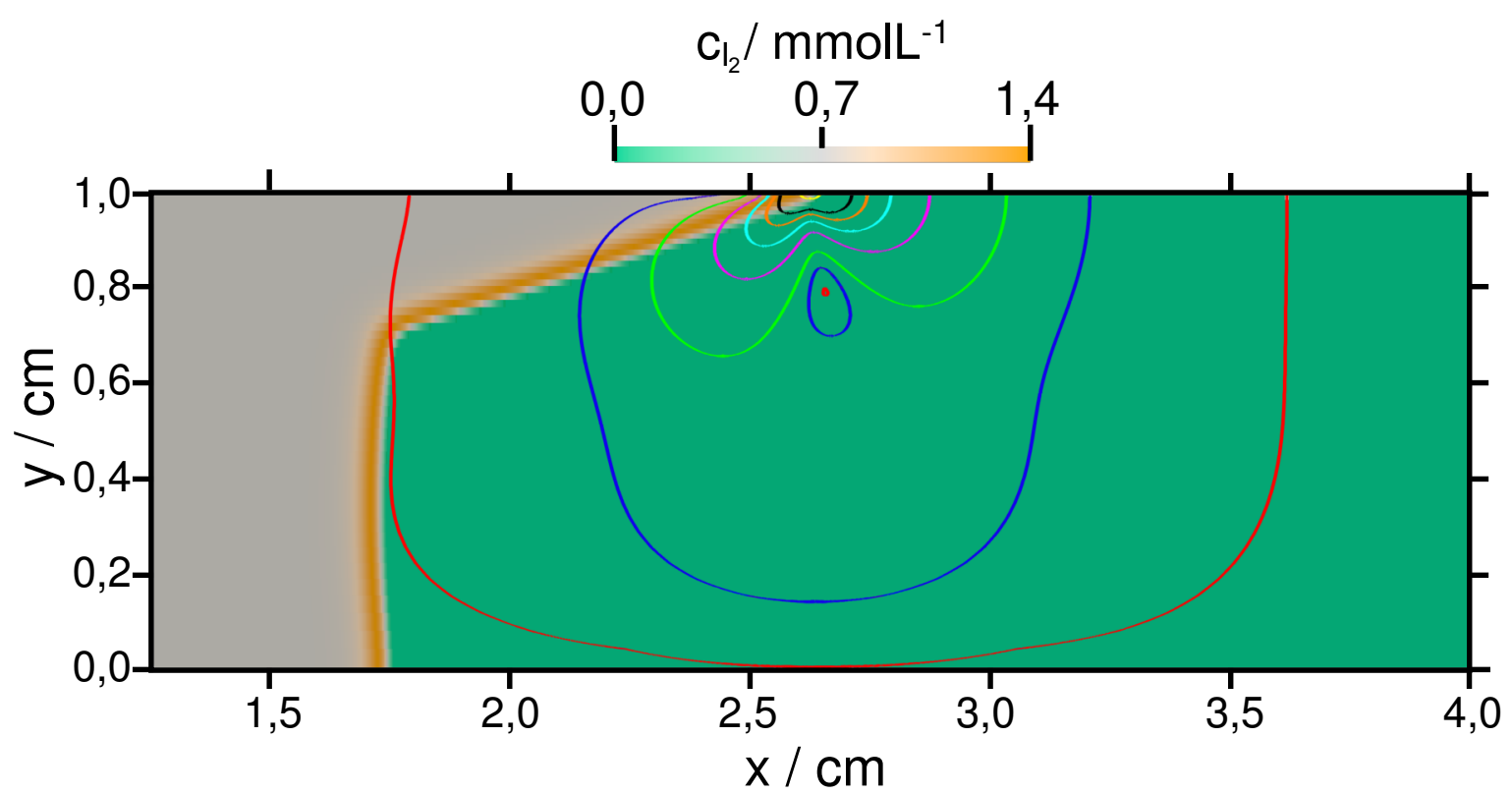

7.20. ábra. A folyadék áramlási sebessége a tisztán reakció-diffúzió által vezérelt front haladási sebességéhez viszonyítva a $10 \mathrm{~mm}$ széles cellában az iniciálást követő 135 . másodpercben. Az izovonalak a következő $|\vec{u}| / u_{R D}$ értékeket jelölik: 0,02(一), 0,1(一), 0,2(一), 0,4(一), $0,6(-), 0,8(-), 1,0(-), 2,0(-)$

A PTV technika segítségével meg tudtam határozni a részecskék mozgását a vizsgált képsorozaton, melynek eredményeképp megkaptam a részecskék maximális sebességét, amit a 7.15. ábrán be is mutattam. Feltételezhetô, hogy a nem ülepedô, a folyadékkal közel azonos sûrûségû részecskék sebessége megegyezik a folyadék áramlási sebességével. Ennél fogva a részecskék sebessége összehasonlítható a számítási geometria soraiban számolt maximális sebességértékekkel. A 7.15. ábra számításból kapott maximális sebességértékekkel 
kiegészített változata a 7.21. ábra.

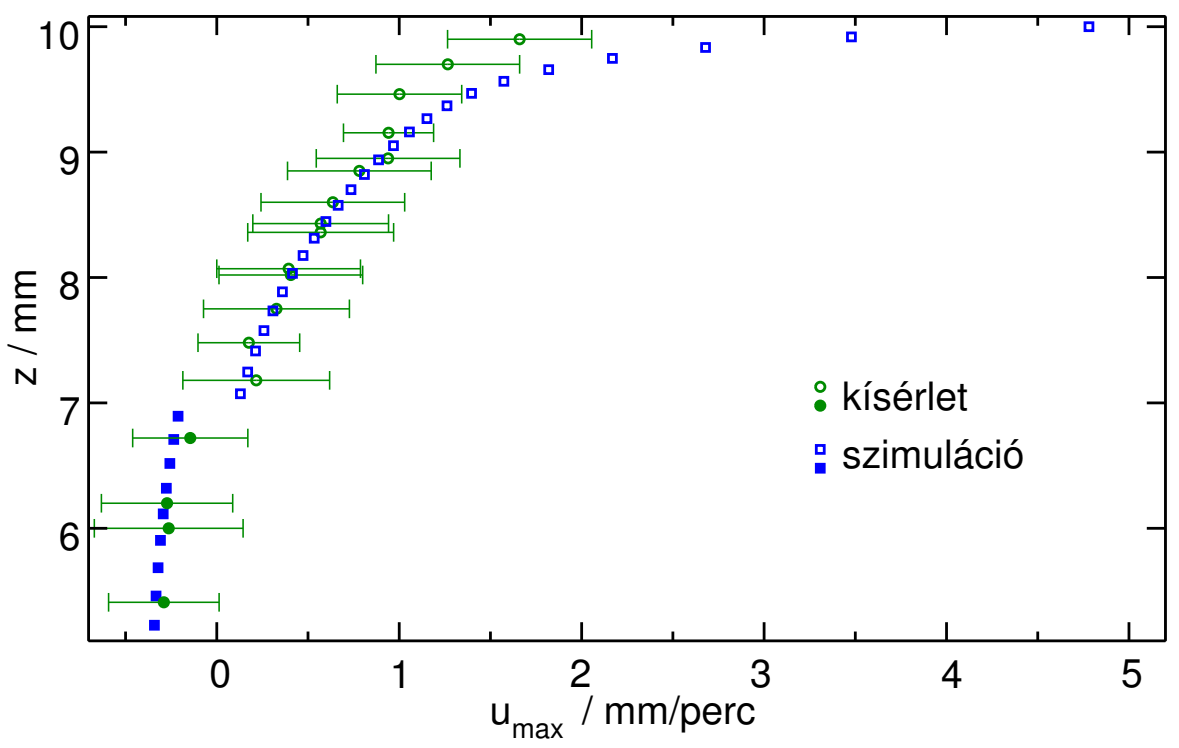

7.21. ábra. A kísérlek során, a részecskék mozgásában mért maximális sebességek, illetve a szimuláció eredményeként kapott maximális sebességértékek. A teli kör a negatív irányba mozgó részecskéket reprezentálja, a teli négyzet pedig azokat a cellákat, ahol a visszaáramlás sebessége meghaladja a pozitív $x$ irányú áramlás sebességét.

A szimulációkban kapott sebességeloszlás az egyéni részecskekövetésen alapuló technika által biztosított sebességeloszlással jó egyezésben van. A 7.21. ábrán is körül belül $y=7$ mm-nél rajzolódik ki a konvekciós gyưrü közepe. A sebességértékeket tekintve $y=9 \mathrm{~mm}$-ig a szimuláció kiváló egyezést mutat, azonban a felsô egy milliméterben, ahol a legnagyobb a sebességgradiens, ott szignifikánsan megnő az eltérés a mért és számított értékek között. Ennek egyik oka, hogy olyan részecskét amely közvetlenül a folyadék-gáz határfelületen helyezkedik el, nem tudtam megfigyelni és kielemezni a PTV technikával. A másik ok, a biológiai kísérlet moduljából, érkező rázkódás lehet, mely egyébként is nagy hibával terhelte a mért értékeket, és melynek lehetséges, a részecskék sebességét befolyásoló hatását nem tudtam felmérni.

Ahhoz, hogy teljes képet kapjunk a kialakult áramlási képről, kihasználtam az OpenFOAM programcsomaghoz használt ParaView univerzális kiértékelő program nyújtotta azon funkciót, amely az áramlási térben, különböző pontokba elhelyezett részecskék által bejárt pálya megjelenítését teszi lehetôvé. A 7.22. ábrán a kísérleti PTV mérések és a szimuláció során meghatározott útvonalakat hasonlítom össze és látható, hogy a modell jó egyezéssel adja vissza részecskék által megtett utat. A virtuális részecskék kezdeti pontjai megegyeznek a PIV részecskék által, az első képkockáján elfoglalt pozícióval. Akadnak részecskék, ahol úgy tűnik, hogy a kezdeti helyzetben is van eltérés. Ennek oka, hogy a PTV eredmények a részecskék fényintenzitás-változásából adódóan 3-5 pixelnyi hibával terheltek. A kísérlet 


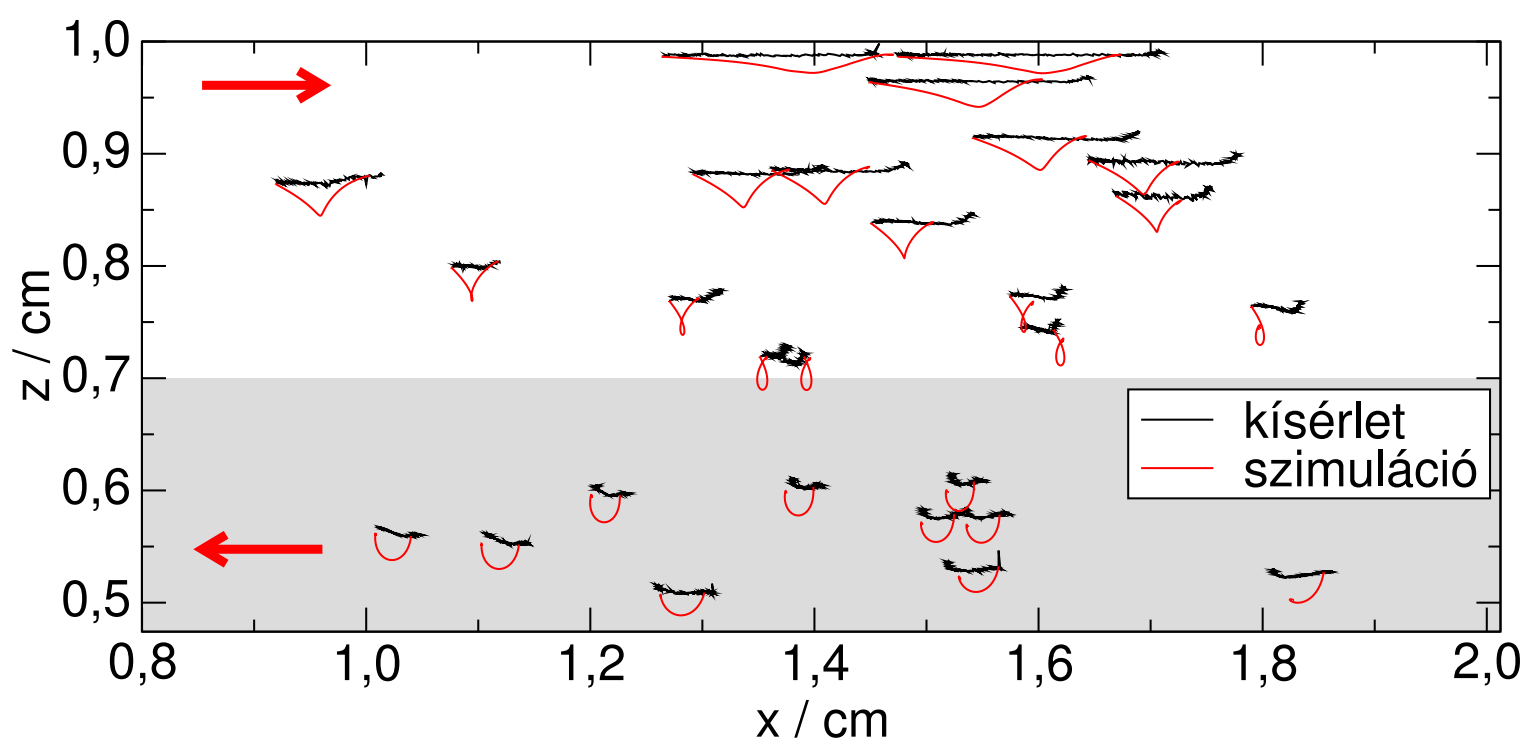

7.22. ábra. A kísérletben meghatározott részecske pályák, illetve a szimulációban azonos kezdeti pozícióban elhelyezett részecskék által bejárt pálya, a kísérlet idôtartama alatt. A fehér háttérrel rendelkezô részecskék fố elmozdulási iránya jobbra, a szürke háttérben elhelyezkedô részecskéké balra van.

végén mérhetô részecske pozíciók azonban kis eltérésekkel, de egy helyre esnek. Látványos különbség, hogy a modellezett részecskék mozgásában több a z-irányba történő elmozdulás mint amennyit a valóságban mérhettünk.

A modellszámításokkal egyik fontos célunk a kétdimenziós mérési adatok három dimenzióra való kiterjesztése volt. Két dimenzióban DeWit és társai már sok tanulmányban vizsgálták az összetétel különbség által generált Marangoni-instabilitás hatását [53, 54]. A rakétakísérlet során a mérésinket mi is két dimenzióban végeztük. A PIV mérésekben alkalmazott három lézersík által szolgáltatott adatok az xz-síkból származnak, így nem adnak teljes képet a kialakult térbeli áramlásról. S bár a részecskék lézersíkok között is elmozdulnak nem létezik olyan algoritmus, amely megfelelô pontossággal adná vissza az $y$-irányban elmozduló részecskék mozgását. A felépített modell alapján végzett szimulációk segítségével azonban képesek vagyunk részleteiben megismerni a folyadékáramlás tulajdonságait. A PTV mérésekből rendelkezésre áll különbözô részecskék elmozdulás értéke a két lézersík mentén a 7.17. ábrán. A szimuláció eredményeiben is vizsgáltam a cella falának áramlásra gyakorolt hatását. A 7.23. ábrán az y irányú sebességeloszlást ábrázoltam. Ehhez az yx-sík mentén kinyertem a szomszédos cellákból a sebességvektor $x$ komponensének értékeit, majd megvizsgáltam, hogy mennyire illik a pontokra a két sík fal között lamináris áramlás esetén jellemző parabola sebességprofil. Az illesztett görbére jellemző korrelációs koefficiens mindkét esetben 0,999-nél nagyobbnak adódott. Ennél fogva elmondható, hogy a szimuláció sík falak közötti lamináris áramlásnak megfelelő sebességprofilt ad. A keskenyebb cellában 

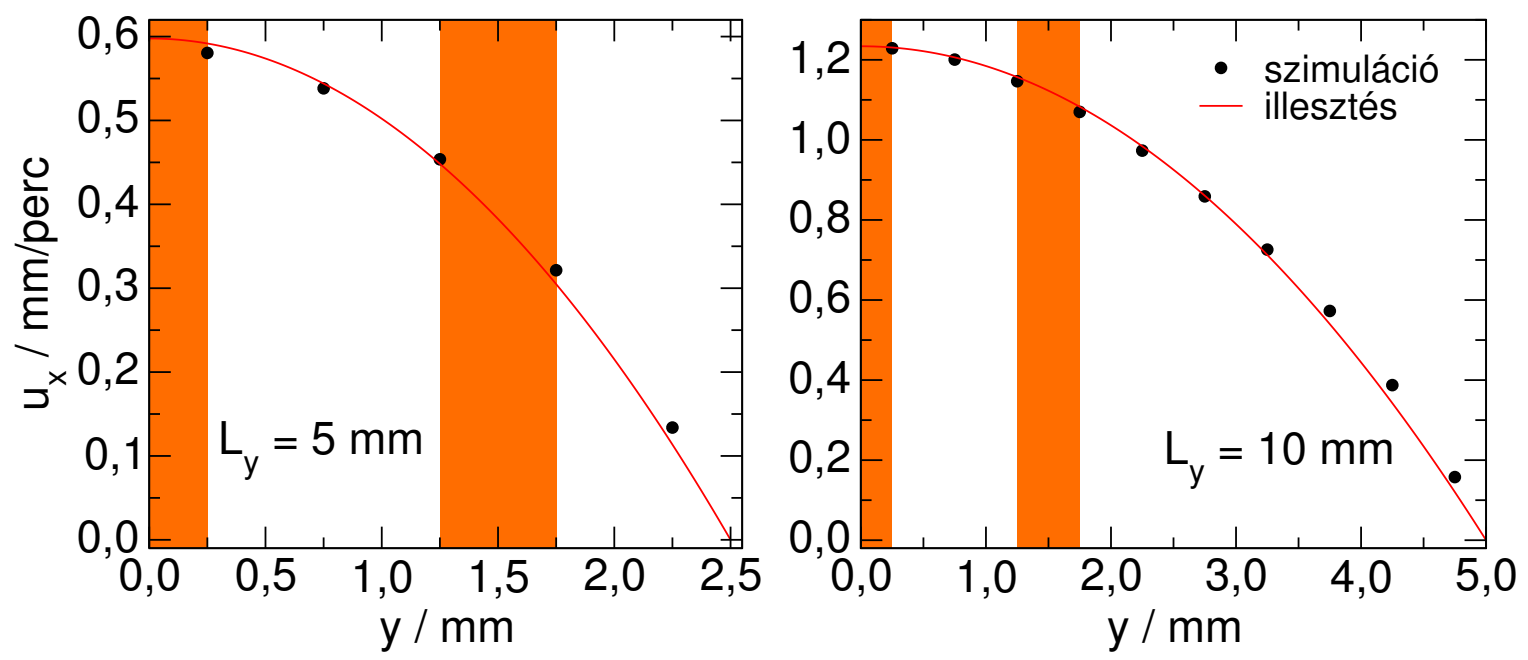

7.23. ábra. A szimulációban kapott sebességértékek ( $\bullet$ eloszlása az yx-síkban $z=9,96$ mmnél, $x=24,9$ mm-nél a két eltérő méretú geometriában az iniciálást követő 120. másodpercben. A pontokra illesztett parabolával (-) és a lézersíkok keresztmetszeteivel (sárga sávok).

a szimulációk eredményei alapján a szélső lézer mentén a sebesség a középső lézerhez képest $\sim 33 \%$-kal csökken a fal hatása miatt. A széles cellában ugyanebben a mélységben vett sebességprofil alapján ugyanez a sebességcsökkenés csupán $\sim 9 \%$. S bár a két paraméter közvetlenül nem összehasonlítható, azonban ha a két lézersík mentén azonos mozgást feltételezünk, a részecskék $y$-tengely menti teljes elmozdulásai és a szimulációban kapott sebességeloszlás között jó egyezés mutatkozik. A parabolaprofilnak megfelelố sebességeloszlást az yx-síkban a reakciófront folyadék-gáz határfelületen kapott alakja is jól tükrözi. A 7.24. ábrán a sebességeloszlás mellett a front aktuális helyzetét is feltüntettem. Amellett, hogy ez esetben is a lamináris áramlásra jellemzó profil rajzolódik ki, az is látszik, hogy a front alakja is ezt az eloszlást követi igazolva, hogy a front alakját torzító hatás a folyadékáramlás.

A szimuláció eredményei alapján a különbözős síkokból vett koncentrációeloszlás megjelenítés mellett kirajzoltatható a reakciófront térbeli, háromdimenziós alakja is. Ehhez szintén a ParaView megjelenítő és kiértékelő programot használtam. A szoftver lehetôséget ad a kiszámított skalármezőkben beállított küszöbérték alatti vagy a feletti értékkel rendelkező cellák megjelenítésére. Ez a funkció kiválóan alkalmas a termékoldatrész és ez által a front térbeli kiterjedésének megjelenítésére. Ez alapján készült felvétel látható a 7.25. ábrán. A reakciófront térbeli kiterjedésérôl elmondható, hogy a folyadék-gáz határfelületen, a lamináris áramlásnak megfelelő görbület jellemző. A front dőlt (a $z$-tengellyel nem párhuzamos) szakaszára is jellemző egy kis fokú görbület a terjedés irányába. A front alsó részén a hengerpalástról iniciált front konvekciótól mentes geometriai terjedésének megfelelően közel henger alakú alakzat a jellemző. A reakciófront alakjának ilyen jellegú háromdimenziós leírása nem lett volna lehetséges a szimulációk elvégzése nélkül. Valódi kísérleti körülmények között a háromdimenziós frontalak meghatározása csak bonyolult kísérleti elrendezéssel, a 


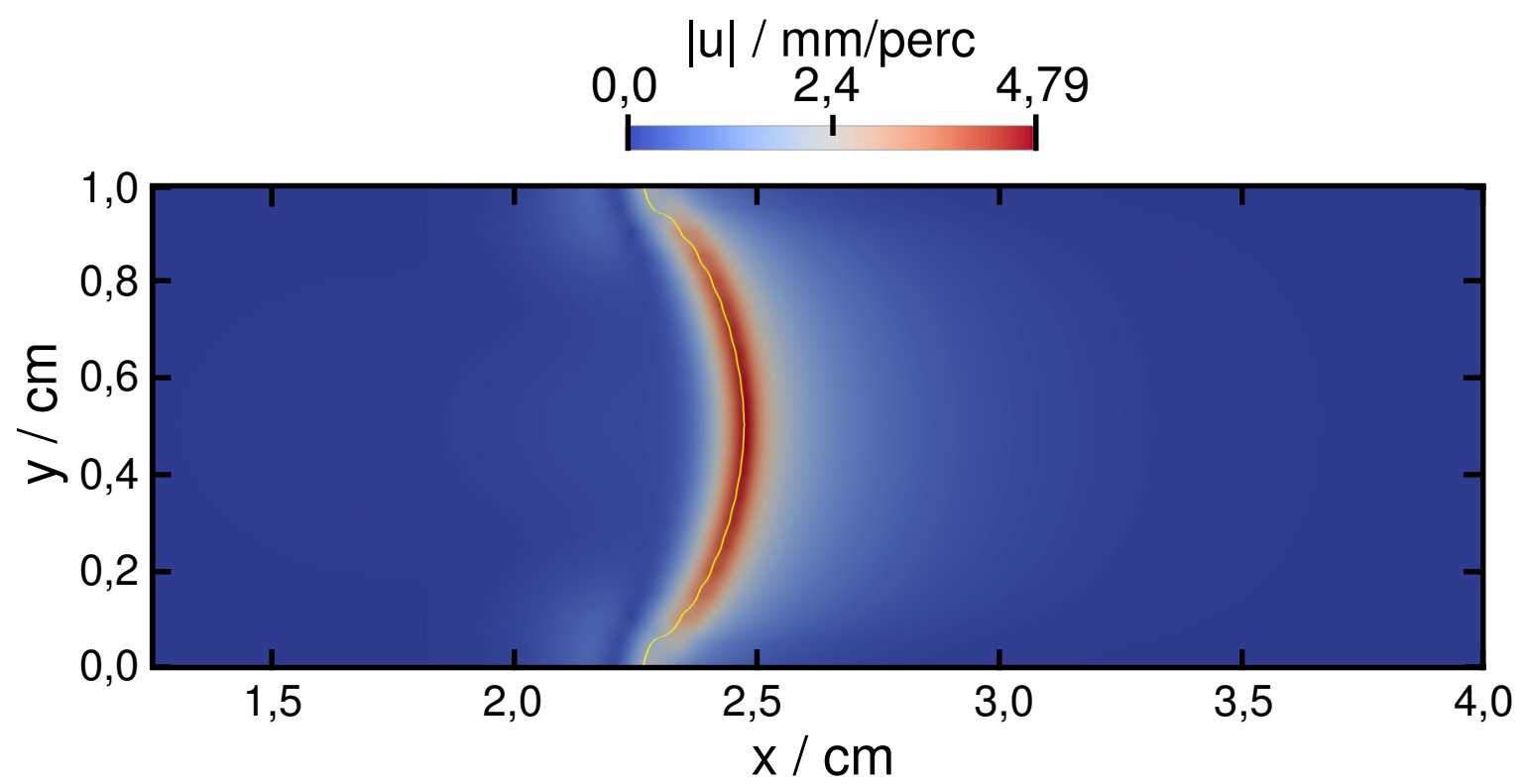

7.24. ábra. A szimuláció eredményeként kapott frontalak (-) és sebességeloszlás a folyadék-gáz határfelületen a 10 mm széles cellában az iníciálást követő 135 . másodpercben.

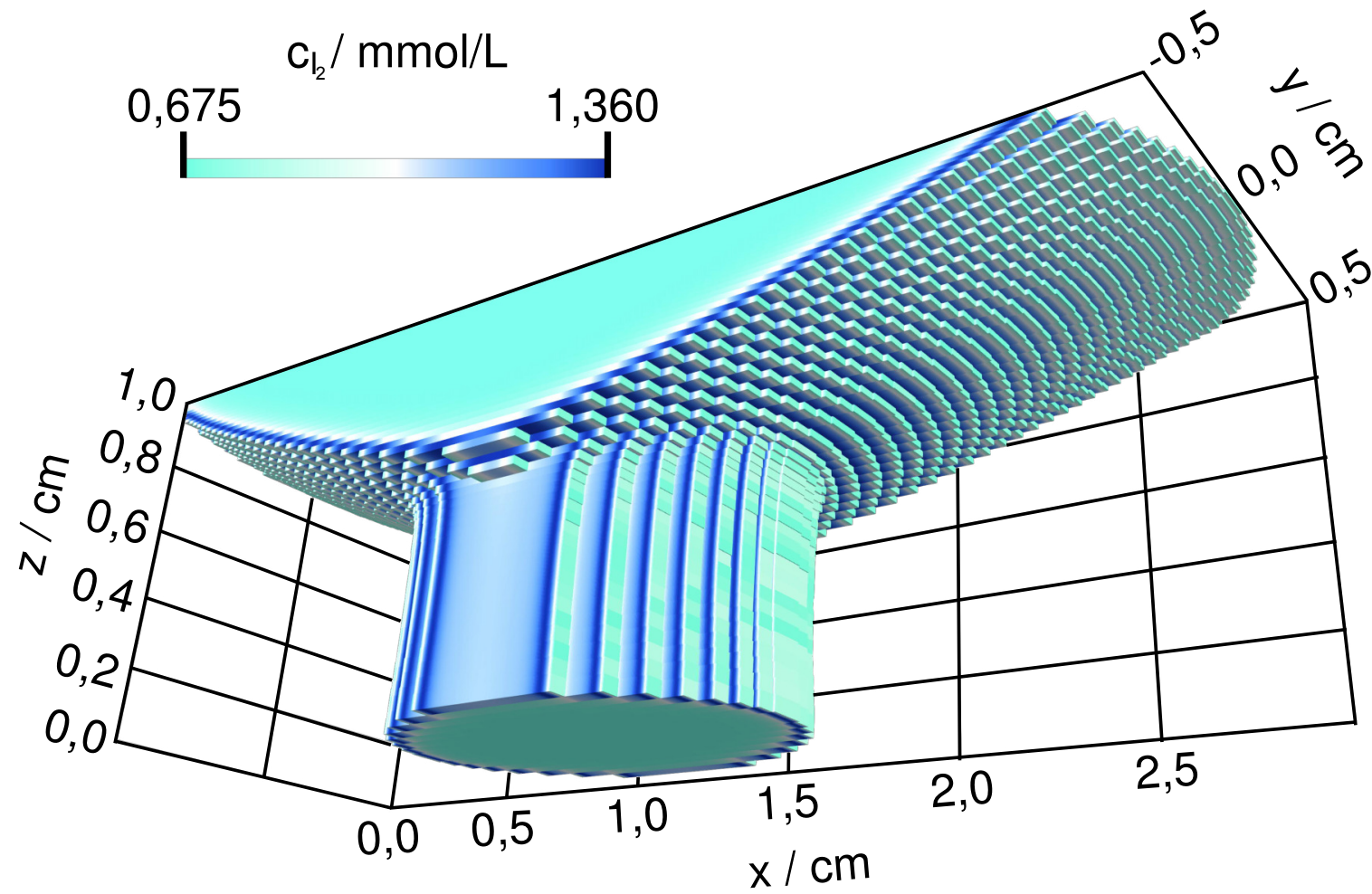

7.25. ábra. A szimuláció eredményeként kapott háromdimenziós frontalak alsó oldalnézetből, melyet a $0,675 \mathrm{mmol} / \mathrm{dm}^{3}$-nél kisebb jódkoncentrációval rendelkező cellák elhagyásával nyertem. Az ábrán a 10 mm széles cellában, az iniciálás utáni 180. másodpercben jellemző állapot látható. 
kialakult áramlási mező megjelenítése pedig több párhuzamos, vagy több ismétlés után lett volna lehetséges. Előbbinek a korlátozottan rendelkezésre álló hely, utóbbinak pedig a rakétakísérletek igen magas költsége szab határt. Az elkészült modell egyaránt alkalmas a Rayleigh-Taylor- és a Marangoni-instabilitás hatásának vizsgálatára bármilyen reakció esetén, hiszen figyelembe veszi a sûrúségváltozást, a felhajtóerôt pedig csupán a gravitációs gyorsulás nullához közeli értékre történő állításával egyszerúen kiküszöbölhető. 


\section{8. Összefoglalás}

A földi élet kifejlődésében alapvető szerepe volt a transzportfolyamatoknak. Ugyanakkor ezek a folyamatok a mai napig közvetlen befolyással vannak mindennapi életünkre. Az időjárási folyamatok határozzák meg számos közlekedési formánk hatékonyságát, a mezőgazdaság teljesítőképességét, mely az emberiség élelmezésére van nagy hatással. Számos katasztrófa helyzet kialakulásáért is ugyanezen jelenségek szélsőséges esetit tehetjük felelőssé. Ezek nagy léptékú, jól látható folyamatok. Vannak azonban az emberi szem elôtt rejtve lejátszódó anyagmozgások. Például felszín alatti vizeink áramlása, mely a tiszta ivóvizet biztosítja számunkra. Ezen vízkészletek a növekvő iparosodás miatt egyre nagyobb terhelésnek vannak kitéve a különböző vegyi anyagok felszín alá történő beszivárgása által. Sajnos mivel a felszín alatt történik mindez, nem tulajdonítunk neki kellően nagy jelentőséget. Belátható azonban, hogy a tiszta ivóvíz rendelkezésre állása igen fontos az emberiség számára. Egy-egy sajnálatos atomerőmúvet ért baleset során a levegôbe kerülô radioaktív szennyezés is csak a mérőmúszerek által mutatható ki. Az ilyen szennyezések terjedésének pontos előrejelzésével tehetôk csak meg a szükséges óvintézkedések. Általánosságban elmondható, hogy a szennyezések terjedése komplex folyamat, legyen szó folyadékfázisban vagy levegôvel való terjedésről. Szabatos leírásuk csak a részfolyamatok alapos megértése után lehetséges. Egy ilyen részfolyamat, a Marangoni-instabilitás által keltett folyadékáramlás vizsgálatát tûztem ki célul dolgozatomban.

A jelenség régóta ismert a nemlineáris dinamika területén: egy autokatalitikus reakciófront terjedése során két eltérô fizikai tulajdonságokkal rendelkező folyadékrészt választ el egymástól. Amennyiben a folyadékfázis felszíne nyitott, tehát gázfázissal érintkezik, a felszínen felületi feszültségben míg a tömbfázisban a folyadékrészek sûrúségében alakul ki gradiens a reakciófront terjedésének irányában. Sưrüséggradiens esetén bizonyos elrendezésben hidrodinamikailag instabil rétegződés alakul ki, melyet Rayleigh-Taylor-instabilitásnak nevezünk. Az instabilitás megszüntetésére a felhajtóerő miatt folyadékáramlás indukálódik, mely a kialakult reakciófront alakját torzítja. A sűrúségkülönbséggel ellentétben a felületi feszültségkülönbség esetén nem létezik stabil elrendeződés. A kisebb felületi feszültséggel rendelkező folyadékrész a felszínen a nagyobb felületi feszültség értékkel rendelkező folyadékrész felé mozdul el. Ezt nevezzük Marangoni-instabilitásnak. Az így keletkező folyadékáramlás szintén torzítja a front alakját. A két instabilitás összetételváltozás során egyszerre van jelen, így frontot torzító hatásuk is együttesen jelentkezik. Mivel a RayleighTaylor-instabilitás hatása jóval nagyobb mint a felületi feszültségkülönbségből adódó áramlások, ezért az dominál és elnyomja az utóbbit. Földi körülmények között így a két jelenség vizsgálata nagy nehézségbe ütközik. Kísérleteimmel a csoportunkban már vizsgált jodátionarzénessav reakcióban kialakuló áramlásokat tanulmányoztam. A reakció során mind a felü- 
leti feszültség, mind a sưrúség csökken, így a termékoldatrész feláramlással a felszínre és a front terjedésének irányába mozdul el ugyanilyen irányú áramlást keltve.

Munkám során a Rayleigh-Taylor-instabilitás kiküszöbölésére mikrogravitációban végeztem kísérleteket az Európai Úrügynökség támogatásának köszönhetően. A gravitációs vonzásból származó, testeket gyorsító erô csökkenthető, ha a testeket szabadesés állapotába hozzuk. Földi körülmények között erre több lehetőség is adódik, nekem parabolarepülések, illetve szuborbitális rakéta-kísérlet során volt lehetôségem kísérleteim elvégzésére. A parabolarepülés 20 másodpercnyi időtartamban biztosít mikrogravitációt. Azonban ezt hasonló hosszúságú hipergravitációs körülmények előzik meg és követik a repülés pályájából adódóan. Ez a modulált gravitációs erôtér mind a Rayleigh-Taylor-, mind pedig a Marangoni-instabilitás vizsgálatát lehetôvé teszi. A parabolarepülés célja a megfelelő kísérleti elrendezés és paraméterek meghatározása volt, de a reakciófront alakjának és helyzetének vizsgálatával számos megállapítást tudtam tenni. Zárt, légréteg nélküli cellákban végzett kísérletek esetén a frontsebesség a tisztán reakció-diffúzió jelensége által vezérelt front sebességére csökkent a mikrogravitációs fázisban. A felhajtóerőből eredő áramlás megszúnik, így gyakorlatilag a front alakját torzító hatások túnnek el. A front görbületi sugara elkezd növekedni így az ujjas alakzat kisimul. Hipergravitáció esetén a front sebességének növekedést tapasztaltam és megnövekedett áramlási sebesség miatt a frontra egy a normál gravitációs körülmények esetén tapasztalhatóhoz képest elnyújtottabb, lecsökkent görbületi sugarú ujjas szerkezet lesz jellemző. Zárt cellában tehát mikrogravitációban a Rayleigh-Taylor instabilitás megszúnésével tisztán reakció-diffúzió mechanizmus által vezérelt reakciófrontot kapunk.

Nyitott cellában végzett kísérletek esetén nagyon hasonló a front viselkedése mind az alakot, mind a terjedési sebességet illetően. Hipergravitációban egy nagyobb sebességú és kisebb görbületi sugárral rendelkező front halad a normál gravitációs körülmények között terjedőhöz képest. Mikrogravitációban azonban mutatkozik egy szignifikáns különbség, a front sebessége majdnem kétszer nagyobb mint a zárt cella esetén. Ez a Marangoni-instabilitás jelenlétét mutatja. A két instabilitás tehát egyszerre van jelen a jodátion-arzénessav rendszerben nyitott folyadékfelszín esetén. A Marangoni-instabilitás vizsgálatához azonban jó minőségú és megfelelő hosszúságú mikrogravitációs körülményekre van szükség.

További kísérleteimet a MASER-13 nevú szuborbitális rakéta fedélzetén végeztem el. A parabolarepülés során szerzett tapasztalatainkra alapozva egy olyan kísérleti elrendezést alkalmaztunk, melyben tisztán a Marangoni-instabilitás által keltett hatások vizsgálhatók. A rakétakísérlet hat percnyi, a parabolarepülés során elérhetônél jobb minőségú mikrogravitációs körülményeket biztosított. A kísérletek során már nem csak a front alakját és helyzetét rögzítettük, hanem részecskeképen alapuló sebességmeghatározással (PIV-technika) a kialakult folyadékáramlást közvetlenül is tudtuk vizsgálni. A kísérleteket két eltérő méretú 
átlátszó küvetta-szerú mérôcellában végeztük annak érdekében, hogy bizonyítsuk: nem a jód gázfázisbeli diffúziója okozza a front előrehaladását. A kísérlet során azt tapasztaltuk, hogy a front kizárólag a folyadék-gáz határfelület mentén kialakuló áramlások hatására torzult. A reaktív határvonal két részre bontható, egy, az iniciálásra használt Platina szál irányával megegyezố és egy, a front haladási irányába megdőlő szakaszra. A PIV technikában használt részecskék egyedi mozgását vizsgálva kirajzolódott, hogy a jelentős áramlások a folyadékgáz határfelület közvetlen környezetére korlátozódnak, az áramlásnak a tömbfázisban már csak minimális hatással van a reakciófront terjedésére és alakjára. Ezt az is alátámasztotta, hogy egy egyszerú úgynevezett geometriai frontterjedési modellel is jól reprodukálható volt a kísérlet során kapott frontalak.

Mind a parabolarepülések, mind pedig a rakétakísérlet során csupán két dimenzióban álltak rendelkezésemre adatok a reakciófront alakjáról. Annak érdekében, hogy a front alakját és az áramlási mezőt is meg tudjam határozni három dimenzióban, fluiddinamikai modellszámításokat végeztem az OpenFOAM programcsomagban. A modell egy reakció-diffúzióadvekció modell, mely a Navier-Stokes-egyenlet megoldásával határozza meg a sebesség és nyomásmezôt a számítási térben. A számolások során a Boussinesq-közelítést alkalmaztam, így a modell figyelembe veszi a reakció során bekövetkezô sûrúségváltozást és a gravitációs gyorsulás értékétől függően vizsgálható vele a Rayleigh-Taylor-instabilitás hatása. A modell a megadott diffúziós együtthatók, a reakciómechanizmusnak megfelelő differenciálegyenletek és az azokhoz tartozó empirikus sebességi együtthatók segítségével alkalmas az IAA frontreakció szimulációjára. Amennyiben ezek a paraméterek rendelkezésre állnak, más reakciók is vizsgálhatók. Az úgynevezett Marangoni-peremfeltétel alkalmazásával pedig a nyílt, folyadék-gáz határfelülettel rendelkező áramlások vizsgálhatók.

A numerikus szimulációk eredményei jó egyezést mutattak a front kétdimenziós alakját illetően. A Marangoni-instabilitás hatására kialakuló folyadékáramlás sebességeloszlása ez esetben is azt mutatta, hogy az intenzív áramlások a folyadék-gáz határfelület közvetlen közelében jellemzőek. A kialakuló konvekciós gyưrú nagyfokú aszimmetriát mutat. A modell segítségéve bármely idôpillanatban rendelkezésre áll a számolt komponensek koncentrációértékei mellett, a sebesség- és nyomásmező. Ennek köszönhetően a front háromdimenziós alakja is kinyerhető az eredményekből. A kapott koncentrációeloszlás alapján elmondható, hogy a folyadék-gáz határfelületen a lamináris áramlásra jellemző parabolaprofilnak megfelelő görbület jelenik meg a front alakjában. A rendelkezésre álló sebességértékek segítségével a PIV részecskéknek megfelelő virtuális pontok mozgása is számolható, melyek jó egyezést mutatnak a valódi részecskékével. Az elkészített modell tehát egy univerzálisan alkalmazható modell, melynek segítségével a jodátion-arzénessav reakcióban is fellépő instabilitások által keltett áramlások vizsgálhatók térben és időben. 


\section{Summary}

Transport processes have played a key role in the evolution of life on Earth. Furthermore these phenomena still have minor impact on everyday life of humankind. Meteorological processes are main determining factors on the effectivity of different means of transportation and the efficiency of agriculture which affects feeding. The extreme forms of such phenomena are responsible for several catastrophic events. These are large scale and visible processes. However, there are forms in which the motion of material is hidden from the human eye. A good example is the flow of groundwater which is the main source of fresh, potable water. Such resources are exposed to increasing load due to the seepage of pollutants which is a consequence of increasing industrialization. Nevertheless it is evident that the availability of drinking water has high importance for humanity. The radioactive pollutants which are emitted during the incidents involving nuclear power plants are also detectable only with appropriate instrumentation. Preventive actions can be properly done if accurate forecast of the transport of such pollutants is available. In general the spreading of a pollution with air or dissolved in water is a complex phenomena. Highly detailed description can only be done if the subprocesses are fully understood. The objective of my dissertation is the investigation of such a subprocess, namely the induced fluid flow by Marangoni instability.

The fact that a spreading autocatalytic reaction front separates two fluid parts with difference in their physical properties is well known in the field of nonlinear dynamics. In cases when the fluid phase is in contact with the gas phase there is a gradient in the surface tension on the interface, while in the bulk density gradient develops in the direction of front propagation. In certain orientations, the stratification of the two fluid is hydrodynamically unstable. In these cases Rayleigh-Taylor instability occurs. For the elimination of instability buoyant forces arise which are generating fluid flow resulting the distortion of the reaction front. If there is a gradient in surface tension - unlike in the case of density difference- there is no stable stratification. On the interface the fluid with lower surface tension moves towards the fluid which has higher value in surface tension. The fluid flow which is generated by this so called Marangoni instability, also distorts the shape of the chemical front. In a solution with open surface by changing its composition the two instabilities and their distorting effects occur simultaneously. The fluid motion generated by the Rayleigh-Taylor instability has higher intensity therefore this is the dominant effect over the flow arising from the surface tension difference. This is the reason why the the investigation of the two phenomenon is challenging under terrestrial circumstances. During my experimental work I studied the generated fluid flows in the Iodate-Arsenous Acid (IAA) reaction which changes the composition of the solution in a way that both the density and the surface tension are decreasing. The product flows upwards towards the surface where it moves in the direction of the front 
propagation.

During my work to avoid Rayleigh-Taylor instability I conducted experiments under microgravity with the sponsorship of European Space Agency. The force which accelerates all bodies and originates from gravitational attraction can be reduced if the bodies are taken to the state of free fall. On Earth there are several ways to do so. In my work I had the possibility to carry out experiments during parabolic flights and on board of a suborbital sounding rocket. A parabolic flight can provide twenty seconds of microgravity. However, due to the trajectory of the flight the phase of microgravity is between two phases of hypergravity which have the same duration as the free fall has. This modulated gravity field suitable to investigate both Marangoni and Rayleigh-Taylor-instabilities. The main goal of parabolic flight experiments was to find the proper experimental setup and parameters however I was able to make some qualitative determinations by studying the shape of the chemical front. In closed cells where the fluid fills completely the available volume, the velocity of the reaction front in microgravity is equal to the velocity which is characteristic to the purely reactiondiffusion-driven reaction front.

When the reaction was run in the so called open cells the behaviour of the reaction front was similar both regarding its velocity and shape. During hypergravity the front propagates with an increased velocity and reduced radius at the tip of it compared to normal gravitational conditions. However there is a significant difference in microgravity. The velocity of the chemical front is almost two times higher than it was measured in the closed cells. This shows the presence of Marangoni instability. The two instabilities therefore present simultaneously in the iodate-arsenous acid system in the cases where there is a liquid-gas interface. Nevertheless for a detailed investigation of the effect of Marangoni instability the quality and duration of microgravity has to be enhanced.

Further experiments were conducted on board of the MASER-13 suborbital sounding rocket. Based on the experience gained during the parabolic flights an experimental setup was applied in which pure Marangoni instability could be observed. The flight of the rocket provided six-minute long microgravity which had much higher quality compared to the parabolic flights. During the experiment beside recording the spatio-temporal characteristic of the reaction front, the generated fluid flow was also observed directly by means of particle image velocimetry (PIV) technique. Two transparent cuvette-like cells were used with different size in order to prove that the propagation of the reaction front is not induced by the gas-phase diffusion of iodine. It was experienced that the shape of the chemical front was only distorted by fluid flow which was only induced at the vicinity of the fluid-gas interface. This reactive borderline can be divided to two main sections by their orientation. One part has the same orientation as the platinum wires which were used for the initiation of the reaction while the other section is tilting to the direction of front propagation. By analysing 
the motion of the PIV particles individually, it was revealed that the significant fluid flow can only be observed in the vicinity of the fluid-gas interface. The fluid motion which occurs in the bulk has only a minor effect on the shape and motion of the front. The propagation of the reactive interface was fairly well reproduced by applying a geometric spreading model.

The spatio-temporal characteristics of the propagating front was observed only in two dimensions both during the parabolic flights and the sounding rocket experiment. In order to be able to reproduce the three-dimensional flow field fluid-dynamic calculations were done in the OpenFOAM software. A reaction-diffusion-advection model was created which solves the Navier-Stokes equations to reproduce the velocity and pressure fields on a three dimensional mesh. By applying the Boussinesq approximation the model includes the changes in density due to the change in composition and the induced fluid flow by the Rayleigh-Taylor instability can also be considered. The model can handle the autocatalytic reaction between iodate and arsenous acid only by applying the proper diffusion coefficients and by solving the differential equations with empirical rate coefficients which describe the reaction mechanism. If these properties available, other reactions can also be studied. The generated flow by Marangoni instability was modelled with the application of Marangoni boundary condition on the surface of the fluid domain.

The results of the numerical study showed good conformity regarding the two-dimensional shape of the reaction front. The velocity distribution of the flow generated by pure Marangoni instability shows that intense fluid motion only appears in the proximity of the fluid surface. The evolving convection ring has high asymmetry. The calculations provide the values of velocity, pressure and concentration field for the studied species in any arbitrary time. Therefore it is possible to reproduce the three-dimensional shape of the autocatalytic front. The concentration fields revealed that on the surface the front has a curved shape which is the characteristic shape of viscous laminar flow between rigid walls. By using the calculated velocity field the motion of virtual particles could be compared to the motion of the PIV particles. This comparison also showed good agreement. The model is a universally applicable model which allows to study the effect of instabilities which are occur in the iodate-arsenous acid reaction both in time and space. 


\section{Irodalomjegyzék}

[1] S. L. Miller, „A production of amino acids under possible primitive earth conditions”, Science, 117, 528-529 (1953).

[2] Jánosi T. I. és Tél T., Bevezetés a környezeti áramlások fizikájába: Légköri, óceáni folyamatok és éghajlati hatásaik (Typotex, Budapest, 2012).

[3] L. Lebreton, B. Slat, F. Ferrari, B. Sainte-Rose, J. Aitken, R. Marthouse, S. Hajbane, S. Cunsolo, A. Schwarz és A. Levivier, „Evidence that the Great Pacific Garbage Patch is rapidly accumulating plastic”, Sci. Rep., 8, 4666 (2018).

[4] J. Tóth, Gravitational systems of groundwater flow: theory, evaluation, utilization (Cambridge University Press, Cambridge, 2009).

[5] R. Mészáros, Á. Leelőssy, T. Kovács és I. Lagzi, „Predictability of the dispersion of Fukushima-derived radionuclides and their homogenization in the atmosphere", Sci. Rep., 6, 19915 (2016).

[6] https://upload.wikimedia.org/wikipedia/commons/6/65/

Cumulonimbus-incus_mykonos.jpg

https://marinedebris.noaa.gov/sites/default/files/GPmap_2012_ NOAAMDP . jpg

forráshelyek megtekintve: 2019-04-20.

[7] O. Reynolds, ,XXIX. An experimental investigation of the circumstances which determine whether the motion of water shall he direct or sinuous, and of the law of resistance in parallel channels", Phil. Trans. R. Soc., 174, 935-982 (1884).

[8] C. Normand, Y. Pomeau és M. Velarde, „Convective instability: A physicist's approach", Rev. Mod. Phys., 49, 581-624 (1977).

[9] J. E. Wesfreid, „Henri Bénard: Thermal convection and vortex shedding”, C. R. Mecanique, 345, 446-466 (2017).

[10] M. J. Block, „Surface tension as the cause of Bénard cells and surface deformation in a liquid film”, Nature, 178, 650 (1956).

[11] J. Pearson, „On convection cells induced by surface tension”, J. Fluid Mech., 4, 489500 (1958).

[12] D. A. Nield, „Surface tension and buoyancy effects in cellular convection”, J. Fluid Mech., 19, 341-352 (1964). 
[13] H. Bénard és D. Avsec, ,Travaux récents sur les tourbillons cellulaires et les tourbillons en bandes. Applications à l'astrophysique et à la météorologie", J. Phys. Radium, 9, 486-500 (1938).

[14] P. G. Saffman és G. I. Taylor, „The penetration of a fluid into a porous medium or HeleShaw cell containing a more viscous fluid", Proc. Roy. Soc. A, 245, 312-329 (1958).

[15] S. Hill, „Channeling in packed columns”, Chem. Eng. Sci., 1, 247-253 (1952).

[16] I. Brailovsky, A. Babchin, M. Frankel és G. Sivashinsky, „Fingering instability in wateroil displacement", Transport Porous Med., 63, 363-380 (2006).

[17] J. E. Garcia és K. Pruess, „Flow Instabilities During Injection of $\mathrm{CO}_{2}$ into SalineAquifers", Technical report, Ernest Orlando Lawrence Berkeley National Laboratory, Berkeley, CA (US) (2003).

[18] M. Czok, A. M. Katti és G. Guiochon, „Effect of sample viscosity in high-performance size-exclusion chromatography and its control", J. Chromatogr. A, 550, 705-719 (1991).

[19] R. A. Shalliker, H. J. Catchpoole, G. R. Dennis és G. Guiochon, „Visualising viscous fingering in chromatography columns: high viscosity solute plug", J. Chromatogr. A, 1142, 48-55 (2007).

[20] Lord Rayleigh, „Investigation of the character of the equilibrium of an incompressible heavy fluid of variable density", Proc. London Math. Soc., 14, 170-177 (1883).

[21] G. I. Taylor, „The instability of liquid surfaces when accelerated in a direction perpendicular to their planes, I.", Proc. Roy. Soc. A, 201, 192-196 (1950).

[22] D. J. Lewis, „The instability of liquid surfaces when accelerated in a direction perpendicular to their planes. II.", Proc. Roy. Soc. A, 202, 81-96 (1950).

[23] M. Roberts és J. Jacobs, „The effects of forced small-wavelength, finite-bandwidth initial perturbations and miscibility on the turbulent Rayleigh-Taylor instability", J. Fluid Mech., 787, 50-83 (2016).

[24] M. J. Andrews és S. B. Dalziel, „Small Atwood number Rayleigh-Taylor experiments”, Philos. Trans. Royal Soc. A, 368, 1663-1679 (2010).

[25] S. Iwasaki, Z. J. Luo, H. Kubota, T. Shibata, H. Okamoto és H. Ishimoto, „Characteristics of cirrus clouds in the tropical lower stratosphere”, Atmos. Res., 164, 358-368 (2015). 
[26] A. Cui és R. L. Street, „Large-eddy simulation of coastal upwelling flow”, Environ. Fluid Mech., 4, 197-223 (2004).

[27] R. Chevalier és T. Gull, „Outer structure of the Crab Nebula”, Astrophys. J., 200, 399401 (1975).

[28] X. Ribeyre, V. Tikhonchuk és S. Bouquet, „Compressible Rayleigh-Taylor instabilities in supernova remnants", Phys. Fluids, 16, 4661-4670 (2004).

[29] C. Marangoni, Sull'espansione delle goccie d'un liquido galleggianti sulla superfice di altro liquido, Ph.D. disszertáció (1865).

[30] J. Fournier és A. Cazabat, „Tears of wine”, Europhys. Lett., 20, 517 (1992).

[31] D. C. Venerus és D. N. Simavilla, „Tears of wine: New insights on an old phenomenon", Sci. Rep., 5, 16162 (2015).

[32] I. Langmuir, „Experiments with oil on water”, J. Chem. Educ., 8, 850 (1931).

[33] F. Wodlei és V. Pimienta, „Self-Organization of a Dichloromethane Droplet on the Surface of a Surfactant Containing Aqueous Solution”, „Italian Workshop on Artificial Life and Evolutionary Computation", 159-170 (Springer, 2015).

[34] T. Sutter, N. Kim, T. Kyu és D. Golovaty, „Crystal nucleation and motion in an undercooled binary solution", Curr. Opin. Chem. Eng., 7, 1-5 (2015).

[35] R. D. Deegan, O. Bakajin, T. F. Dupont, G. Huber, S. R. Nagel és T. A. Witten, „Capillary flow as the cause of ring stains from dried liquid drops”, Nature, 389, 827 (1997).

[36] H. Hu és R. G. Larson, „Marangoni effect reverses coffee-ring depositions”, J. Phys. Chem. B, 110, 7090-7094 (2006).

[37] R. Savino, D. Paterna és N. Favaloro, „Buoyancy and Marangoni effects in an evaporating drop", J. Thermophys. Heat Tr., 16, 562-574 (2002).

[38] D. Brutin, B. Sobac, B. Loquet és J. Sampol, „Pattern formation in drying drops of blood", J. Fluid Mech., 667, 85-95 (2011).

[39] D. Schwabe és A. Scharmann, „Some evidence for the existence and magnitude of a critical Marangoni number for the onset of oscillatory flow in crystal growth melts", J. Cryst. Growth, 46, 125-131 (1979).

[40] K. Showalter és J. J. Tyson, „Luther's 1906 discovery and analysis of chemical waves”, J. Chem. Educ., 64, 742 (1987). 
[41] G. Bazsa és I. R. Epstein, ,Traveling waves in the nitric acid-iron(II) reaction”, J. Phys. Chem., 89, 3050-3053 (1985).

[42] I. Nagypál, G. Bazsa és I. R. Epstein, „Gravity-induced anisotropies in chemical waves", J. Am. Chem. Soc., 108, 3635-3640 (1986).

[43] J. A. Pojman és I. R. Epstein, „Convective effects on chemical waves. 1. Mechanism and stability criteria", J. Phys. Chem., 94, 4966-4972 (1990).

[44] J. A. Pojman, I. P. Nagy és I. R. Epstein, „Convective effects on chemical waves. 3. Multicomponent convection in the iron(II)-nitric acid system", J. Phys. Chem., 95, 1306-1311 (1991).

[45] T. Bánsági Jr., D. Horváth és A. Tóth, „Multicomponent convection in the chloritetetrathionate reaction", Chem. Phys. Lett., 384, 153-156 (2004).

[46] L. Rongy, G. Schuszter, Z. Sinkó, T. Tóth, D. Horváth, A. Tóth és A. De Wit, „Influence of thermal effects on buoyancy-driven convection around autocatalytic chemical fronts propagating horizontally", Chaos, 19, 023110 (2009).

[47] G. Schuszter, G. Pótári, D. Horváth és Á. Tóth, „Three-dimensional convection-driven fronts of the exothermic chlorite-tetrathionate reaction", Chaos, 25, 064501 (2015).

[48] H. Miike, S. C. Müller és B. Hess, „Hydrodynamic flows traveling with chemical waves", Phys. Lett. A, 141, 25-30 (1989).

[49] K. Yoshikawa, T. Kusumi, M. Ukitsu és S. Nakata, „Generation of periodic force with oscillating chemical reaction”, Chem. Phys. Lett., 211, 211-213 (1993).

[50] K. Matthiessen, H. Wilke és S. C. Müller, „Influence of surface tension changes on hydrodynamic flow induced by traveling chemical waves", Phys. Rev. E, 53, 6056 (1996).

[51] K. Showalter, „Pattern formation in a ferroin-bromate system”, J. Chem. Phys., 73, 3735-3742 (1980).

[52] A. De Wit, K. Eckert és S. Kalliadasis, „Introduction to the focus issue: chemohydrodynamic patterns and instabilities”, Chaos, 22, 037101 (2012).

[53] L. Rongy és A. De Wit, „Steady Marangoni flow traveling with chemical fronts”, J. Chem. Phys., 124, 164705 (2006).

[54] L. Rongy és A. De Wit, „Marangoni flow around chemical fronts traveling in thin solution layers: influence of the liquid depth", J. Eng. Math., 59, 221-227 (2007). 
[55] R. A. Fisher, „The Wave of Advance of Advantageous Genes”, Ann. Eugenic., 7, 355369 (1937).

[56] S. Dushman, „The Rate of the Reaction between Iodic and Hydriodic Acids”, J. Phys. Chem., 8, 453-482 (1903).

[57] J. R. Roebuck, „The Rate of the Reaction between Arsenious Acid and Iodine in Acid Solutions; the Rate of the Reverse Reaction; and the Equilibrium between Them", J. Phys. Chem., 6, 365-398 (1901).

[58] N. Ganapathisubramanian és K. Showalter, „Comment on" A new iodate driven nonperiodic oscillatory reaction in a continuously stirred tank reactor"', J. Phys. Chem., 89, 2118-2119 (1985).

[59] A. Hanna, A. Saul és K. Showalter, „Detailed studies of propagating fronts in the iodate oxidation of arsenous acid", J. Am. Chem. Soc., 104, 3838-3844 (1982).

[60] J. A. Pojman, I. R. Epstein, T. J. McManus és K. Showalter, „Convective effects on chemical waves. 2. Simple convection in the iodate-arsenous acid system", J. Phys. Chem., 95, 1299-1306 (1991).

[61] J. Masere, D. A. Vasquez, B. F. Edwards, J. W. Wilder és K. Showalter, „Nonaxisymmetric and axisymmetric convection in propagating reaction-diffusion fronts", J. Phys. Chem., 98, 6505-6508 (1994).

[62] É. Pópity-Tóth, V. Pimienta, D. Horváth és Á. Tóth, „Hydrodynamic instability in the open system of the iodate-arsenous acid reaction”, J. Chem. Phys., 139, 164707 (2013).

[63] H. Dittus, „Drop tower 'Bremen': a weightlessness laboratory on Earth”, Endeavour, 15, 72-78 (1991).

[64] T. Könemann, U. Kaczmarczik, A. Gierse, A. Greif, T. Lutz, S. Mawn, J. Siemer, C. Eigenbrod, P. von Kampen és C. Lämmerzahl, „Concept for a next-generation drop tower system", Appl. Sci. Res., 55, 1728-1733 (2015).

[65] F. Haber és H. Haber, „Possible methods of producing the gravity-free state for medical research", J. aviat. Med, 21, 395-400 (1950).

[66] F. Karmali és M. Shelhamer, „The dynamics of parabolic flight: flight characteristics and passenger percepts", Acta Astronaut., 63, 594-602 (2008).

[67] B. Harvey és O. Zakutnyaya, Russian space probes: scientific discoveries and future missions (Springer Science \& Business Media, 2011). 
[68] „Lunar Science and Exploration - Apollo Missions”, https://www.lpi.usra.edu/ lunar/missions/apollo/, forráshelyek megtekintve: 2019-04-20.

[69] R. Sharpe és M. Wright, „Analysis of Microgravity Experiments Conducted on the Apollo Spacecraft", (2009).

[70] T. C. Bannister, „Heat flow and convection demonstration (Apollo 14)”, (1973).

[71] T. Bannister, P. Grodzka, L. Spradley, S. Bourgeois Jr, R. Hedden és B. Facemire, „Apollo 17 heat flow and convection experiments: Final data analyses results”, (1973).

[72] H. Kawamura, K. Nishino, S. Matsumoto és I. Ueno, „Report on microgravity experiments of Marangoni convection aboard international space station", J. Heat Transfer, 134, 031005 (2012).

[73] S. P. McKenna és W. R. McGillis, „Performance of digital image velocimetry processing techniques", Exp. Fluids., 32, 106-115 (2002).

[74] C. E. Willert és M. Gharib, „Digital particle image velocimetry”, Exp. Fluids., 10, 181-193 (1991).

[75] R. D. Keane és R. J. Adrian, „Theory of cross-correlation analysis of PIV images”, Appl. Sci. Res., 49, 191-215 (1992).

[76] I. F. Sbalzarini és P. Koumoutsakos, „Feature point tracking and trajectory analysis for video imaging in cell biology”, J. Struct. Biol, 151, 182-195 (2005).

[77] S. P. D. Spalding, „A calculation procedure for heat, mass and momentum transfer in three-dimensional parabolic flows", Int. J. Heat Mass Transf., 15 (1972).

[78] R. I. Issa, „Solution of the implicitly discretised fluid flow equations by operatorsplitting", J. Comput. Phys., 62, 40-65 (1986).

[79] A. C. Hindmarsh, P. N. Brown, K. E. Grant, S. L. Lee, R. Serban, D. E. Shumaker és C. S. Woodward, ,SUNDIALS: Suite of nonlinear and differential/algebraic equation solvers", ACM Trans. Math. Softw., 31, 363-396 (2005).

[80] R. Ramette és R. Sandford Jr, „Thermodynamics of iodine solubility and triiodide ion formation in water and in deuterium oxide", J. Am. Chem. Soc., 87, 5001-5005 (1965).

[81] I. R. Epstein és J. A. Pojman, An introduction to nonlinear chemical dynamics: oscillations, waves, patterns, and chaos (Oxford University Press, 1998).

[82] E. Pópity-Tóth, G. Pótári, I. Erdős, D. Horváth és A. Tóth, „Marangoni instability in the iodate-arsenous acid reaction front", J. Chem. Phys., 141, 044719 (2014). 


\section{Mellékletek}

A front terjedésének geometriai leírásához használt számítások Wolfram Mathematica (v 10.1) programban:

$1 \operatorname{tmin}\left[\mathrm{x}_{-}, \mathrm{z}_{-}, \mathrm{v} 0_{-}, \mathrm{vm}, \mathrm{L}_{-}\right]:=\operatorname{Min}[\mathrm{x} / \mathrm{v} 0, \mathrm{x} / \mathrm{vm}+(\mathrm{L}-\mathrm{z}) / \mathrm{vm}(\mathrm{v} 0 \wedge 2 /(\mathrm{vm}$ $\left.\wedge 2-\mathrm{v} 0 \wedge 2)\} \backslash \operatorname{verb}\left\{+\mathrm{vm} / \mathrm{v} 0 \operatorname{Sgrt}\left[\mathrm{v} 0 \wedge 2 /\left(\mathrm{vm}^{\wedge} 2-\mathrm{v} 0 \wedge 2\right)+1\right]\right)\right]$

2

$3 \mathrm{pos}=\{\}$

4

5 Do $[$ res=FindRoot $[\operatorname{tmin}[x, z, 0.03067,0.0635,10.0]==$ $14 * 14.85+29,\{x, 1.0\}]$;

6

$7 \operatorname{pos}=$ AppendTo[pos,$\{(x / 10 /$ res $),(10-z / 10)\}] ;,\{z, 0.0,10.0$, $0.01\}]$

A kód elsô sorában a tmin függvény és változóinak deffiniálása történik a (7.1) és a (7.4) egyenleteknek megfelelően. A második sorban a számított geometriai frontalakok adatait tartalmazó pos változót hozzuk létre. A harmadik sorban a mért sebességértékek megadásával számítjuk a minimalizált értékeket abban az idôpillanatban amelyben szeretnénk meghatározni a frontalakot.

Az OpenFOAM progrmacsomag PIMPLE megoldója kiegészítve a komponensek eloszlását számító CVODE kóddal

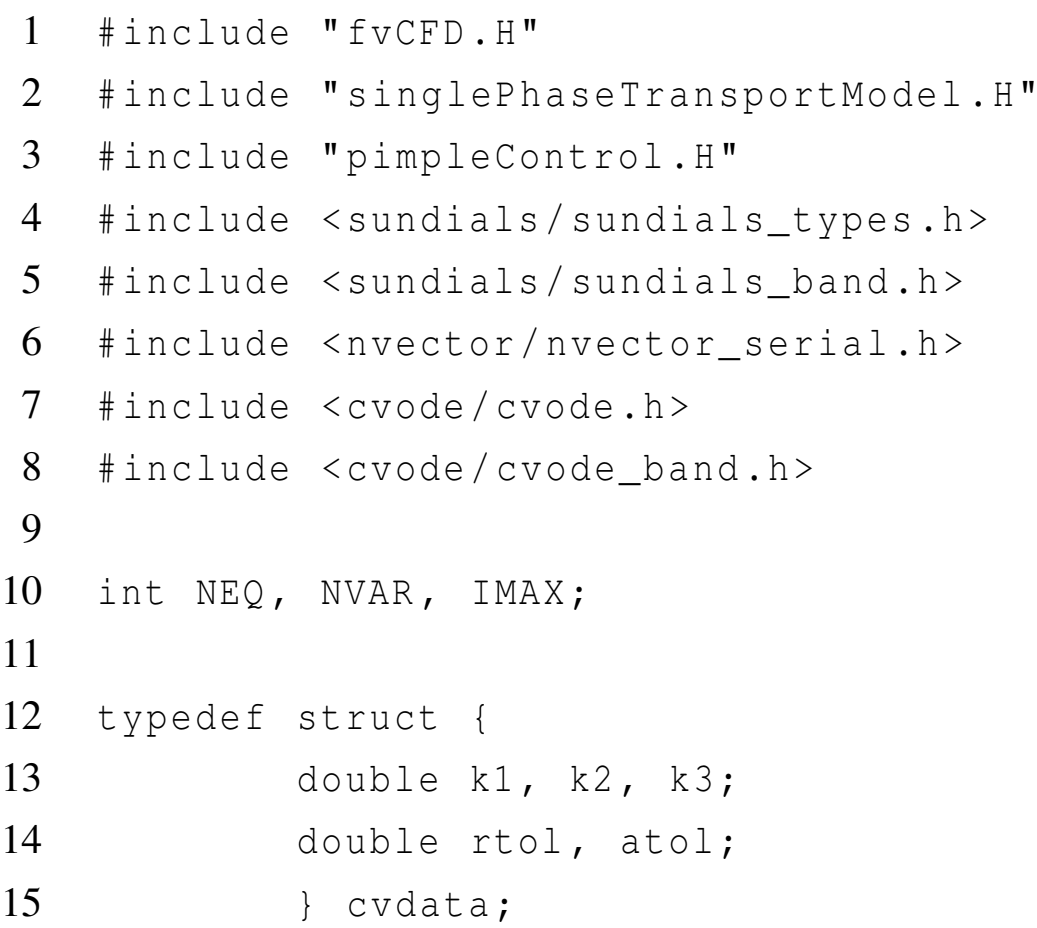




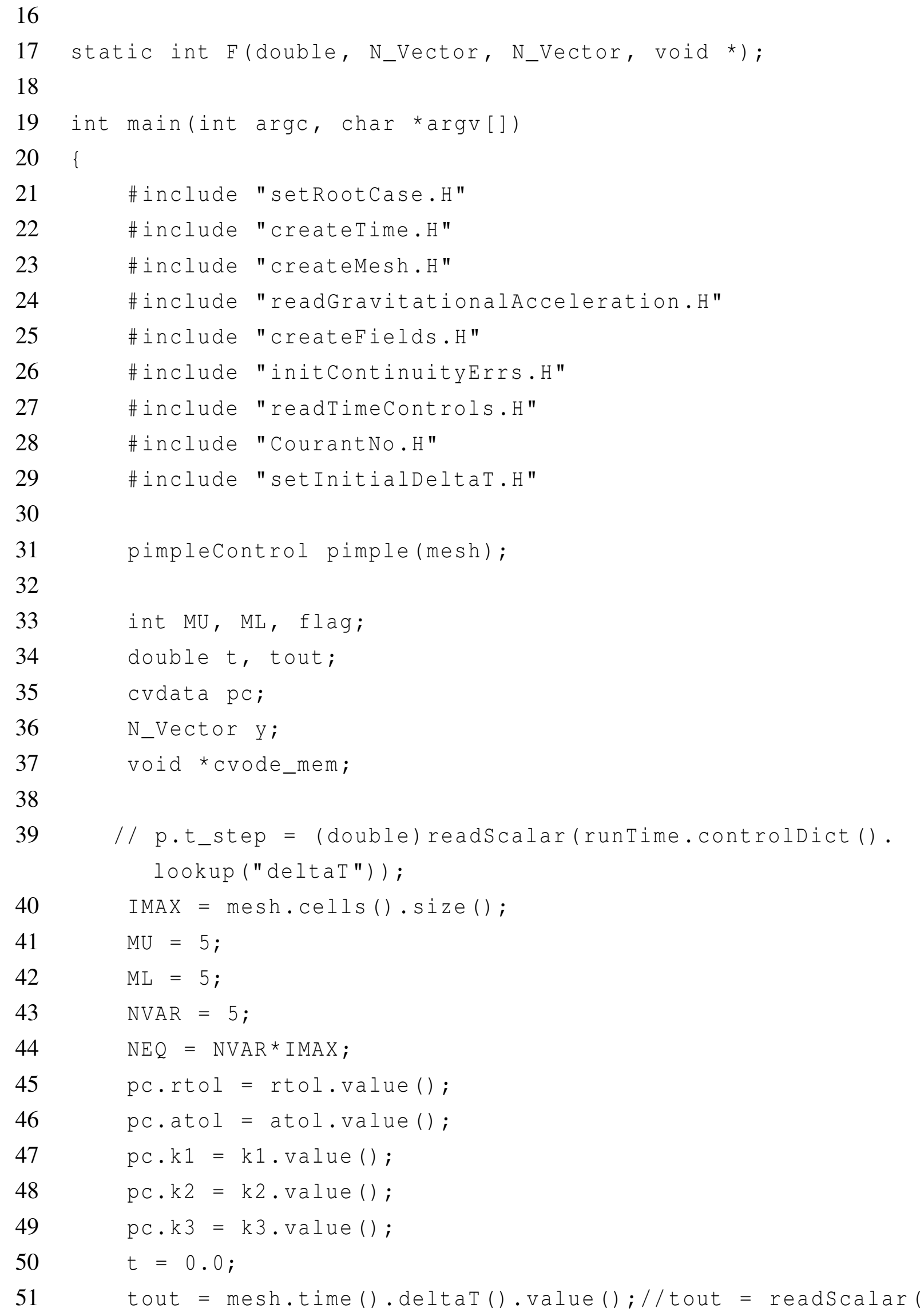


runTime.controldict (). lookup ("deltaT"));

52

53

54

55

56

57

58

59

60

61

62

63

64

65

66

67

68

69

70

71

72

73

74

75

76

77

78

79

80

81

82

83

84

85

86

87

Infor $<$ "npc.rtol = " $<$ pc.rtol $<$ endl;

Infor $<$ " Inpc.atol = " $<$ pc.atol $<$ endl;

Infor $<\backslash \mathrm{npc} \cdot \mathrm{kl}="<\mathrm{pc} \cdot \mathrm{k} 1<$ endl;

Infor $" \backslash \mathrm{npc} . \mathrm{k} 2="<\mathrm{pc} . \mathrm{k} 2<$ endl;

Infor "\npc.k3 = " $<$ pc.k3 $<$ endl;

Infor $<\backslash$ ntout $=$ " $<$ tout $<<$ endl;

Info $<$ " \nIMAX = " $<$ IMAX $<$ endl;

$\mathrm{y}=\mathrm{N}_{-}$VNew_Serial (NEQ);

CVode_mem=CVodeCreate $\left(\mathrm{CV}_{\text {_BDF }}, \mathrm{CV} \_\mathrm{NEWTON}\right)$;

flag=CVodeInit (cvode_mem, F, t , y) ;

flag=CVodesstolerances (cvode_mem, pc.rtol,pc.atol);

flag =CVodeSetUserData ( cvode_mem, (void *)\&pc);

flag=CVodeSetMaxNumSteps (cvode_mem, mxstep.value ()) ;

flag=CVodeSetMaxStep (cvode_mem, hmax.value () ) ;

$\mathrm{flag}=$ CVBand ( cvode_mem, NEQ, MU, ML ) ;

Infor $" \backslash$ nStarting time loop \n" $<<$ endl;

while (runtime.loop ())

Infor $<$ Time $="<$ runTime.timeName () $<$ nl $<$ endl;

\#include "readTimecontrols.H"

\#include "CourantNo.H"

\#include "setDeltaT.H"

// --- Pressure-velocity PIMPLE corrector loop

while (pimple.loop ())

// Solve the momentum equation 


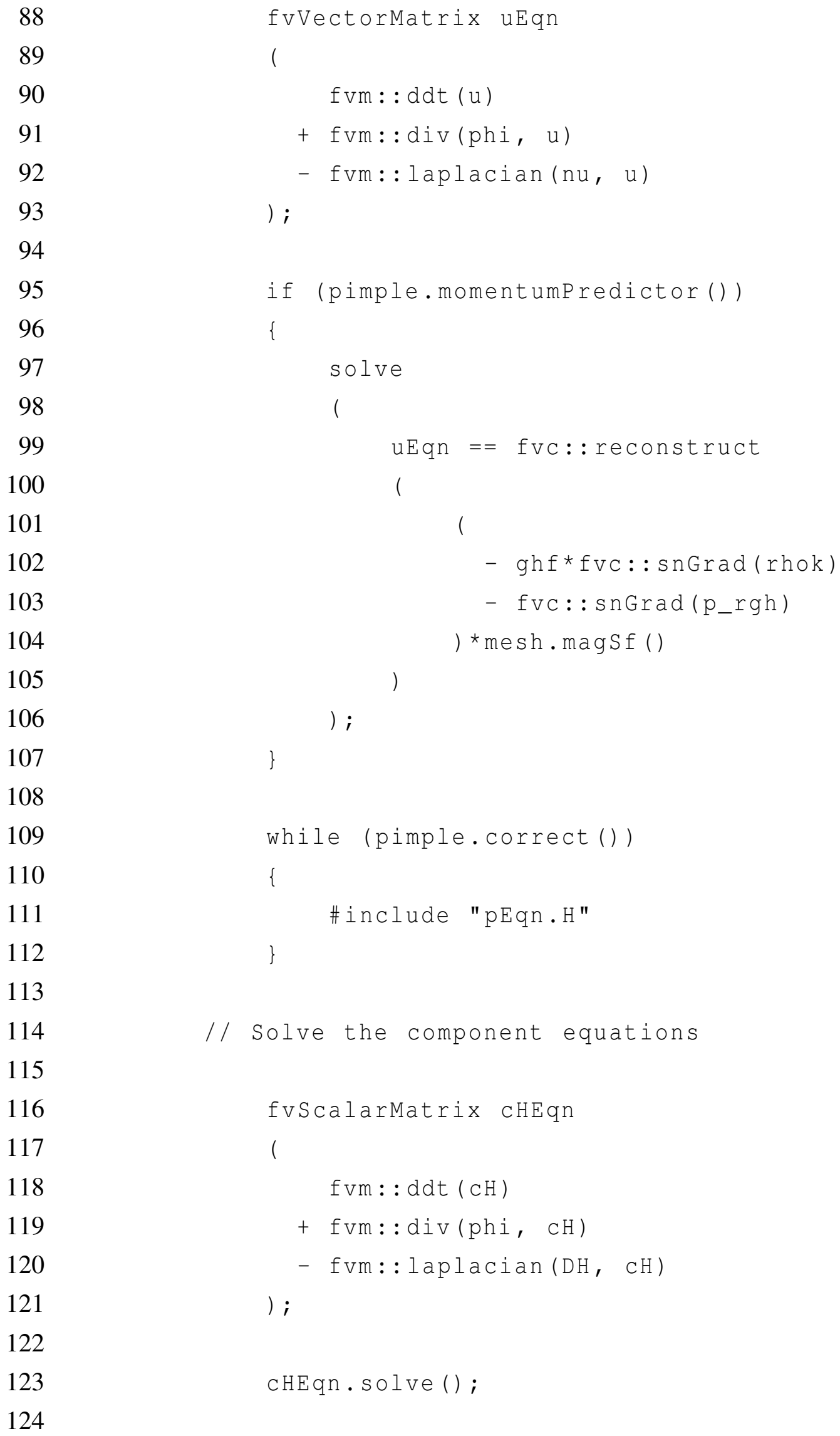




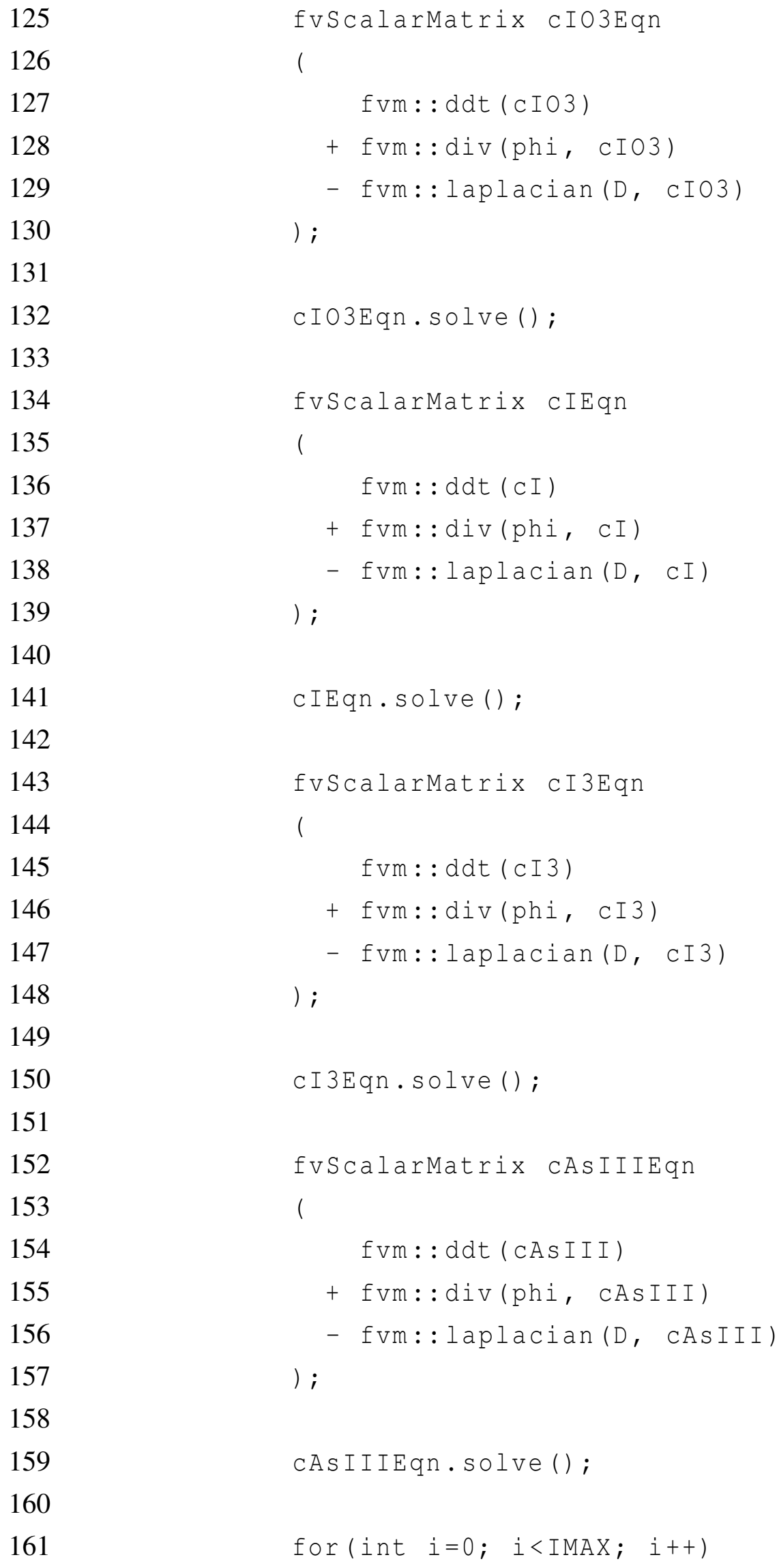

161 
162

163

164

165

166

167

168

169

170

171

172

173

174

175

176

177

178

179

180

181

182

183

184

185

186

187

188

189

190

191

192

193

194

195

196

NV_Ith_S $(y, i * N V A R)=c H[i] ; / / c H . i n t e r n a l F i e l d$

( ) [i];

NV_Ith_S $(y, i * N V A R+1)=$ CIO3 [i];

NV_Ith_S $(y, i * N V A R+2)=C I[i] ;$

NV_Ith_S $(y, i * N V A R+3)=$ cI3 [i];

NV_Ith_S $(y, i * N V A R+4)=$ CASIII $[1]$;

\}

flag=CVodeReInit (cvode_mem, t, y) ;

flag=CVode (cvode_mem, tout,y, \&t, CV_NORMAL) ;

tout $+=$ mesh.time().deltaT().value ();

Infor $<\backslash$ ntout $(2)="<$ tout $<$ endl;

for (int $i=0 ; i<\operatorname{IMAX} ; i++)$

\{

$\mathrm{CH}[\mathrm{i}]=\mathrm{NV}_{-}$Ith_S $(\mathrm{y}, \mathrm{i} * \mathrm{NVAR})$;

CIO3 [i] = NV_Ith_S $(y, i * N V A R+1)$;

CI $[i]=N_{-} I t h \_S(y, i * N V A R+2)$;

CI3 [i] = NV_Ith_S $(y, i * N V A R+3)$;

CASIIIi] = NV_Ith_S $(y, i * N V A R+4)$;

\}

$\mathrm{CASV}=(\mathrm{COAS}-\mathrm{CASIII}) ;$

/ / arzensav

CI2 $=\mathrm{CI} 3 /\left(\mathrm{KI} 3 *_{\mathrm{CI}}\right)$;

rhok $=1.0+k{ }^{*}\left(\right.$ rhoIO $3{ }^{*} \mathrm{CIO} 3+$ rhoI*CI + rhoI $3{ }^{*} \mathrm{CI} 3$

+ rhoAsIII*CASII + rhoAsV*CAsV);

gradc $=$ fvc: : grad (cI2);

\}

runtime.write ();

Infor "ExecutionTime = " < runtime.elapsedCpuTime() 


$$
<\text { " S " }
$$$$
<\quad " \text { ClockTime }="<\text { runTime.elapsedClockTime() }
$$$$
<<\text { " S " }
$$

198

$<\mathrm{nl}<<$ endl;

199

200

201

Infor $<$ End $\backslash n "<$ endl;

202

203

CVodeFree (\&Cvode_mem);

204 N_VDestroy_Serial (y) ;

205

206

return 0 ;

207

208

209

static int F(double t, N_Vector y, N_Vector ydot, void *

$$
\text { f_data) \{ }
$$

210

211 int $j$;

212 double rs[2], cH, cIO3, cI, cI3, cAsII;

213 crdata * $p$;

214

215

216 for $(j=0 ; j<N E Q ; j+=N V A R) \quad\{$

$217 \quad \mathrm{CH}=\mathrm{NV}$ Ith_S $(y, j+0)$;

218

219

220

221

222

223

$$
\text { CIO3=NV_Ith_S }(y, j+1) \text {; }
$$

224

CI $=N_{-}$Ith_S $(y, j+2)$;

225

226

227

cI3 $=$ NV_Ith_S $(y, j+3)$;

228

$$
\text { CASIII }=N_{-} \text {Ith_S }(y, j+4) \text {; }
$$

229

$$
\text { rs }[0]=((p->k 1)+(p->k 2) * C I) * C I O 3 * C I * C H * C H \text {; }
$$

230 rs $[1]=(p->k 3) * c I 3 * c A S I I /(c I * c I * c H)$;

5

26

$$
\text { NV_Ith_S }(y d o t, j+0)=-6 * r s[0]+3 * r s[1] ;
$$$$
\text { NV_Ith_S }(y d o t, j+1)=-r s[0] \text {; }
$$

28

$$
\begin{aligned}
& \text { NV_Ith_S }(y d o t, j+2)=-8 * r s[0]+3 * r s[1] ; \\
& N V_{-} \text {Ith_S }(y d o t, j+3)=3 * r s[0]-r s[1] ;
\end{aligned}
$$

NV_Ith_S $(y d o t, j+4)=-r s[1]$; 
231

232

return (0); 


\section{Köszönetnyilvánítás}

Ez úton szeretnék köszönetet mondani az SZTE Nemlineáris Dinamika és Kinetika csoport vezetőinek Dr. Tóth Ágotának és Dr. Horváth Dezsőnek azért, hogy helyet biztosítottak számomra a kutatócsoportban. Hálás vagyok az általuk belém és munkámba fektetett időért, energiáért és azért, hogy biztosították azt a forrást, amely nélkül kutatásom nem lehetett volna teljes. Az általuk támasztott elvárások a minőségi munkára való törekvés új dimenzióját nyitották ki előttem. Örömmel gondolok vissza a Fizikai Kémiai és Anyagtudományi tanszéken eltöltött évekre, melyeket az ott dolgozó kutatók és hallgatók által biztosított jó légkör színesített.

Köszönet illeti az Európai Û́rügynökséget azért a nyújtott támogatásért, aminek keretein belül kísérleti munkámat professzionális és világszínvonalú körülmények között végezhettem Bordeauxban és Esrange űrközpontban. Köszönettel tartozom Dr. Szanyi Jánosnak, aki nélkül nem kezdhettem volna el doktori tanulmányaimat és az Ásványtani, Geokémiai és Kőzettani tanszék munkatársainak. Az itt eltöltött évek is meghatározó szerepet játszottak szakmai gondolkodásom formálásában!

Hálával tartozom szüleimnek az értem tett összes erőfeszítésükért és végtelen türelmükért. Önfeláldozó munkájuknak köszönhetem, hogy mindig olyan légkört teremtettek otthonunkban, amely a munkámban való pozitív érvényesülést segítette. Végül, de nem utolsó sorban büszkeséggel tölt el ahogy párommal, Tóth-Szeles Eszterrel kitartással, együttérzéssel és türelemmel támogattuk egymást a nehezebb időszakokon való túllendülésben a disszertációinkra áldozott időkben. 